DOE/OR-1001

\title{
Oak Ridge Reservation Site Management Plan for the Environmental Restoration Program
}

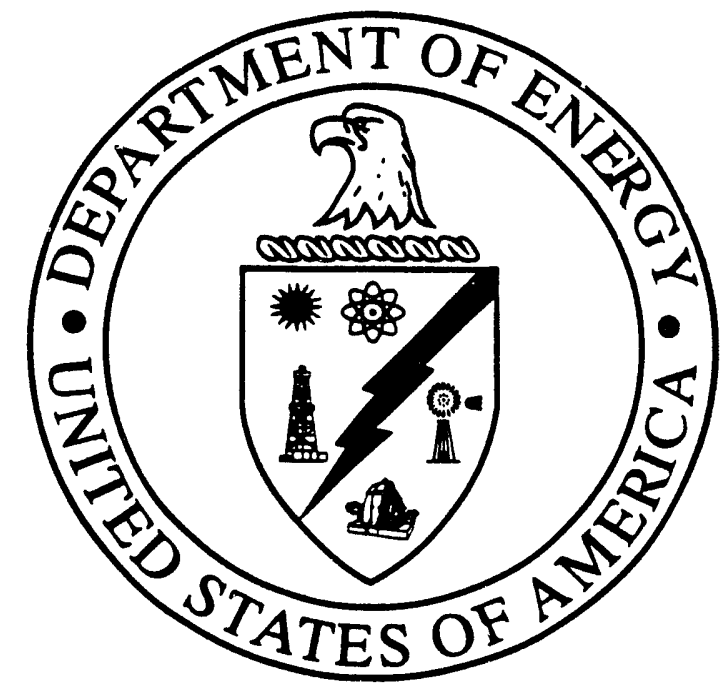

$\operatorname{coc} \cap 31991$ 
This report has been reproduced directly from the best available copy.

Available to DOE and DOE contractors from the Office of Scientific and Technical Information, P.O. Box 62, Oak Ridge, TN 37831; prices available from 615-576-8401, FTS 626-8401.

Avallable to the public from the National Technical Information Service, U.S. Department of Commerce, 5285 Port Royal Rd., Springfield, VA 22161. 


\title{
Oak Ridge Reservation Site Management Plan for the Environmental Restoration Program
}

\author{
Environmental Restoration Division \\ P.O. Box 2003 \\ Oak Ridge, Tennessee 37831-7298
}

Date Issued-September 1991

\section{Prepared for}

U.S. Department of Energy

Office of Environmental Restoration and Waste Management under budget and reporting code EW 20

MARTIN MARIETTA ENERGY SYSTEMS, INC.

$$
\text { managing the }
$$

Oak Ridge National Laboratory

Oak Ridge K-25 Site
Oak Ridge Y-12 Plant

Paducah Gaseous Diffusion Plant

under contract DE-AC05-84OR21400

and the

Portsmouth Gaseous Diffusion Plant under contract DE-AC05-76OR00001

for the

U.S. DEPARTMENT OF ENERGY 


\section{CONTENTS}

FIGURES $\ldots \ldots \ldots \ldots \ldots \ldots \ldots \ldots \ldots \ldots \ldots \ldots \ldots \ldots \ldots \ldots \ldots$ vii

ACRONYMS $\ldots \ldots \ldots \ldots \ldots \ldots \ldots \ldots \ldots \ldots \ldots \ldots \ldots \ldots \ldots \ldots \ldots \ldots$

1. INTRODUCTION $\ldots \ldots \ldots \ldots \ldots \ldots \ldots \ldots \ldots \ldots \ldots \ldots \ldots \ldots$

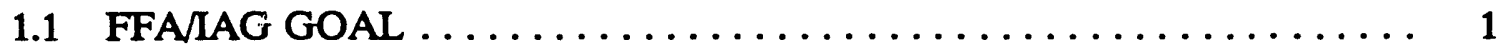

1.2 SITE MANAGEMENT PLAN GOAL $\ldots \ldots \ldots \ldots \ldots \ldots \ldots \ldots \ldots \ldots \ldots$

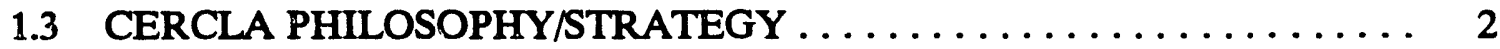

1.4 PROGRAM INTEGRATION INTO CERCLA $\ldots \ldots \ldots \ldots \ldots \ldots \ldots \ldots$

1.4.1 RCRA integration into CERCLA ................ 3

1.4.2 Integration of Other Programs into the CERCLA Process $\ldots \ldots \ldots .5$

2. CERCLA PROCESS ........................ 6

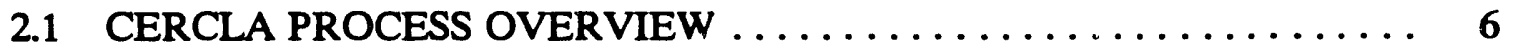

2.2 PRELIMINARY ASSESSMENT/SITE INSPECTION $\ldots \ldots \ldots \ldots \ldots \ldots 6$

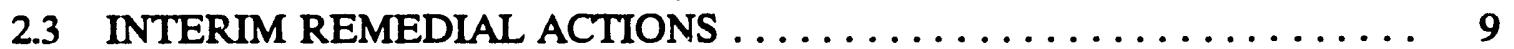

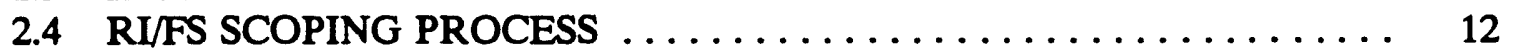

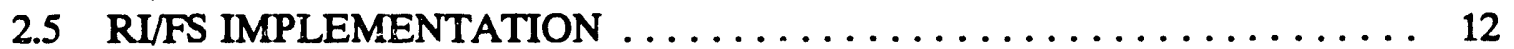

2.6 REVIEW/DECISION PROCESS $\ldots \ldots \ldots \ldots \ldots \ldots \ldots \ldots \ldots \ldots \ldots \ldots \ldots$

2.7 ROD SCHEDULE $\ldots \ldots \ldots \ldots \ldots \ldots \ldots \ldots \ldots \ldots \ldots \ldots \ldots \ldots \ldots \ldots \ldots$

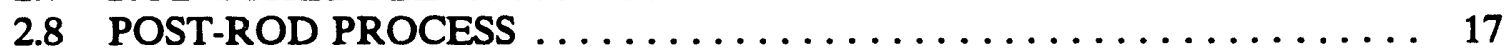

2.9 REMEDIAL DESIGN PROCESS $\ldots \ldots \ldots \ldots \ldots \ldots \ldots \ldots \ldots \ldots \ldots \ldots \ldots$

2.10 REMEDIAL ACTION PROCESS $\ldots \ldots \ldots \ldots \ldots \ldots \ldots \ldots \ldots \ldots \ldots \ldots$

2.11 POSTREMEDIATION MONITORING ................. 19

3. OU/STUDY AREA CONCEPT AND OU DESCRIPTION $\ldots \ldots \ldots \ldots \ldots$

3.1 OAK RIDGE NATIONAL LABORATORY WAGs/OUs . . . . . . . . . 20

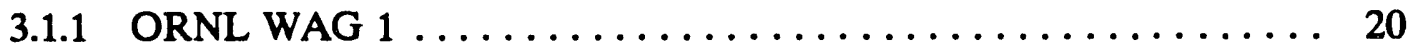

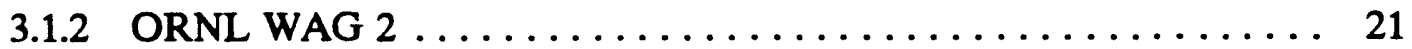

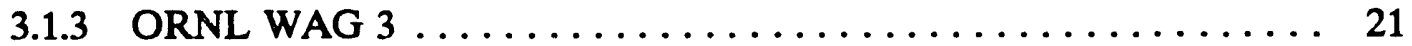

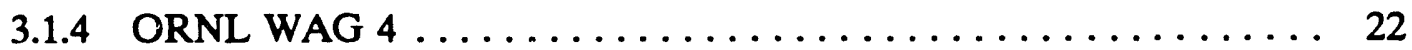

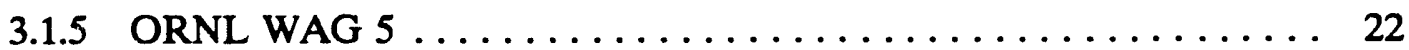

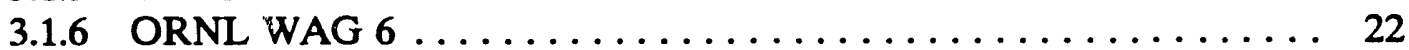

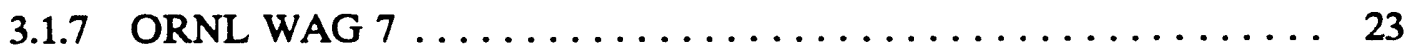

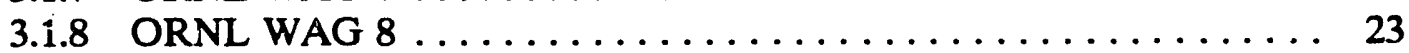

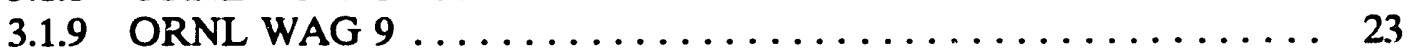

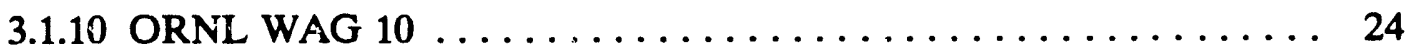

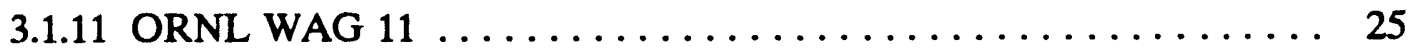

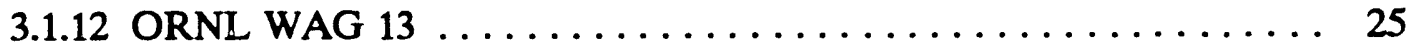

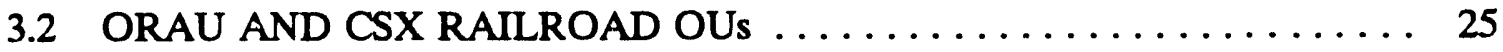

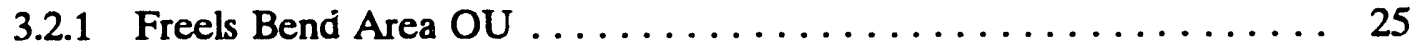

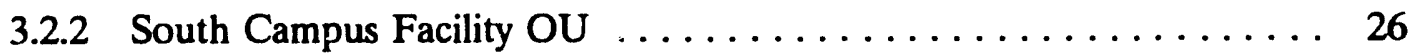

3.2 .3 CSX Railroad OU ....................... 26 


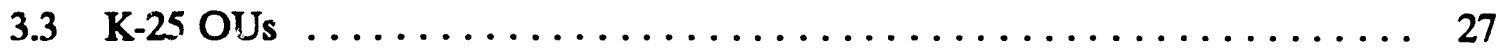

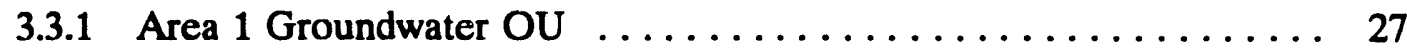

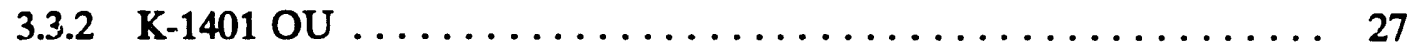

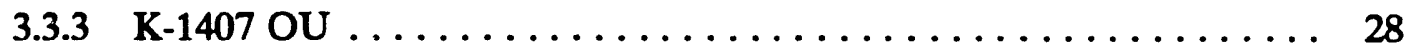

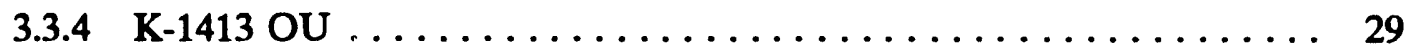

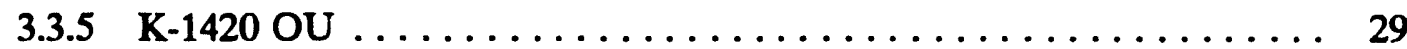

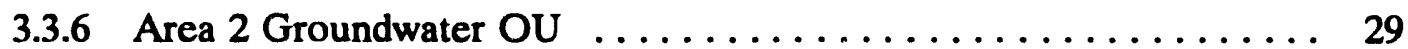

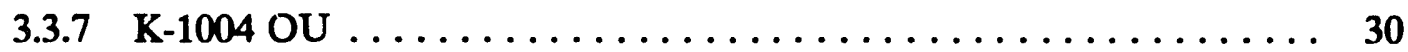

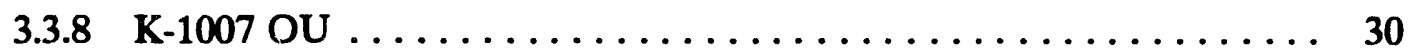

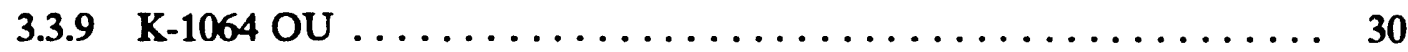

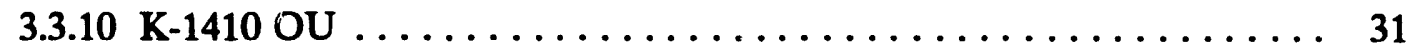

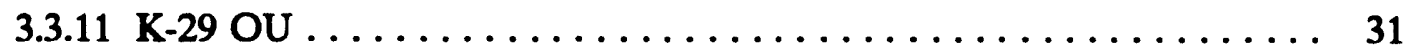

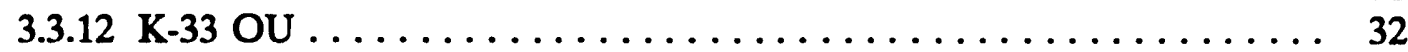

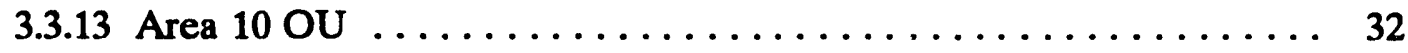

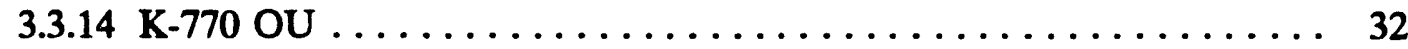

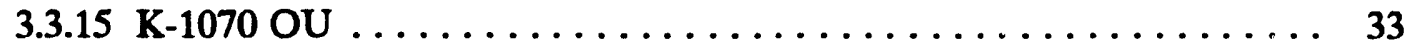

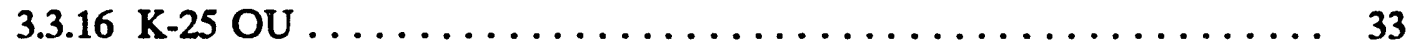

3.3.17 K-1417 Drum Storage Area .................. 33

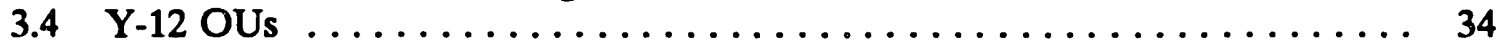

3.4.1 Upper East Fork Poplar Creek OU $1 \ldots \ldots \ldots \ldots \ldots \ldots \ldots$

3.4 .2 Upper East Fork Poplar Creek OU $2 \ldots \ldots \ldots \ldots \ldots \ldots \ldots \ldots$

3.4 .3 Upper East Fork Poplar Creek OU $3 \ldots \ldots \ldots \ldots \ldots \ldots \ldots \ldots$

3.4.4 Upper East Fork Poplar Creek OU $4 \ldots \ldots \ldots \ldots \ldots \ldots \ldots \ldots \ldots$

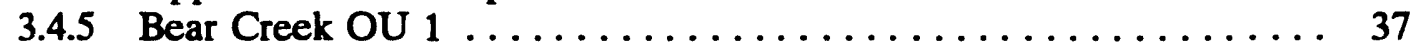

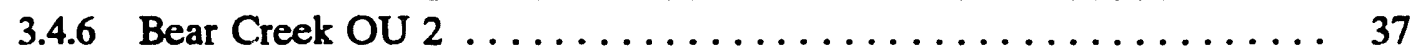

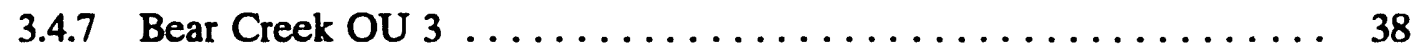

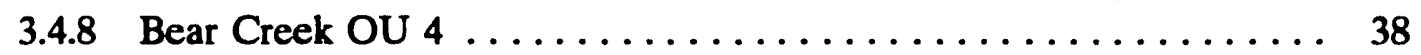

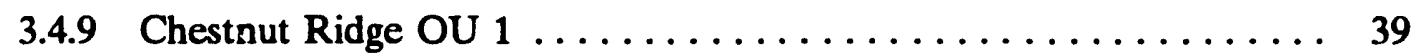

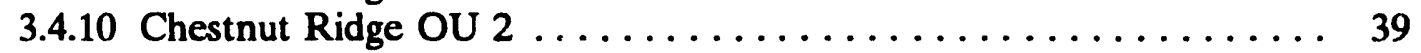

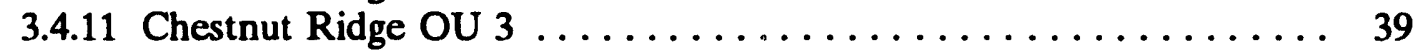

3.4.12 East Fork Poplar Creek OU .................. 39

3.5 CLINCH RIVER OU ....................... 40

4. PROGRAMMATIC UNITS $\ldots \ldots \ldots \ldots \ldots \ldots \ldots \ldots \ldots \ldots \ldots \ldots \ldots$

4.1 ORR DECONTAMINATION AND DECOMMISSIONING (D\&D)

PROGRAM $\ldots \ldots \ldots \ldots \ldots \ldots \ldots \ldots \ldots \ldots \ldots \ldots \ldots \ldots \ldots$

4.2 WASTE MANAGEMENT PROGRAM $\ldots \ldots \ldots \ldots \ldots \ldots \ldots \ldots \ldots$

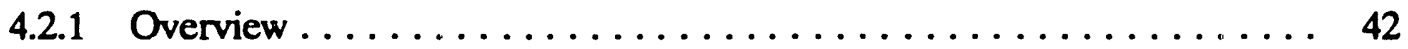

4.2 .2 Information Management $\ldots \ldots \ldots \ldots \ldots \ldots \ldots \ldots \ldots \ldots \ldots \ldots$

4.2.3 Waste Management Funding and Responsibilities ........... 43

4.2 .4 TSD Capacity and Future Impacts ................. 43

4.2.5 Management of Investigation-Derived Wastes ........... 43

4.3 RESERVATION GROUNDWATER PROGRAM . . . . . . . . . . 44

4.3.1 General Description of the Groundwater Program ........... 44

4.3.2 Activities To Be Performed .................. 45

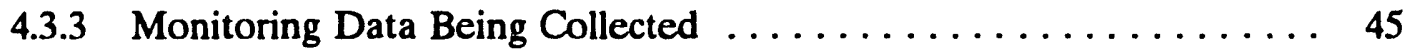

4.3 .4 Future Activities . . . . . . . . . . . . . . . . . 46

4.4 WELL PLUGGING AND ABANDONMENT PROGRAM . . . . . . 46 
4.5 ANALYTICAL LABORATORIES PROGRAM . . . . . . . . . . . . 47

4.6 ENVIRONMENTAL DATA MANAGEMENT PROGRAM $\ldots \ldots \ldots \ldots .48$

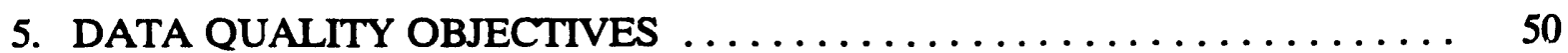

5.1 DQOs AND SAMPLE COLLECTION $\ldots \ldots \ldots \ldots \ldots \ldots \ldots \ldots \ldots \ldots \ldots$

5.2 DQOs AND SAMPLE ANALYSES $\ldots \ldots \ldots \ldots \ldots \ldots \ldots \ldots \ldots \ldots \ldots \ldots$

5.3 DQOs AND DATA EVALUATION .................. 50

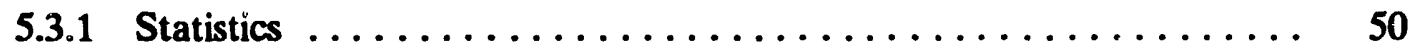

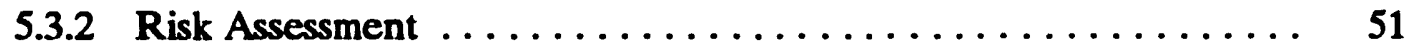

6. PRIORITIZATION $\ldots \ldots \ldots \ldots \ldots \ldots \ldots \ldots \ldots \ldots \ldots \ldots \ldots \ldots \ldots$

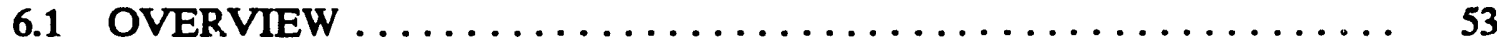

6.2 PRIORITIZATION PROCESS $\ldots \ldots \ldots \ldots \ldots \ldots \ldots \ldots \ldots \ldots \ldots \ldots \ldots$

7. PROGRAM MANAGEMENT $\ldots \ldots \ldots \ldots \ldots \ldots \ldots \ldots \ldots \ldots \ldots$

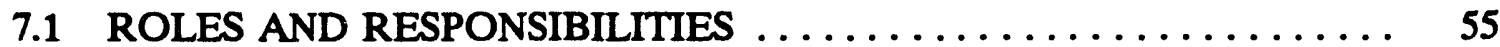

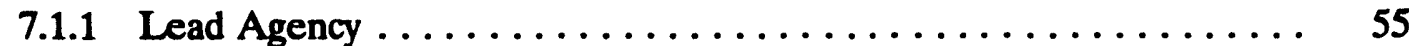

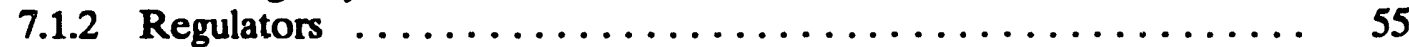

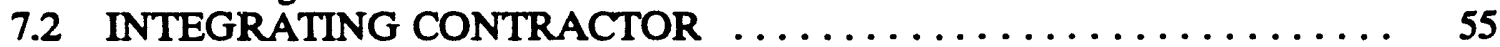

7.3 WORKING SESSIONS AND RA PROGRAM MEETINGS ....... 57

7.3.1 Working Sessions ......................... 57

7.3.2 RA Program Meetings $\ldots \ldots \ldots \ldots \ldots \ldots \ldots \ldots \ldots \ldots \ldots$

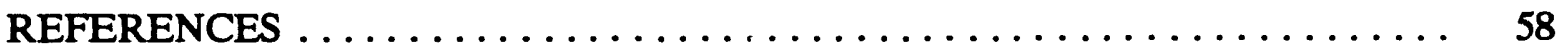

Appendix A. RCRA/CERCLA SCHEDULE LOGIC $\ldots \ldots \ldots \ldots \ldots \ldots \ldots \ldots$ A-1

Appendix B. NO FURTHER ACTION DETERMINATION $\ldots \ldots \ldots \ldots \ldots \ldots$ B-1

Appendix C. OPERABLE UNIT LIFE-CYCLE SCHEDULES $\ldots \ldots \ldots \ldots \ldots \ldots$ C-1

Appendix D. MAPS OF OAK RIDGE RESERVATION OPERABLE UNITS . . . D-1

Appendix E. OAK RIDGE RESERVATION OPERABLE UNITS $\ldots \ldots \ldots \ldots$ E-1 


\section{FIGURES}

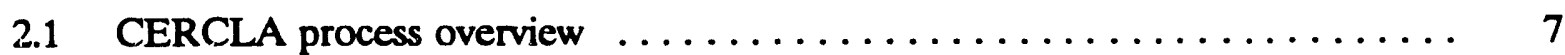

2.2 Schedule of the generic CERCLA process for the ORR $\ldots \ldots \ldots \ldots \ldots$. 8

2.3 Preliminary assessment/site inspection process $\ldots \ldots \ldots \ldots \ldots \ldots \ldots \ldots, 10$

2.4 Flowchart depicting interim remedial actions process $\ldots \ldots \ldots \ldots \ldots \ldots, 11$

2.5 Generic flowchart showing RI/FS implementation process $\ldots \ldots \ldots \ldots \ldots, 13$

2.6 Document review process specified by the Agreement $\ldots \ldots \ldots \ldots \ldots \ldots, 15$

2.7 The decision process for FFA/IAG documents $\ldots \ldots \ldots \ldots \ldots \ldots \ldots \ldots, 16$

2.8 The post-ROD process $\ldots \ldots \ldots \ldots \ldots \ldots \ldots \ldots \ldots \ldots \ldots \ldots \ldots, 18$

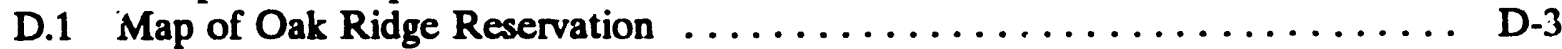

D.2 Map showing Oak Ridge National Laboratory operable units $\ldots \ldots \ldots \ldots$ D-5

D.3 Map showing Freels Bend area and South Campus Facility

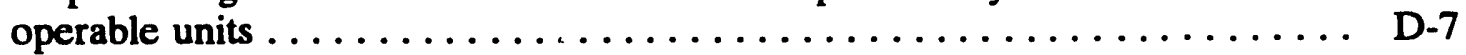

D.4 Map showing CSX Railroad operable unit $\ldots \ldots \ldots \ldots \ldots \ldots \ldots \ldots$ D-9

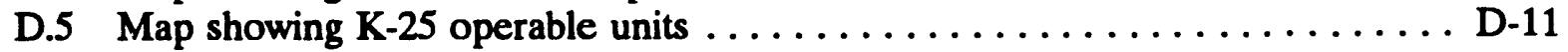

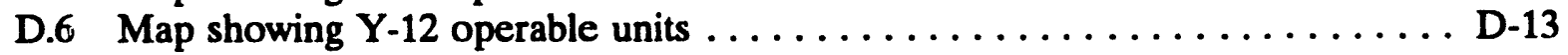

D.7 Map showing Bear Creek operable units 3 and 4 and Upper East Fork Poplar Creek operable unit $4 \ldots \ldots \ldots \ldots \ldots \ldots \ldots$ D-15

D.8 Map showing Lower East Fork Poplar Creek and Sewer

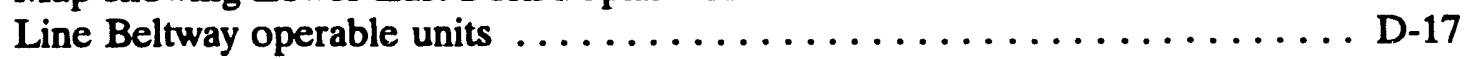

D.9 Map showing Clinch River operable unit $\ldots \ldots \ldots \ldots \ldots \ldots \ldots \ldots \ldots \ldots \ldots \ldots \ldots$ 


\section{ACRONYMS}

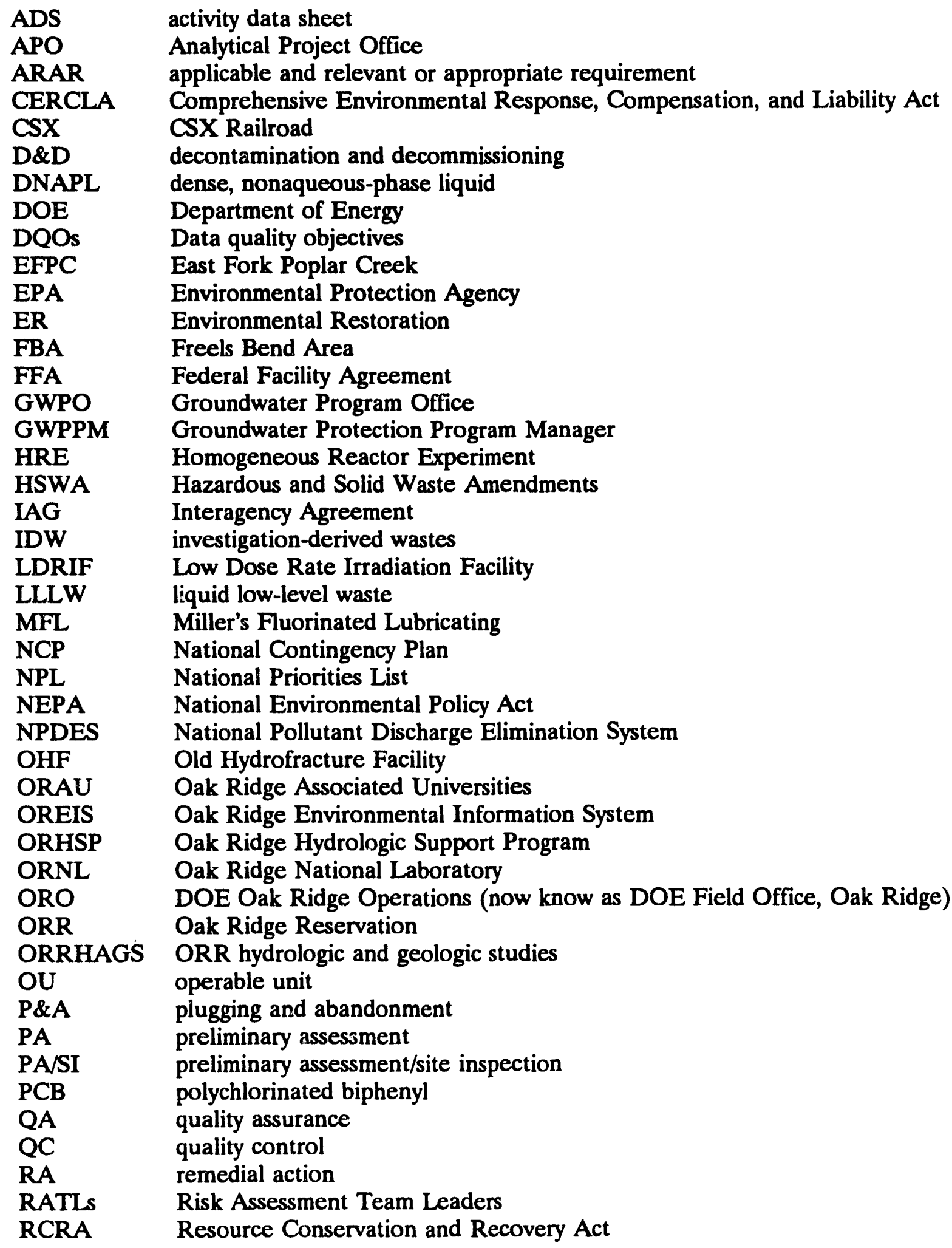




$\begin{array}{ll}\text { RCW } & \text { recirculating cooling water } \\ \text { RD } & \text { remedial design } \\ \text { RFI } & \text { RCRA Facility Investigation } \\ \text { RI } & \text { remedial investigation } \\ \text { RIFS } & \text { remedial investigation/feasibility study } \\ \text { ROD } & \text { Record of Decision } \\ \text { SCF } & \text { South Campus Facilities } \\ \text { SI } & \text { site inspectiun } \\ \text { SWMU } & \text { solid waste management unit } \\ \text { SWSA } & \text { solid waste storage area } \\ \text { TAL } & \text { target analyte list } \\ \text { TCL } & \text { target compound list } \\ \text { TDEC } & \text { Tennessee Department of Environment and Conservation } \\ \text { TSD } & \text { treatment, storage, and disposal } \\ \text { TRU } & \text { transuranics } \\ \text { UNC } & \text { United Nuclear Corporation } \\ \text { VDRIF } & \text { Variable Dose Rate Irradiation Facility } \\ \text { VOC } & \text { volatile organic compound } \\ \text { WAG } & \text { waste area grouping } \\ \text { WM } & \text { Waste Management } \\ \text { WOC } & \text { White Oak Creek } \\ \text { WOL } & \text { White Oak Lake }\end{array}$




\section{INTRODUCTION}

This site management plan for the Environmental Restoration (ER) Program implements the Oak Ridge Reservation (ORR) Federal Facility Agreement (FFA) (EPA 1990), also known as an Interagency Agreement (IAG), hereafter referred to as "the Agreement." The Department of Energy (DOE), the U.S. Environmental Protection Agency (EPA), a.7d the Tennessee Department of Environment and Conservation (TDEC), hereafter known as "the Parties," entered into this Agreement for the purpose of coordinating remediation activities undertaken on the ORR to comply with the Comprehensive Environmental Response, Compensation, and Liability Act (CERCLA) as amended by the Superfund Amendments, the Resource Conservation and Recovery Act (RCRA), and the National Environmental Policy Act (NEPA).

\subsection{FFAMAG GOAL}

The Parties have a common goal that the actions taken under the Agreement are reasonable and necessary to ensure that the environmental impacts associated with past and present activities pertaining to remediation at the ORR are thoroughly investigated and that appropriate remedial action (RA) is taken to protect human health and the environment.

The general purposes of the Agreement are to

- Establish a procedural framework and schedule for developing, implementing, and monitoring appropriate response actions at the ORR in accordance with CERCLA, RCRA, NEPA, appropriate guidance and policy, and Tennessee state law.

- Coordinate response actions under CERCLA and this Agreement with RCRA Facility Investigations (RFIs) and corrective measures now being conducted under RCRA and applicable state laws.

- Minimize the duplication of investigative and analytical work and documentation and ensure the quality of data management.

- Expedite response actions with a minimum of delay.

\subsection{SITE MANAGEMENT PLAN GOAL}

This site management plan has been prepared to describe the overall approach being used to address environmental contamination problems at the ORR, located in eastern Tennessee. The ORR is made up of three major DOE installations constructed in the early to mid 1940 s as research, development, and process facilities in support of the Manhattan Project. In addition to the three installations-Oak Ridge National Laboratory (ORNL), Oak Ridge Y-12 Nuclear Weapons Plant, and the former Oak Ridge Gaseous Diffusion Plant (now officially called the Oak Ridge K-25 Site)-the ORR also contains areas outside the 
installations-land used by the Oak Ridge Associated Universities (ORAU) and waterways that may have been adversely affected by contaminated releases from the installations.

To achieve remediation of the ORR as a whole, the Parties have partitioned the ORR into waste area groupings (WAGs)/operable units (OUs), which can be prioritized to achieve the most effective and rapid investigation and cleanup possible. The goal of this plan is to describe the rational basis for addressing these OUs, which includes defining the OUs and their interrelationships based on existing information and the working relationship with the regulators and the public. This will allow for the redefining and consolidation of these OUs as additional investigation activities are performed.

The following activities are basic to the ORR planning effort:

- Emphasis is placed on integrating ongoing activities and historical information into the overall effort.

- Considerable attention and importance has been paid to coordinating and integrating the activities of other major programs with the ER Program in order to ensure that adequate resources are available, data are provided in a consistent format to satisfy multiprogram needs, and technical issues and remediation technologies are communicated throughout the ER Program so that consistent approaches are applied.

- RA schedules for the OUs are dynamic and can be revised per mutual agreement of the Parties and appropriate public involvement.

- OUs may be redefined or reprioritized as the investigation progresses per mutual agreement of the Parties and appropriate public involvement.

- Work at the OUs will be managed to minimize waste and to prevent the recontamination of OUs previously remediated.

Information contained in this plan comes from detailed technical documents prepared to guide scientific studies, community participation efforts, and cleanup activities. These documents are available for public review at the Information Resource Center, 105 Broadway, Oak Ridge, Tennessee.

\subsection{CERCLA PHILOSOPHY/STRATEGY}

A fundamental goal of cooperative efforts by the Parties in implementing the Agreement is that RA be emphasized. This goal recognizes that no reasonable amount of investigation can resolve all uncertainty and that once RAs are initiated they must be able to accommodate divergence from original hypotheses. This approach promotes earlier remedy selection, flexibility for RA, and contingencies to react to new information discovered during investigations.

The Parties support this goal and will proceed with the ORR ER Program based on the following premises. 
1. OUs consisting of solid waste management unit (SWMU) groupings have been initially identified for the ORR. These OUs will proceed through the formal CERCLA process encompassing investigation field activities, the selection of the appropriate RAs, design and construction, and unit-monitoring activities. During the performance of the remedial investigation (RI) phase, the initial OUs may be further subdivided into additional OUs or combined to best expedite the identification and implementation of the remediation alternatives.

2. Removal actions per CERCLA 101(23) will be used to expedite actions to protect human health and the environment from an imminent threat in the short term. Interim action Records of Decision (RODs) under the National Contingency Plan (NCP) may also be used to institute measures to stabilize the unit and/or prevent further migration or degradation while a final remedial solution is being developed for the OU.

3. Unit characterization will be planned on the basis of optimizing field sampling and maximizing use of available data. In cases where sufficient historical data exist to support or eliminate potential remedies, these data on the OUs will be used to converge early on RAs based on probable unit conditions. Measures will be implemented to effectively manage the uncertainties where the unit has not been fully characterized.

4. Units newly discovered or not yet categorized within one of the existing OUs will be classified as a study area. A preliminary assessment/site inspection (PA/SI) will be performed to properly classify the unit as requiring no further action, requiring immediate action to stabilize the area and provide controlled access, or included in a new or existing OU for processing pursuant to CERCLA/RCRA requirements.

\subsection{PROGRAM INTEGRATION INTO CERCLA}

\subsubsection{RCRA Integration into CERCLA}

The Agreement will establish a procedural framework and schedule for developing and implementing response actions under CERCLA at the ORR. The Parties to the Agreement recognize that current and future hazardous waste management activities may be subject to RCRA permit requirements under federal and state laws. The Parties to the Agreement recognize that on-site CERCLA response actions are not subject to federal or state permits per CERCLA 121(e)(1). However, RCRA shall be considered an applicable or relevant and appropriate requirement per CERCLA 121(d). Hence, current and future response actions at the ORR will achieve comprehensive remediation of releases or threatened releases of hazardous substances, pollutants, and contaminants. RCRA/HSWA administrative requirements and permitting activities will be integrated as necessary into the CERCLA process.

The Parties to the Agreement also recognize that several investigations and actions have proceeded under RCRA requirements. The Parties intend to build upon these efforts (rather than to conduct essentially duplicate, redundant activities under CERCLA) by identifying and documenting functional equivalency of requirements and effecting a transition of such investigations and actions into the CERCLA process.

EPA, DOE, and TDEC are negotiating the Agreement to ensure that the environmental impacts associated with past and present activities at the ORR are thoroughly investigated 
and that appropriate RAs or corrective measures are taken as necessary to protect human health and the environment. This Agreement will establish a procedural framework and schedule for developing, implementing, and monitoring response actions at the ORR in accordance with CERCLA and RCRA. The three parties to the Agreement intend to coordinate the DOE CERCLA response obligations with the corrective measures required under the HWSA permit. Response actions under the Agreement will achieve comprehensive remediation of releases or threatened releases of hazardous substances, hazardous wastes (including hazardous constituents), pollutants, or contaminants at or from the ORR. For this reason, the Agreement supplements corrective actions under the HWSA permit with response actions under CERCLA for releases not presently addressed in the HWSA permit. The parties to the Agreement, therefore, intend that activities covered by the Agreement will be deemed to achieve compliance with CERCLA, to satisfy the corrective action requirements of Sect. 3008(h) of RCRA for interim status facilities, and to meet or exceed all applicable or relevant and appropriate federal and state laws and regulations to the extent required by Sect. 121 of CERCLA.

The Agreement expands the RCRA facility assessments and investigations presently under way at the ORR with requirements to investigate (1) releases at or from units not included in the RCRA permit and (2) releases of hazardous or radioactive substances not regulated by DOE's RCRA Hazardous and Solid Waste Amendment (HSWA) permit. The Parties to the Agreement intend to coordinate the consolidation of these assessments, investigations, and other response actions, as well as the administrative records developed for activities under the RCRA HSWA permit and the public participation requirements of CERCLA. Procedures for the selection of response actions under the Agreement will also be coordinated with the administrative procedures for issuance of any additional RCRA HSWA permits and/or any future permit modifications. The Parties to the Agreement intend to modify the RCRA HSWA permit, as appropriate, to incorporate the RAs selected under the agreement as corrective measures to satisfy Sects. 3004(u) and (v) of RCRA. With respect to releases of hazardous constituents from facilities that are or were authorized to operate under Sect. 3005(e) of RCRA, RCRA shall also be considered an applicable or relevant and appropriate requirement under Sect. 121 of CERCLA. The Parties to the Agreement also recognize that ongoing hazardous waste management activities at the ORR may be subject to or require the issuance of additional permits under federal and state laws. The Agreement does not relieve DOE from its obligations to obtain such permits. The Agreement does not supersede, modify, or otherwise change the requirements of DOE's existing RCRA HSWA permit.

In 1984, 11 interim status RCRA SWMUs on the ORR were identified to be closed rather than pursuing a RCRA part $B$ permit. Under the interim status guidance, eight of these units (shown with an asterisk in the list below) are required to have postclosure permits by November 1992 .

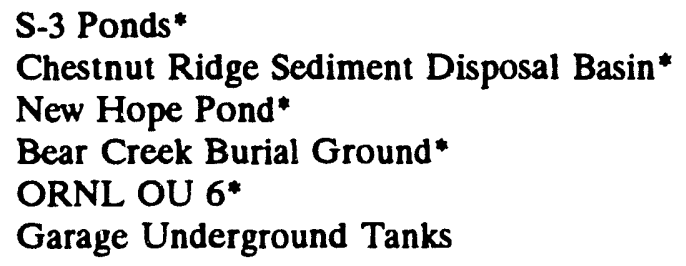

\author{
Oil Landfarm* \\ Chestnut Ridge Security Pits* \\ Kerr Hollow Quarry* \\ 9409-5 Tank Storage Facility \\ Interim Drum Yard
}

The schedule required to meet this RCRA-driven milestone for each of these units will not coincide with the requirements of the CERCLA process, thereby resulting in a duplication 
of effort and redundant activities. The Parties agree that to avoid this waste of time, resources, and effort, the approach detailed below will be implemented as the plan.

The CERCLA response will incorporate RCRA as an applicable and relevant or appropriate requirement (ARAR) for these units. Appendix $A$ provides the generic recommended CERCLA schedule logic for these units, which fulfills all requirements of both CERCLA and RCRA.

\subsubsection{Integration of Other Programs into the CERCLA Process}

DOE Order 5400.4, "Comprehensive Environmental Response, Compensation, and Liability Act Requirements," directs that "where DOE RAs under CERCLA trigger the procedures set forth in NEPA, it is the policy of DOE to integrate the procedural and documentation requirements of CERCLA and NEPA, wherever practical." The primary instrument for this integration will be the RI/FS process, which is to be supplemented as needed to meet the procedural and documentational requirements of NEPA. Documents under the Agreement will, therefore, be prepared in such a way that they will also satisfy NEPA requirements, as appropriate. In addition, the public review processes of CERCLA and NEPA will be combined for RI/FS-NEPA documents, where appropriate.

Other state and federal laws (e.g., those relating to water, air, safety, transportation, etc.) that may constitute ARARs will be addressed in future revisions of this document. 


\section{CERCLA PROCESS}

\section{CERCLA PROCESS OVERVIEW}

Figure 2.1 presents a general overview of the process that will be used to achieve appropriate RA decisions for the various OUs at the ORR. Numbers that appear outside the boxes in Fig. 2.1 refer to figures that provide additional detail for that section. RAs covered under CERCLA 102(23) can occur anytime during the work and will not be addressed separately in this section. An RA is defined as the cleanup or removal of released hazardous substances from the environment. For example, the work being performed at the White Oak Creek Embayment area is typical of RAs taken in the event of a threat of hazardous substances release into the environment.

This site management plan encourages communications among the Parties and provides the necessary flexibility to reach an early determination on an OU and areas undergoing PASI where there is sufficient information. The determination may be that no further action is necessary, that an interim action is appropriate, or that the OU should proceed through the RI/FS process to a final action. This flexibility is supported by distinct paths, decision points, and scoping meetings held with the regulators to ensure consistency of the approach and scope with respect to the complexity of the problems being addressed. The ability of this process to instigate interim actions whenever necessary to protect human health and the environment and stabilize the unit is also portrayed. The process also provides program managers with the flexibility to prioritize work and establish OUs in a manner that will achieve the most benefit with available funds.

Figure 2.2 shows the interrelationship and the generic schedule of the activities to be performed during this process. The regulators may at any time request additional work, including field modifications, remedial investigatory work, or engineering evaluations, which they determine necessary to accomplish the purposes of the Agreement. Should additional work be required and agreed to by DOE, deadlines and schedules for the submission of primary documents (or modifications of primary documents relating to that work) and the target dates for secondary documents, as well as schedules for implementation of any remedial activity, shall be proposed by DOE and reviewed for approval by the regulators. Primary documents are required by the FFA/IAG and must be approved by the Parties. Secondary documents support the information found in primary documents.

The following sections describe the principal parts of the CERCLA process overview flow chart individually. Each section has enough flexibility built into it so that unforeseen circumstances that exist with the remediation of hazardous waste areas can be handled effectively.

\subsection{PRELIMINARY ASSESSMENT/SITE INSPECTION}

The preliminary assessment (PA) is the first phase in the process of determining whether a unit in the study area is releasing, or has the potential to release, hazardous substances, pollutants, or contaminants into the environment and whether it requires response action that is authorized by CERCLA. During the PA, the investigator compiles and evaluates available 
DWG NO. K/G 01-2089 R1

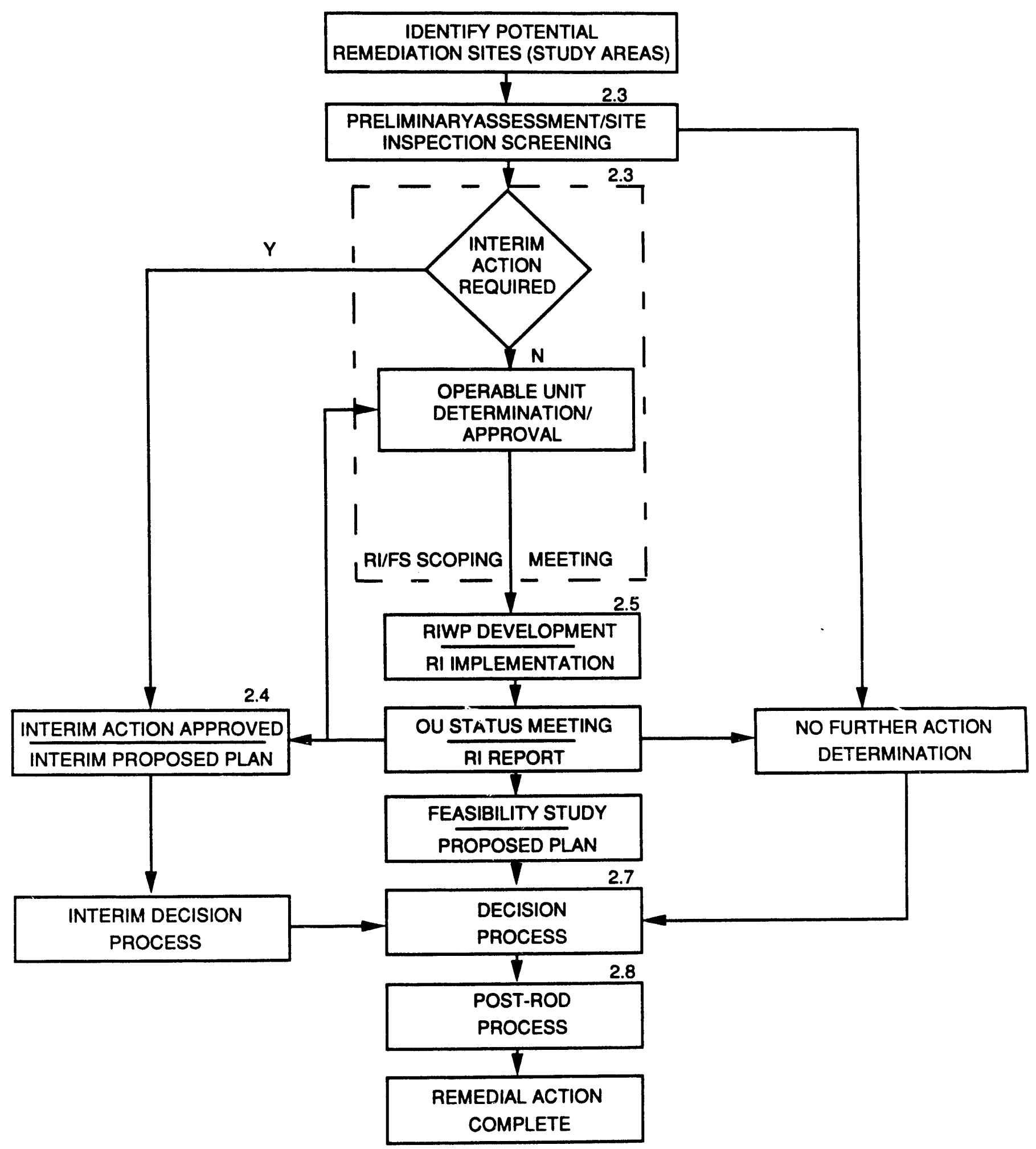

Fig 21. CERCLA process overview. 


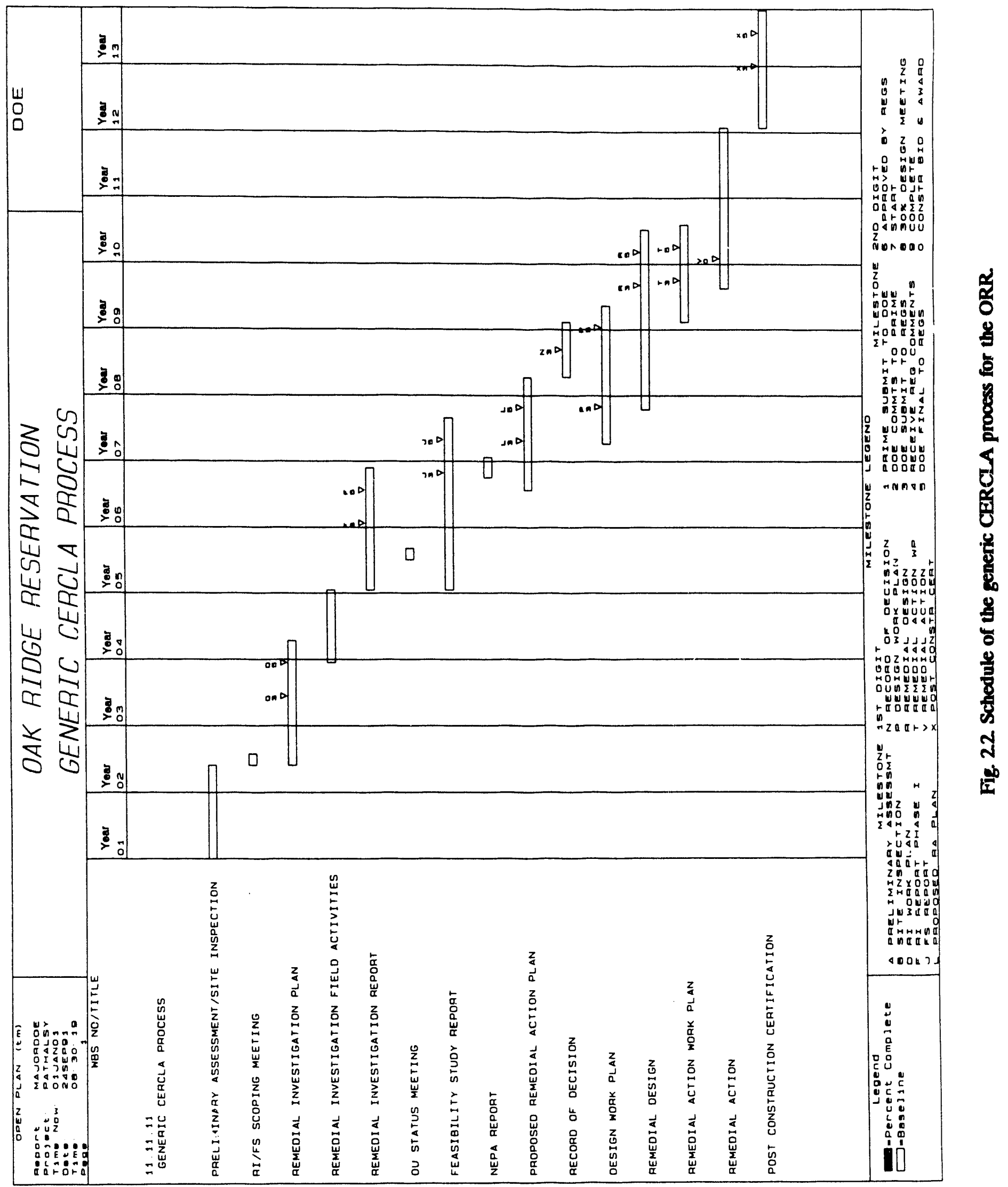


information and data about a unit and its surrounding environment, including information on potential waste sources, migration pathways, and receptors. The PA culminates in a brief report with formal recommendations. This PA incorporates the findings of the site inspection (SI) when there is sufficient cause to warrant the performance of limited sampling and analysis activities. The goal of such sampling is to determine if a release has occurred that requires further characterization and risk assessment through the RI process.

The PASI has three specific goals exemplified by Fig. 2.3:

- Eliminate study area units that are ineligible for CERCLA remedial response, pose no threat to human health or the environment, or where no further action under the remedial program is warranted. The Parties must concur on this determination. This decision is documented through use of the form that appears in Appendix B, and copies of the PAVI information and the form are placed in the Information Resource Center.

- Identify units, or a portion of a unit, that qualify for immediate removal actions or interim remedial actions.

- Identify the appropriate $O U(s)$ to contain the unit(s) for which the RI/FS will be conducted.

A meeting should be held with the Parties to discuss the scope and data needs required to satisfy the regulators prior to starting the SI activities. An RI/FS scoping meeting will be held to determine the direction to be taken at the unit following PA/SI activities.

\section{INTERIM REMEDIAL ACTIONS}

During the PA/SI screening, implementation of the RI activities, or at other points in the RI/FS, the Parties may det ermine that an interim RA is appropriate. Interim RAs are limited in scope and only address specific areas or specific media. The interim RAs will be followed by a final OU ROD. An interim RA should

- take quick action to protect human health and the environment from an imminent threat in the short term while a final remedial solution is being developed or

- institute measures to stabilize the unit or $O U$ and/or prevent further migration or degradation.

The interim RA planning process (Fig. 2.4) may be initiated at any time data provide sufficient justification and when the Parties agree that interim RA is appropriate. A scoping meeting of the Parties initiates the interim RA process. Data are compiled, qualitative risk findings are established, and appropriate technologies are reviewed to develop the proposed interim RA plan. This information initiates the decision process, which results in an Interim ROD for the unit.

The information produced to support the interim RA is incorporated into the ROD for the OU that contains the interim RA area and considered in the development of the final 
DWG NO. KG O1-2000 AI

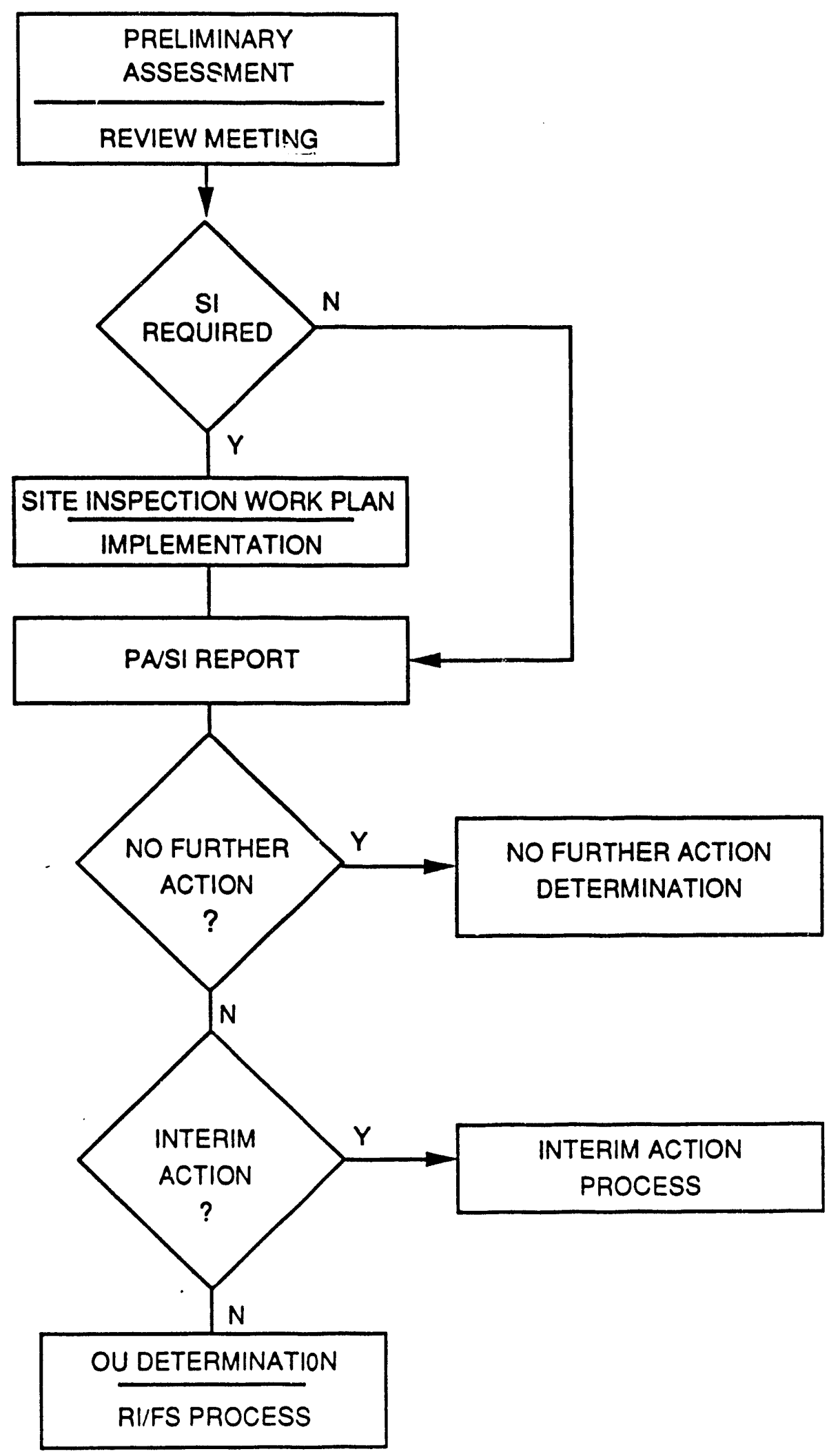

Fig. 23. Preliminary assessment/site inspection process. 


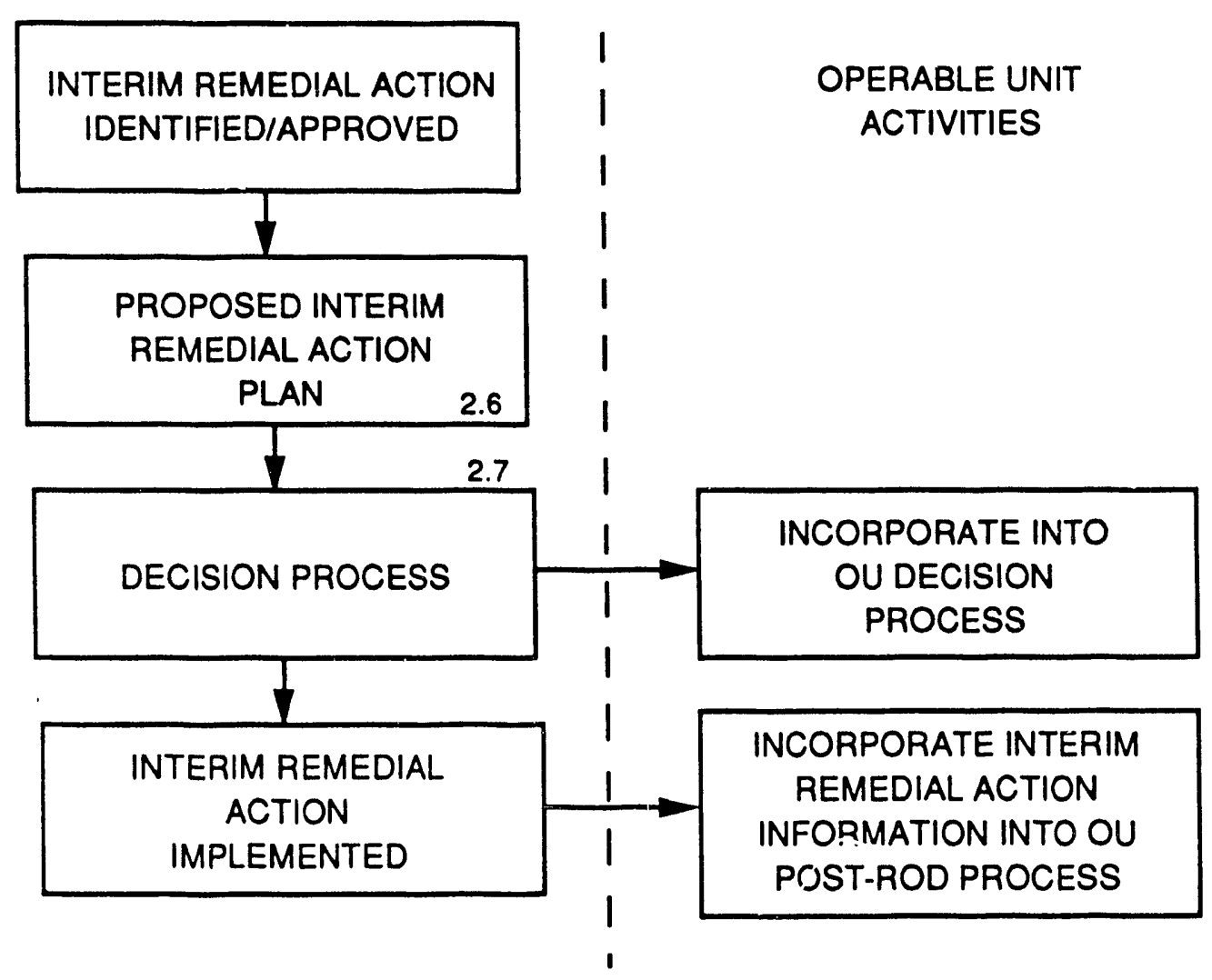

Fig. 24. Flowchart depicting interim remedial actions process. The " 2.6 " shown inside the second box above indicates the review cycle that the document named in the box must go through. The "2.7" shown above the third box indicates that Fig. 2.7 provides additional information. 
remediation for the OU. Postconstruction information from the interim RA will be considered carefully as the OU remedial design plan is developed to minimize the redundancy of effort in the same area. Design of the interim action will be compatible to the extent possible with potential RAs for the OU.

\subsection{RI/FS SCDPING PROCESS}

The RI/FS scoping process is basically the planning process for the OU RI/FS phase described in CERCLA. For each of the defined ORR OUs, there will be a scoping meeting held with the regulators to thoroughly discuss available historical information and the proposed approach to investigating/characterizing the unit. The RI/FS scoping meeting discussions and agreements will provide the basis for the development of the OU RI work plan and will be based on the results of the PA/SI activities. For OUs that contain units where RCRA facility investigation reports have already been developed, the RI work plan produced will build upon and incorporate these work plans. The OU RI work plan will thus become an enhanced addendum to the work performed.

The sampling and analysis plan incorporated in the RI work plan will provide the scope of the characterization work to be performed at the OU. OU field work will be initiated once approval of the RI work plan document has been received from the regulators and DOE. Work on some of the initial OUs has been allowed to start and continue without written approval of these documents. This verbal approval has been given at OU working sessions on a case-by-case basis.

\section{RIFS IMPLEMENTATION}

Figure 2.5 illustrates the generic flow for the RI/FS implementation. Depicted in the figure are all of the primary and secondary documents produced in the RI/FS process (a " 2.6 " inside the flowchart boxes indicates the review process to which the document is subjected). Secondary documents (portrayed in the boxes delineated with dashes) and primary documents, which require approval by the regulators, are made available to the public at the Information Resource Center. Treatability studies should be included in the RI/FS process as needed.

At the ORR, the RI/FS implementation process will accelerate the investigation phase, as much as possible, by relying on the available historical data and limiting field activities. The NCP reflects EPA's promotion of responsiveness and efficiency in the remediation program by encouraging action prior to or concurrent with conduct of an RI/FS as soon as sufficient information is available to support remedy selection (DOE 1990). The unit will be sufficiently characterized and the available remediation technologies evaluated to produce a focused feasibility study to support the most promising option(s) for remediation.

After completion of the field sampling, analytical work, and the baseline risk assessment and prior to the completion of the RI report for the OU, there will be another meeting with the regulators. The purposes of this OU status meeting will be to determine if there needs to be any modification to the OU and if unit characterization has been completed. At this point in the process, it may be determined that some or all of the OU requires (1) no further action, (2) a feasibility study, (3) further characterization and a revised work plan, or (4) an 
Owa ma ko $21-2101$ R1

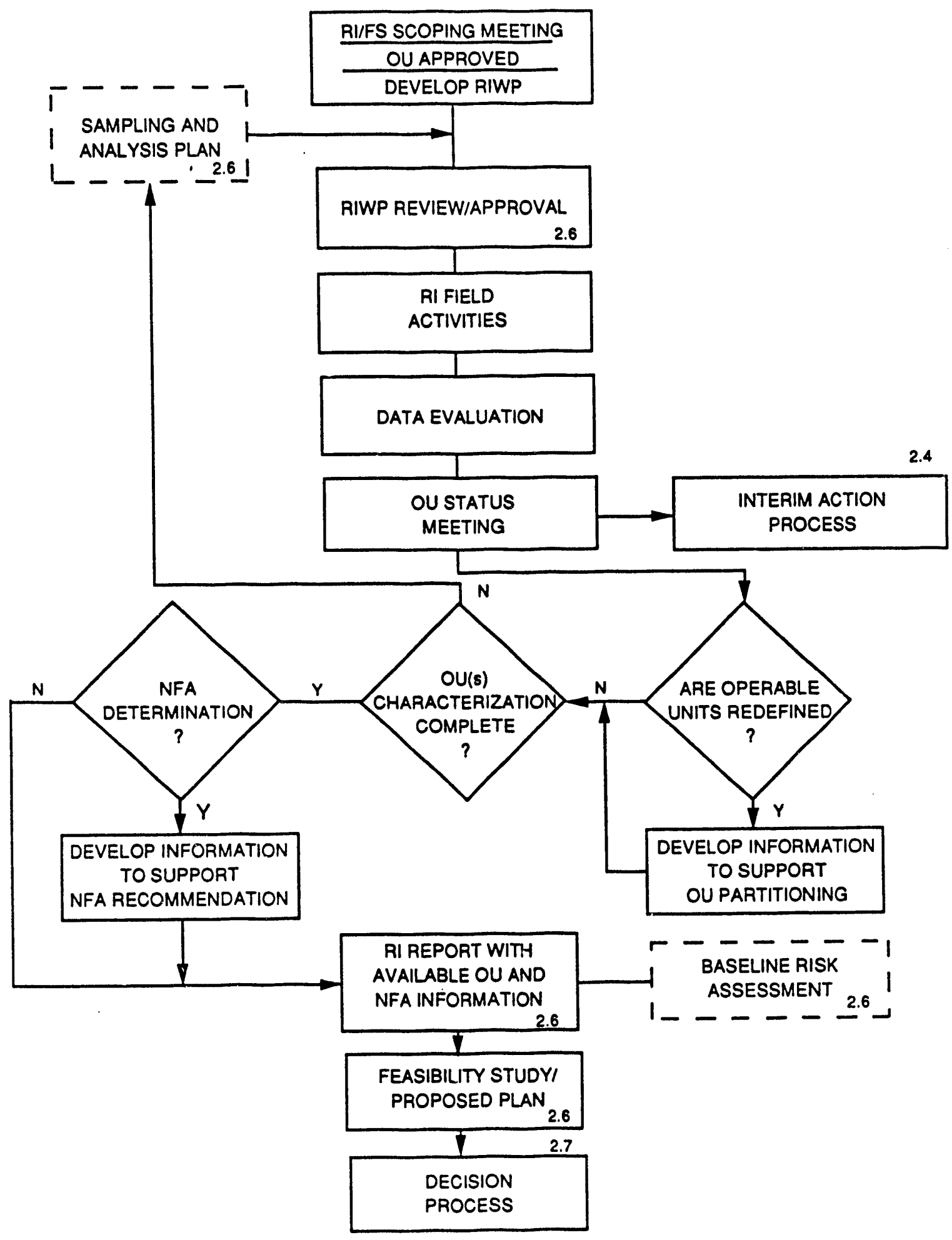

Fig. 25. Generic flowchart showing RIFS implementation process. The "2.6" shown inside several boxes above indicates the review cycle that the document named in the box must go through. Numbers shown above boxes refer to figures that provide additional information. 
interim action. This determination has the potential for creating additional OUs from the initial OU and/or adding units from other OUs or the OU study areas defined at the scoping meeting.

The two meetings held during the RI/FS scoping and implementation phases allow the Parties to stay informed of the work being performed, thus streamlining the process and building in the necessary flexibility required to match the CERCLA process to the problems encountered at the OU.

\section{REVIEW/DECISION PROCESS}

Each primary document generated in the course of the investigation and cleanup will be reviewed and approved by the regulators. The secondary documents, usually developed in the course of the work and incorporated into the primary documents, are sent to the regulators for review but not for approval. The Agreement has specified this review cycle in detail (FFA, Sect. XXI) (Fig. 2.6). If the Parties cannot reach agreement on the technical information presented in the primary documents, the disagreement can be resolved in the resolution of dispute process documented in Sect. XXVI of the Agreement. Each of the generated documents are made available for the public at the Information Resource Center at the time they are transmitted to the regulators for review.

The decision process, as described in Fig. 2.7, is initiated when there is adequate information to select an interim or final remedy for an OU. The decision process is initiated with the submittal by DOE of the proposed RA plan for regulatory review. Once the proposed plan has been approved by the regulators, the formal public review period is announced in the local newspapers. All public review and comment periods and other mechanics of the decision process follow guidance from NCP, EPA, and the ORR Community Relations Plan (PEER 1991). The alternative(s) selected for the remediation of the OU and the responsiveness summary, the significant comments generated by members of the public, and the responses to those concerns are documented in the ROD, which is also submitted to the regulators for review as a primary document. When the ROD is signed, the decision is complete, and DOE will issue the final ROD with EPA/TDEC concurrence. The "resolution of dispute" process can also be used if there is disagreement on the alternative to be selected for the OU.

\section{ROD SCHEDULE}

Appendix C provides the ROD schedule for all identified ORR OUs. Most schedules currently reflect generic time frames for the activities to be performed. These schedules will be refined through the prioritization and budgeting process and through meetings held with the regulators. Only the approved ROD schedules for the current fiscal year are enforceable deadlines; Appendix $\mathrm{E}$ of the Agreement provides the enforceable primary and secondary document milestones for the current fiscal year. This information is available at the Information Resource Center. 


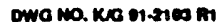

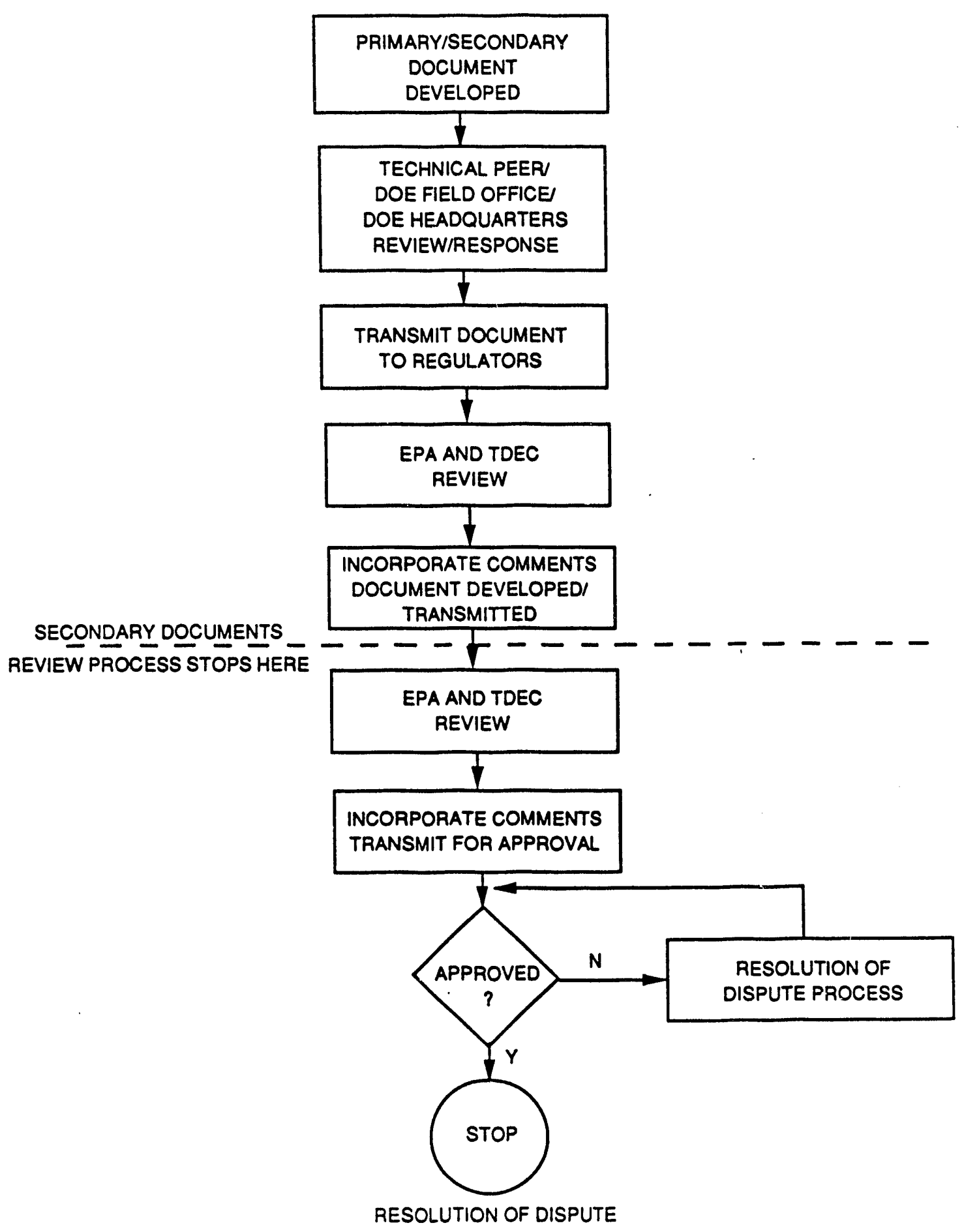

Fig. 2.6. Document review process specified by the Agreement. 


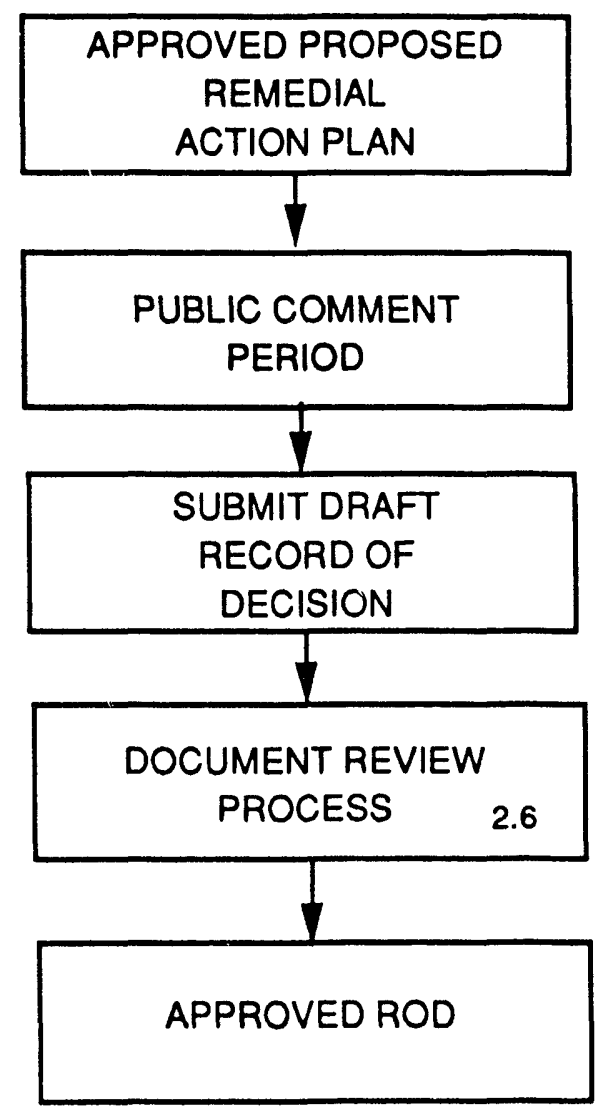

Fig. 27. The decision process for FFA/AG documents. 


\section{POST-ROD PROCESS}

The purpose of this section is to describe the general process and documentation necessary to implement the ROD at the ORR (Fig. 2.8). Post-ROD activities include the design and construction phases required when the ROD requires further action at the OU. The design work will be streamlined to the extent possible to meet the CERCLA requirement to commence substantial continuous physical RA within 15 months of issuance of an approved ROD. The regulators will be closely involved in the design work to ensure timely approval of the RA work plan.

Following final selection of the RAs, the proposed RA implementation plan for the selected RAs, including appropriate timetables and deadlines, will be submitted to the regulators for review.

\section{REMEDIAL DESIGN PROCESS}

When the ROD stipulates RA, the remedial design (RD) phase will be initiated with the development of the RD work plan (Fig. 2.8). Given the critical nature of the RD, it will be necessary to provide regulatory agencies with early design documents to ensure that consensus is maintained. This will be accomplished through working sessions with the regulators and submittal of preliminary design documents, usually at $30 \%$ completion, for their review. When the plans and specifications reach $90 \%$ completion, this document will be submitted as the primary RD document. At this time, all aspects of the design will be essentially complete; the final $10 \%$ of the design will include the resolution to the comments from the regulators on the RD document. This will, in effect, accelerate the design review and approval process. The RA work plan will be submitted with the $90 \%$ RD document.

\subsection{REMEDIAL ACTION PROCESS}

Once approval has been obtained on the RA work plan, substantial and continuous RA construction activities will begin. A concerted effort will be made by all Parties to ensure that this happens within 15 months of issuance of an approved ROD as directed by CERCLA. The primary RA postconstruction report will be prepared at the completion of the RA phase and will include the following:

- A brief description of outstanding items from the prefinal inspection conducted by the project managers and their resolution

- A synopsis of work defined in the RA work plan and certification that this work was performed

- Explanation of any modifications to the RA work plan

- Certification that the remedy is operational and functional

- Documentation necessary to support deletion of the unit from the NPL, as discussed in Sect. XIVI of the Agreement 
DWG NO. KUG 91-2105

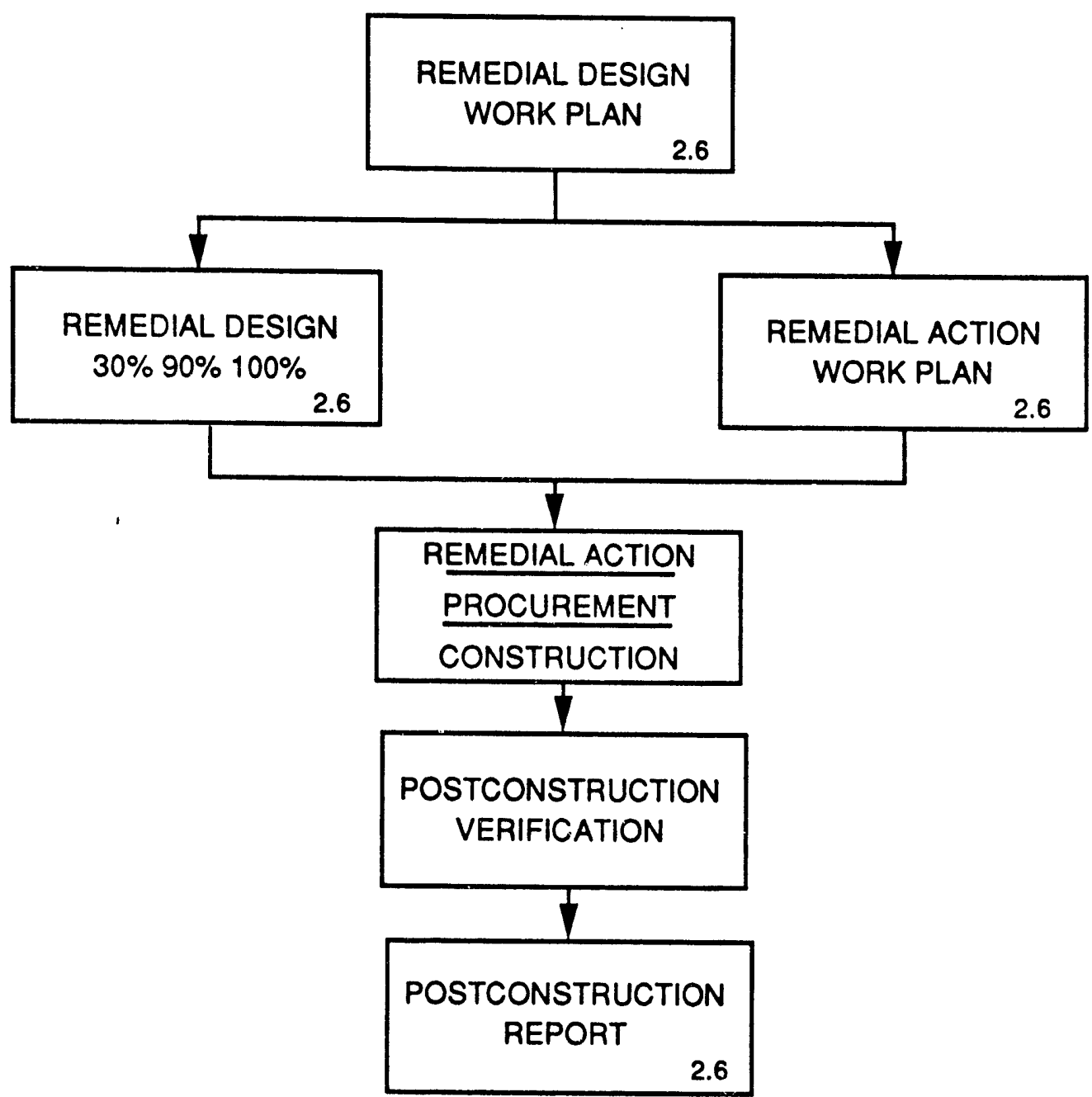

Fig. 28. The post-ROD process. 


\subsection{POSTREMEDIATION MONITORING}

At the completion of the construction phase, a proposal for the monitoring plan and schedule will be submitted if the remediation selected for the OU warrants this continued oversight.

CERCLA requires periodic reviews-at least every 5 years-at units where RA leaves hazardous substances, pollutants, or contaminants. This means that whenever a remedy is selected that assumes limited uses of the land or relies on institutional controls to ensure attainment of protective exposure levels, a review will be conducted. In addition to the 5-year reviews required by statute, the ROD may specify more frequent reviews or specific reviews of the remedy selected, such as assessments of remedial technologies that might not have been available at the time the decision was made. 


\section{OU/STUDY AREA CONCEPT AND OU DESCRIPTION}

The ORR consists of about 58,000 acres of federally owned land in Oak Ridge. The ORR is bounded on the north and east by the city of Oak Ridge (population 28,000) and on the south and west by the Clinch River. The area surrounding the ORR is predominately rural, used largely for residences, small farms, and pasture land. Fishing, boating, water skiing, and swimming are favorite recreational activities in the area.

The ORR consists of three major operating facilities: ORNL, the Oak Ridge K-25 Site (formerly the Oak Ridge Gaseous Diffusion Plant), and the Oak Ridge Y-12 Plant (see Appendix D, Fig. D.1). The ORR generates a variety of hazardous substances, including radioactive, nonradioactive, and mixed wastes, some of which have been released into the environment at the ORR. Under its RCRA permit, DOE has begun the RI process at over 500 SWMUs at the ORR.

An OU is defined as a WAG for which an RI/FS will be performed. On the ORR, many of the SWMUs have been grouped according not only to their proximity but also by common physical and hydrogeological parameters. The units included not only the SWMUs identified under the guidance of RCRA but also groundwater and surface water on and near the ORR. This grouping, the current OU listing, was baselined by the Parties in the spring of 1991 and included in Appendix E.

The existing information on the other SWMUs is insufficient to logically group these units into OUs. These units (study areas) will be further accessed under the PA/SI phase and designated for potential inclusion into new or existing OUs. Working meetings will be held regularly with the Parties to determine the status of the OUs and study areas.

The following sections describe the breakout of waste areas into OUs for the ORR.

\subsection{OAK RIDGE NATIONAL LABORATORY WAGs/OUs}

ORNL occupies several areas and covers $\sim 2900$ acres in Melton Valley and Bethel Valley, 10 miles southwest of downtown Oak Ridge, Tennessee. ORNL's mission is to conduct applied research and engineering development in support of DOE programs in fusion, fission, conservation, fossil, and other energy technologies and to perform basic scientific research in selected areas of the physical and life sciences. The laboratory was built in 1943 as part of the World War II Manhattan Project. Its original mission was to produce and chemically separate the first gram quantities of plutonium as part of the national effort to produce the atomic bomb. ORNL's groupings of SWMUs are so numerous at this time that the breaking of these groups into additional OUs is certain. Therefore, ORNL has retained the term "WAG" to facilitate the imminent reorganization into OUs. The terms "WAG" and "OU" are virtually equivalent at this time. A map showing ORNL WAGs/OUs can be found in Appendix D, Fig. D.2.

\subsubsection{ORNL WAG 1}

ORNL WAG 1 consists of 117 individual SWMUs requiring, or potentially requiring, remediation. The unit consist of low-level liquid waste collection and storage tanks; leak and 
spill areas and contaminated soils; ponds and impoundments; waste treatment facilities; shallow land burial and other solid waste storage areas; and other miscellaneous chemical and sewage waste facilities. These units are located in the main plant area. A variety of contaminants of concern are present within this OU.

\subsubsection{ORNL WAG 2}

ORNL WAG 2 contains two units. The first unit consists of the area encompassed by the stream channels of White Oak Creek (WOC) and Melton Branch; the second unit includes White Oak Lake (WOL), White Oak Dam, and the Embayment prior to confluence with the Clinch River. WOC/WOL and the tributaries represent the major drainage system for ORNL and the surrounding facilities.

WOC and its tributaries are located in Melton and Bethel valleys. The creek and its tributaries have been contaminated by waste disposal practices since ORNL was opened. WOC flows into the Clinch River about 1.5 miles $(2.4 \mathrm{~km})$ north of the junction of Interstate 40 and Highway 95. Main contaminants are ${ }^{90} \mathrm{Sr},{ }^{60} \mathrm{Co},{ }^{137} \mathrm{Cs},{ }^{3} \mathrm{H}$, and metals (mercury, zinc, and chromium). Hazardous chemicals, including polychlorinated biphenyls (PCBs), may also be present in the stream sediments.

WOL and its embayment area is located upstream and downstream of White Oak Dam, south of the ORNL main complex, and near Clinch River Mile 20.8 (CRK 33.5). The dam was built about 0.6 mile $(1.0 \mathrm{~km})$ upstream from where WOC empties into the Clinch River. The area is a surface impoundment for radioactive and other hazardous wastes that drain from ORNL via the WOC watershed. It serves as a final settling basin for waste released from ORNL operations and waste storage areas. Contaminants of concern identified to date are ${ }^{90} \mathrm{Sr},{ }^{137} \mathrm{Cs}$, thorium, uranium, transuranics (TRU), and metals (mercury, zinc, and chromium). Hazardous chemicals, including $\mathrm{PCBs,} \mathrm{may} \mathrm{also} \mathrm{be} \mathrm{present} \mathrm{in} \mathrm{the} \mathrm{stream}$ sediments.

\subsubsection{ORNL WAG 3}

ORNL WAG 3 is composed of three units: Solid Waste Storage Area (SWSA) 3, the Closed Scrap Metal Area, and the Contractors' Landfill. SWSA 3 is located in Bethel Valley in a fenced area at the foot of Haw Ridge about 0.6 mile $(1.0 \mathrm{~km})$ west of the ORNL complex. The 7-acre area was commissioned in 1946 and used as a landfill for the storage of low-level solid radioactive waste and scrap metal. It was taken out of service in 1951. Contaminants of concern identified to date include small amounts of TRU, ${ }^{90} \mathrm{Sr}$, and ${ }^{3} \mathrm{H}$.

The Scrap Metal Area is a 4-acre triangular shaped section located in the south portion of the fenced area of SWSA 3. It was used to store contaminated metal between 1951 and 1976. Most of the scrap has now been buried in other SWSAs; however, some contaminated tanks and equipment are still stored above ground. The primary contaminant of concern identified to date is ${ }^{137} \mathrm{Cs}$.

The Contractors' Landfill is located west of SWSA 3. The purpose of this landfill was disposal of debris from construction areas and noncontaminated demolition activities. This 7-acre area is also used as a disposal area for fly ash from the ORNL steam plant. No contaminants of concern are believed to be present at the Contractors' Landfill, but there is no documentation in support of this assumptirn. 


\subsubsection{ORNL WAG 4}

ORNL WAG 4 is composed of three units: a shallow-land burial ground containing radioactive and hazardous wastes (SWSA 4); two pilot-scale, liquid low-level waste (LLLW) seepage pits; and an inactive LLLW line north of Lagoon Road.

SWSA 4 is located in Melton Valley about 0.5 mile $(805 \mathrm{~m})$ southwest of the main ORNL complex. The unit is bounded on the northern side by Lagoon Road. SWSA 4 covers an area of 23 acres and was used from 1951 to 1959 for the storage of radioactive solid waste. For a period of time, the landfill was designated as the Southern Regional Burial Ground by the Atomic Energy Commission and received wastes from nuclear installations in the eastern United States. Contaminants of concern identified to date include ${ }^{3} \mathrm{H},{ }^{90} \mathrm{Sr},{ }^{60} \mathrm{C}$ ), ${ }^{125} \mathrm{Sb}$, and ${ }^{137} \mathrm{Cs}$.

The two pilot pits are located south of SWSA 4 on the road leading to the waste pits and trenches. The unit was originally constructed to perform pilot-scale experiments related to fixation of high-level radioactive wastes (1955-1959) but is now used for storage of equipment and leaching tests on coal and municipal solid wastes. Radionuclides are the only contaminants stored here, and no releases have been reported.

The LLLW line, located on the north side of Lagoon Road, was used to transfer LLLW to the pits and trenches in WAG 7. The first 1.5 -mile $(2.4 \mathrm{~km})$ section of the waste transfer line was installed in June 1954 to transfer LLLW from the Bethel Valley waste storage tanks to Waste Pit 2. Carbon steel extensions to Trench 5 (1960), Trench 6 (1961), and finally to Trench 7 (1962) completed the transfer line to the waste pit area. In 1966, a cast-iron line was installed from Trench 7 to the Old Hydrofracture Facility (1.5 miles). Wastes handled in the transfer system were routinely generated laboratory LLLW.

\subsubsection{ORNL WAG 5}

ORNL WAG 5 is composed of 16 units including LLLW transfer lines and leak locations; hydrofracture surface facilities; waste storage tanks; a sludge basin and a holding pond; a shallow land burial ground containing radioactive and hazardous wastes (SWSA 5); and a TRU waste storage area.

These units are located east of WOC, between SWSA 4 and Melton Branch. SWSA 5 is a fenced area of about $\mathbf{8 0}$ acres and was used for disposing of routine buried waste (south side) and TRU contaminated waste (north side). The major contaminants detected in water seepage are ${ }^{90} \mathrm{Sr}$ and ${ }^{3} \mathrm{H}$.

\subsubsection{ORNL WAG 6}

ORNL WAG 6 consists of SWSA 6, the Emergency Waste Basin, and the Explosives Detonation Trench. SWSA 6 is located northwest of WOC near White Oak Dam and State Highway 95. This 68-acre unit is still in operation as a waste burial ground containing solid low-level radioactive waste. Contaminants of concern include various radionuclides and hazardous chemicals.

The Emergency Waste Basin is located north of SWSA 6. It is a 2-acre basin constructed as an LLLW or process-waste holding basin for use when ORNL might be unable to release 
wastes to WOC. The basin has never been used, and no releases have been detected in the stream leaving the basin; however, surface contamination has been found in the basin.

The Explosives Detonation Trench is located in the northern part of SWSA 6. It was used to detonate explosives and shock-sensitive chemicals requiring disposal. Waste was laid in the bottom of the trench and detonated with a small plastic explosive charge. No releases are believed to have occurred.

\subsubsection{ORNL WAG 7}

ORNL WAG 7 comprises 17 units: 7 LLLW seepage pits and trenches, Homogeneous Reactor Experiment (HRE) fuel wells, experimental hydrofracture injection areas and surface contamination, shielded transfer tanks, and a decontamination facility.

These units are located in the vicinity of SWSA 4 (in Melton Valley about 0.5 mile southwest of the main ORNL complex and bounded on the northern side by Lagoon Road). Several radioactive contaminants of concern have been identified to date.

\subsubsection{ORNL WAG 8}

ORNL WAG 8 is made up of 27 units which include waste collection basins, LLLW lines and leak locations, and an experimental hydrofracture injection area with associated soil contamination, LLLW collection/storage tanks, a hazardous waste storage facility, a mixed waste storage pad, a sewage treatment plant, and a silver recovery plant.

These units are located in the area of the 7000 buildings in the vicinity of the High Flux Isotope Reactor, the Melton Valley Pumping Station, the Thorium-Uranium Recycle Facility, the Molten Salt Reactor Experiment Building, and the Transuranium Processing Plant. Various radioactive contaminants have been used at these units, but very few releases have been reported or identified as being above background levels.

\subsubsection{ORNL WAG 9}

ORNL WAG 9 is made up of six units: the HRE Pond, two inactive LLLW collection and storage tanks, a trash area, the Waste Evaporator, and the Waste Evaporator Loading Pit.

The HRE Pond is located in Melton Valley, 0.5 mile $(800 \mathrm{~m})$ southeast of the ORNL complex. It is situated south of Building 7500, above Melton Branch. The pond received contaminated condensate from the reactor evaporator from 1958 to 1961 . Contamination is mainly from ${ }^{137} \mathrm{Cs}$ and ${ }^{90} \mathrm{Sr}$, with trace amounts of ${ }^{238} \mathrm{Pu},{ }^{239} \mathrm{Pu},{ }^{241} \mathrm{Am}$, and ${ }^{244} \mathrm{Cm}$.

The LLLW collection and storage tanks (7560 and 7562) are located south of the Waste Evaporator and north of the Waste Holding Pond, respectively. The 7560 tank (1957-1961) held condensed clean vapor from the evaporator cell until the liquid could be sampled. The 7562 tank was designed to hold high-level waste from 1957 to 1986. Major radionuclides of concern in LLLW are considered to be ${ }^{90} \mathrm{Sr},{ }^{137} \mathrm{Cs},{ }^{60} \mathrm{Co}$, and TRU for both tanks.

The trash area east of the HRE parking lot, is north of Melton Valley Drive and across from Building 7500. The unit formerly contained an old farm house that was used by HRE-1 
and HRE-2 for storage. During the early-to-middle 1960s, all stored material, some contaminated with radioactivity, was removed for disposal. Construction debris, perhaps containing some waste contaminated with radionuclides, is visible at the east end of the area.

The Waste Evaporator is located in Building 7502 on Melton Valley Road, 0.6 mile $(1.0 \mathrm{~km})$ southeast of the main ORNL complex. The unit contains the reactor (Building 7500), the waste evaporator (Building 7502), a hot storage and decontamination pad, and a filled-in waste holding pond. The facility was intended for three phases of experimentation during the 1950s. Due to accelerated corrosion during the first experiment, the second and third experiments were never begun. A small probability exists for significant exposure from highly radioactive insoluble corrosion and fission products that remain in the process piping.

The Waste Evaporator Loading Pit is located outside and adjacent to the east wall of the Waste Evaporator. The pit was used to load carriers with LLLW from the Waste Evaporator during the 1950 s. The pit is contaminated, and major radionuclides are ${ }^{90} \mathrm{Sr},{ }^{137} \mathrm{Cs}$, and ${ }^{60} \mathrm{Co}$.

\subsubsection{ORNL WAG 10}

ORNL WAG 10 consists of the injection wells and grout sheets associated with two hydrofracture process experimental locations, the Old Hydrofracture Facility (OHF), and the New Hydrofracture Facility. The facilities themselves are associated with WAGs 5, 7, and 8.

The Hydrofracture Experiment Site 1 is located within the boundary of WAG 7 (south of Lagoon Road) and was the first experimental injection of grout (October 1959) as a testing program for observing the fracture pattern created in the shale and to identify potential operating problems. Waste injected was water-tagged with ${ }^{137} \mathrm{Cs}$ and ${ }^{141} \mathrm{Ce}$. Grout consisted of diatomaceous earth and cement. No hazardous waste constituents or LLLW should have been present in the grout.

The Hydrofracture Experiment Site 2 is located about 0.5 mile $(800 \mathrm{~m})$ south of the 7500 (experimental reactor) area (WAG 8). The second hydrofracture experiment was designed to duplicate, in scale, an actual disposal operation. However, radioactive tracers were used instead of actual waste. Water tagged with ${ }^{137} \mathrm{Cs}$, cement, and bentonite were used in formulating the grout. No nonradioactive hazardous constituents should be contained in the grout.

The OHF is located 1.0 mile $(1.8 \mathrm{~km})$ southwest of the main ORNL complex, west of SWSA 5. The facility, commissioned in 1963, served as a pilot plant to demonstrate the feasibility of permanent disposal of liquid radioactive waste in impermeable shale formations by hydrofracture methods. Wastes used in the experiments included concentrated LLLW, ${ }^{90} \mathrm{Sr}$, ${ }^{137} \mathrm{Cs}$, ${ }^{244} \mathrm{Cm}$, TRU, and other unidentified radionuclides.

The New Hydrofracture Facility is located $900 \mathrm{ft}(300 \mathrm{~m})$ southwest of the OHF on the south side of Melton Branch. The facility was constructed to replace the OHF and serve as the operational LLLW waste disposal system for ORNL. Wastes used in the injections were concentrated LLLW and sludge removed from the gunite tanks, ${ }^{90} \mathrm{Sr},{ }^{137} \mathrm{Cs},{ }^{244} \mathrm{Cm}$, TRU, and othir nuclides. 


\subsubsection{ORNL WAG 11}

ORNL WAG 11 is the White Wing Scrap Yard located at the west end of East Fork Ridge between State Highway 95 (White Wing Road) and the Oak Ridge Turnpike. The unit, which covers about 20 acres, was used to store contaminated materials from the three Oak Ridge plants. Wastes (equipment, tanks, and trucks) were stored above ground. Much of the stored materials and contaminated soil was removed in 1966-1971; however, some scrap metal, concrete, and other waste remains. Contaminants of concern identified to date are gamma radiation, ${ }^{137} \mathrm{Cs},{ }^{234} \mathrm{Th},{ }^{235} \mathrm{U}$, and $\mathrm{PCBs}$.

\subsubsection{ORNL WAG 13}

ORNL WAG 13 consists of the Cesium-137 Contaminated Field and the Cesium-137 Erosion/Runoff Study Area. The contaminated field is located about $330 \mathrm{ft}(100 \mathrm{~m})$ north of the Clinch River at Clinch River Mile 20.5. The 50-acre area was set aside to study simulated fallout of ${ }^{137} \mathrm{Cs}$, which would occur in the event of a nuclear war. The contaminant consisted of ${ }^{137} \mathrm{Cs}$ fused at high temperature to silica particles. After $\sim 20$ years (since contamination), about $5.2 \mathrm{Ci}$ of activity should remain.

The Erosion/Runoff Study Area is located due north of the confluence of the WOC and the Clinch River. The purpose of this study area was to use the field contamination to study runoff, erosion, and infiltration of ${ }^{137} \mathrm{Cs}$ on a silt-loam soil. The unit was contaminated on October 20,1964, and is still under study.

\subsection{ORAU AND CSX RAILROAD OUs}

\subsubsection{Freels Bend Area OU}

The Freels Bend Area (FBA) was used to support research conducted at the ORAU South Campus Facilities (SCF). This area is located southwest of the SCF and is bounded on three sides by the Clinch River (see Appendix D, Fig. D.3). Control herds of some animals were maintained on pasture land here with ancillary barns and outbuildings. The research facilities included the Low Dose Rate Irradiation Facility (LDRIF) and the Variable Dose Rate Irradiation Facility (VDRIF). Each of these facilities was used to expose and irradiate test animals that were subsequently observed over a period of time for exposure effects. The sources were removed from the LDRIF; however, six sealed ${ }^{60} \mathrm{Co}$ sources still remain stored at the VDRIF.

There are three reported disposal areas for animal carcasses and miscellaneous wastes in the FBA. These areas have been termed Animal Burial Sites I, II, and III. Access to the 70 acres of the FBA is restricted and not open to the general public, although the area is not fenced.

FBA areas to be investigated include those associated with the irradiation facility and animal burial locations. Contaminants of concern include radionuclides, target compound list (TCL) organics, and target analyte list (TAL) metals. 


\subsection{South Campus Facility OU}

The SCF OU is located within the city limits of Oak Ridge, Tennessee. It is bounded by Bethel Valley Road to the north, State Highway 62 to the east, Haw Ridge and the Clinch River to the south, and the western section of Bethel Valley to the west (see Appendix D, Fig. D.3).

The SCF is a research facility operated by ORAU. The facility was originally established in 1945 to study the accidental irradiation of cattle which occurred during the testing of the first atomic bomb near Alamogordo, New Mexico. The scope of research soon included studies on radioisotope introduction and transport in the food chain, along with various other agricultural problems.

The boundaries of SCF encompass $\sim 25$ buildings and 130 acres of pasture land, but there is no enclosing fence. Access to the SCL property is generally unrestricted. No fences or barriers exist to preclude access, although several signs are posted.

There is no documented evidence available as to waste composition or quantity that may have been released to the environment at this location. Limited data do exist, however, which identify potential hazardous waste sources and pathways. In addition, previous analytical data indicate the presence of TCL organics in the groundwater and Wastewater Treatment Facility sludge from the unit.

SCF areas to be investigated include the wastewater treatment plant, ponds, various laboratories, and animal containment facilities. Contaminants of concern include radionuclides, TCL, and TAL metals.

\subsection{CSX Railroad OU}

The CSX Railroad is located within the city of Oak Ridge, Tennessee. It is bounded by the Oak Ridge Turnpike (State Highway 95) to the north, Melton Hill Lake to the east, Pine Ridge to the south, and a portion of Illinois Avenue (State Highway 62) and the Y-12 Plant to the west (see Appendix D, Fig. D.4).

Previous surveys along the CSX railroad tracks indicate elevated levels of ${ }^{137} \mathrm{Ce}$ in two areas along the siding. One of these sections is at the northeastern portion of the CSX railroad tracks and is referred as the Warehouse Road section. The other section is located at the southwestern portion of the railroad tracks, by Scarboro Road and Y-12, and is referred to as the Y-12 or Scarboro Road section. The contamination most likely occurred during the early 1960 s when Oak Ridge served as the eastern regional burial ground for low-level radioactive waste generated by civilian and defense activities and such waste was routinely shipped to Oak Ridge by train. The particular source of the contamination has been tentatively identified as leaking concrete casks containing mostly ${ }^{137} \mathrm{Cs}$-bearing animal carcasses.

The boundaries of the CSX study area include the total length of the tracks and the width of the railroad track right-of-way. Public accessibility to the area is unrestricted. The $\mathrm{RI}$ for this unit will focus on the extent of ${ }^{137} \mathrm{Cs}$ contamination and the resultant risk to human health and the environment. 


\section{$3.3 \mathrm{~K}-25$ OUs}

The Oak Ridge K-25 Site was built as part of the Manhattan Project during World War II to supply uranium-enriched material for nuclear weapons production. Construction of the K-25 Site started in 1943, and Building K-25, the first diffusion facility for large-scale separation of ${ }^{235} \mathrm{U}$, was fully operable by August 1945. Additional buildings involved in the enrichment process were operable by 1956 . In response to the national postwar nuclear emphasis, plant operations were modified to include the production of uranium compatible with reactors used to generate electric power. Because of the declining demand for enriched uranium, the enrichment process was placed on standby in 1985 and shut down in 1987. The K-25 Site now has a multipurpose mission that includes being the location of many contractor central staff functions, operating waste treatment facilities, serving as a center for applied technology, and supporting the development of the Advanced Vapor Laser Isotope Separation uranium enrichment technology.

Sixteen OUs have been identified at the K-25 installation, and ten additional units have been designated as PA/SI and future consideration study areas (see Appendix D, Fig. D.5). The study areas will require additional examination to determine whether an RI/FS is necessary. The location, operational history, and potential contaminants of concern for each OU are given in the following sections.

\subsubsection{Area 1 Groundwater OU}

The Area 1 Groundwater OU covers a 300 -acre area roughly bounded by plant grid lines $\mathrm{S} 230+00 / \mathrm{S} 260+00$ and $400 \mathrm{~W} / 5200 \mathrm{E}$. The OU is the potential receptor of 38 possible source units. An RI is planned for 21 of those sources. Contaminants are primarily organic but also contain radioactivity and metals.

\section{$3.32 \mathrm{~K}-1401$ OU}

The K-1401 OU is located at Building K-1401 between 10th and 14th streets, west of Avenue D. Practical components are an acid line and degreasing operation.

Since the 1940 s, the K-1401 Acid Line has received wastes from a variety of nearby operations. Cleaning operations have included the use of degreasers, caustics, and acids. Degreasers were carbon tetrachloride, trichloroethylene, and trichloroethane. Process equipment exposed to $\mathrm{UF}_{6}$ and cleaned in $\mathrm{K}-1401$ would release uranium-contaminated cleaning solutions to the acid line. Instruments and containers from the K-1420 Mercury Recovery Room were processed through the K-1401 cleaning area, resulting in the possibility of small amounts of mercury being discharged to the acid line. Cleaners used were caustics, detergents, trioxide, and soap-oakite. Acids included hydrochloric, sulfuric, chromic, and sulfamic. Organics were methyl ethyl ketone, aromatic hydrocarbons, acetone, and Freons. The acid line was also used to dispose of paints, epoxies and cutting oils.

The K-1401 Degreasers, in operation since the 1940s, have used 1,1,1-trichloroethane as a vapor degreaser to clean process equipment. 


\subsubsection{K-1407 OU}

The K-1407 OU contains a neutralization pit, holding pond, retention basin, natural stream, two hazardous waste storage tanks, a burial ground, and soil excavated from a building project. The OU is roughly bounded by Blair Road, Poplar Creek Road, 15th Street, and Avenue C.

K-1407-A Neutralization Pit consists of a 33,000-gal reaction pit where sulfuric acid and calcium hydroxide are added to neutralize corrosive waste streams. The neutralization pit processed various cleaning solutions and received heavy metals. Contents of the pit were discharged to the K-1407-B Holding Pond, a 1.3-acre impoundment with a capacity of 2.5 million gal. The holding pond also received wastes, including uranium, mercury, TRUs, Miller's Fluorinated Lubricating (MFL) oil, organic cleaners, Freon, and PCB oils from nearby operations. In 1973, sludge was removed from the K-1407-B pond to the K-1407-C Retention Basin, a surface impoundment with a capacity of about 2.5 million gal.

K-1070-B Classified Burial Ground, located north of the K-1401 Building and west of the K-1407-B Pond, was operated from the early 1950 s to 1976 . Materials buried there include uranium-contaminated scrap metal, uranium, uranium fluorides, oxy-fluorides, tetrafluorides, lead and monel. Organics or oils disposed of at the unit are thought to be minimal.

$\mathrm{K}-1407$ soil upgradient of $\mathrm{K}-1407-\mathrm{C}$ is contaminated with uranium and covers $\sim 2$ acres. The K-1202 Hazardous Waste Storage Tanks are two tanks used since 1944 to store lubricating oil. Since 1989, the north tank has contained mixed wastes.

$\mathrm{K}-1700$ is a natural stream (Mitchell Branch) that receives treated wastewaters from various treatment facilities, including K-1407-B Holding Pond, and K-1407-E and K-1407-F settling basins. Samples collected in June 1986 indicate the presence of chromium, lead, nickel, arsenic, and uranium in stream-bed sediments. The stream has a National Pollutant Discharge Elimination System (NPDES) permit at a point near its confluence with Poplar Creek. Since 1974 there have been occurrences in which permitted parameters exceeded the discharge limits.

The K-1407-B Holding Pond, which has been designated for interim RA, is located west of Building K-1420 and south of the K-1407-C Retention Basin. The pond consists of a 1.3-acre impoundment with a storage volume of $\sim 1.5$ million gal. K-1407-B was placed in operation in 1943 as a settling basin for neutralized cleaning solutions generated from the cleaning of nickel-plated steel pipes. This impoundment was used primarily for settling the metal hydroxide precipitates generated during the neutralization and precipitation of metal-laden solutions treated in the $\mathrm{K}-1407-\mathrm{A}$. neutralization unit. Contaminants include cadmium, chromium, lead, calcium, magnesium, various acids, nickel chloride, and ferrous chloride.

Interim RA will be a dirty closure consisting of filling the pond with $10 \mathrm{ft}$ of rock and overlaying rock with a clay cap.

The K-1407-C Retention Basin, which has been designated for interim RA, is a surface impoundment located north of the K-1407-B pond and northwest of the K-1420 decontamination building. The pond consists of $\sim 2.1$-acre impoundment with a storage volume of $\sim 4.5$ million gal. The impoundment was used primarily for the storage of potassium hydroxide 
scrubber sludge generated at the K-25 Site. In addition, metal hydroxide sludges removed from the K-1407-B pond were discharged to this impoundment beginning in 1973. The sludge is considered radioactive and hazardous.

In 1985, six monitoring wells were installed in the K-1407-C area. Well UNW-6 serves as the upgradient well providing background data for the K-1407-C Retention Basin, and the other five wells function as the point of compliance. After collection of five quarters of base-year background samples, a statistical analysis of the groundwater data was performed. Conductivity measurements were significantly elevated; some samples showed arsenic, barium, chromium, lead, and mercury levels sporadically above drinking water standards. Lead was elevated in the upgradient well with respect to the concentrations in the downgradient wells. Contamination in the upgradient well indicated that there are potential contaminant sources upgradient of $\mathrm{K}-1407-\mathrm{C}$. The contaminants detected in the wells are not believed to be attributable to $\mathrm{K}-1407-\mathrm{C}$.

Interim RA will be a dirty closure consisting of the installation of a modified RCRA cap.

\subsubsection{K-1413 OU}

The K-1413 OU is located in the main plant area directly across from Building K-25 at the intersection of 16 th Street and Avenue J. Practical components are a research and development building, a neutralization pit, two process drain pits, process drain lines from the pits to the K-1401 acid line, and vicinity storm-drain lines that once received the facility's process discharges. The K-1413 research and development facility operated from the 1950 s to 1981-82. Wastes include sodium and potassium hydroxides, uranium compounds, and acids such as sulfuric, hydrofluoric, nitric and hydrochloric. Organic acids, diethylene glycol, dibutyl ether, and metal fluorides of sodium, chromium, nickel, uranium, and copper would be in the discharges. Traces of mercury were sampled in the neutralization pit.

\section{$3.3 .5 \mathrm{~K}-1420 \mathrm{OU}$}

The K-1420 OU is located within the K-25 Site, between the Northeast Patrol Road and 15th Street. The OU consists of four practical components: wastewater process lines, an oil-storage yard, an incinerator, and a mercury recovery room.

During its history of operations, the K-1420 facility has performed uranium recovery, oil recovery, mercury recovery, cylinder cleaning, plating, decontamination of uranium enrichment process equipment, converter conditioning and recovery, feed-plant equipment cleaning and decontamination, and alumina leaching. Therefore, the K-1420 facility processed a wide spectrum of chemicals and uranium compounds, including TRUs. The K-1421 incinerator burned uranium-contaminated gloves, shoes, and oil sludges during its life cycle. The K-1420 Oil Storage Station handled contaminated oils.

\subsubsection{Area 2 Groundwater OU}

The Area 2 Groundwater unit covers a 320 -acre area roughly bounded by plant grid lines $\mathrm{S} 260+00 / \mathrm{S} 296+00$ and $2000 \mathrm{~W} / 4800 \mathrm{E}$. It is the potential receptor of 20 possible source locations. An RI is planned for ten of those units. Contaminants are primarily organics, including PCBs, but radioactive contaminants and some metals are also found. 


\subsubsection{K-1004 OU}

The K-1004 OU is located in the area northeast of the intersection of Avenue D and Fifth Street in the immediate vicinity of K-1004-J. Practical components include underground radioactive waste vaults, tanks, and two sets of recirculating cooling water ( $R C W)$ lines.

The K-1004-J vaults and K-1004-L underground storage tanks consist of six storage vaults and a 5500- and 750-gal storage tank. Beginning in the 1940s, radioactive materials, including uranium, plutonium, neptunium, californium, technetium, and cesium were stored in the vaults and tanks.

The K-1004-N RCW system served the K-1004-L Cascade Pilot Plant from the mid 1950s to 1984 . The system used a chromate/zinc/phosphate corrosion inhibitor until 1977 , when it was replaced by a phosphate treatment. The K-1004-N1 system provided secondary cooling to $\mathrm{K}-1200, \mathrm{~K}-1210$ and $\mathrm{K}-1225$ from 1975 to 1985 . The system used sanitary water treated with Dearborn 321 biocide, Dearborn 4622, and Zimmite Chemtrol 19. Both systems are now unused.

\section{$3.3 .8 \mathrm{~K}-1007$ OU}

The K-1007 OU is located in the southeast section of the plant. The OU consists of an area laboratory drain, the holding pond to which it flows, and a gasoline tank.

Wastes discharged into the K-1004 Area Lab Drain beginning in the 1940s are suspected to have included acetone, acetic acid, acetonitrile benzene, bromoform, cadmium, carbon tetrachloride, dichloropropane, ethanol, ammonium hydroxide, chloroform, chloric acid, chromates, diethylene glycol, dibutyl ether, ethylene glycol, Freons (all varieties), hexane, hydrochloric acid, hydrofluoric acid, hypophosphorous acid, isopropyl alcohol, mercury, methyl alcohol, methyl ethyl ketone, methylene chloride, nickel compounds, nitric and phosphoric acids, PCBs, photographic solutions, potassium dichromate, potassium and sodium hydroxides, pyridine, rhenium, sulfuric acid, technetium, tetrachloroethylene, toluene, trichloroethylene, tungsten, and uranium. The laboratory area facilities continue to operate. Beginning in the 1950s, the K-1007-P1 Holding Pond received wastes from the area lab drain, along with storm-water runoff.

K-1007 Gas Tank, with a capacity of 200 gal, was used from 1950 to 1986, when it was discovered to be leaking. The tank was removed following clean-up of the spill. Soil samples were collected around the spill area to determine the need for additional RAs. Data indicated that none was required.

\subsubsection{K-1064 OU}

The K-1064 OU is located northwest of Building K-25 on a peninsula formed by a bend in Poplar Creek. Practical units include groundwater, two cooling tower basins, and a drum storage and burn area.

The K-801-G and K-802-H cooling towers were built in the mid 1940s and used a zinc/chromate/phosphate treatment system from the 1950 s to 1977 . Both towers were demolished in the late $1970 \mathrm{~s}$, but a portion of $\mathrm{K}-801-\mathrm{H}$ was rebuilt and is in use. The $\mathrm{K}-802-\mathrm{H}$ basin is in use for firewater makeup. 
The K-1064 Drum Storage and Burn Area was used to store and burn waste solvents in the 1950s. From 1960 to 1983 , paint wastes, organic wastes, and radioactively contaminated waste oil, including PCBs, were stored at this location. Contaminants are primarily organics, radioactivity, and metals.

The operations conducted around Area 4 indicate that polynuclear aromatic hydrocarbons, heavy metals, and radioactivity may be contaminants of the groundwater.

\subsubsection{K-1410 OU}

The K-1410 OU is located between the southwest corner of Building K-25 and Poplar Creek. Practical components of the OU include a neutralization pit, waste paint accumulation area, groundwater, and a building formerly used for uranium decontamination, process equipment recycling and nickel plating.

Building K-1410 was used for receiving and emptying cascade traps and for uranium decontamination in the $1940 \mathrm{~s}, 50 \mathrm{~s}$ and $60 \mathrm{~s}$. From 1963 to 1979 , the building was used as a nickel plating facility. Wastes generated from uranium decontamination and recovery operations included nitric acid; organic degreasers including carbon tetrachloride, trichloroethylene, and perchloroethylene; MFL oil; and uranium compounds and TRU. Cleaning solutions were routinely discharged into the building process drains. Degreasers were occasionally discharged down the drains. Wastes generated from the plating process, and discharged into the K-1410 Neutralization Pit, include alkaline cleaners, acids, nickel sulfate, and fluoride.

Building K-1031, located west of the K-306-5 and K-306-6 process buildings and north of Building $\mathrm{K}-1410$, has been in operation since the mid 1940s. The building was originally used to clean spent traps from the diffusion cascade process buildings. In the early 1960 s, Building K-1031 was converted to a storage facility for paint and painting equipment. Beginning in 1980, the building was also used for paint mixing. Activity was discontinued in 1986. Oil-based paints, latex paints, zinc-based paints, lead oxide, chlorinated rubber-based paints, bitumastic-asphaltic tar, varnishes, shellacs, polyurethane, epoxies, enamels, glyptal, thinners, cleaning solvents, and uranium are the suspected contaminants.

The Area 5 Groundwater unit covers a K-25 area roughly bounded by plant grid lines $\mathrm{S} 25150, \mathrm{~S} 25650,3000 \mathrm{~W}$ and $2400 \mathrm{~W}$. The contaminants are primarily radioactivity and some metals.

\subsubsection{K-29 OU}

The K-29 OU is located at the southeast corner of the plant near Buildings K-27 and K-29. Practical components include the K-27 and K-29 RCW system and switchyard, a sewage treatment plant, and the area's underlying groundwater.

K-27 and K-29 RCW Lines and K-832-H Cooling Tower Basin were in use from 1945 until uranium enrichment activities were stopped in 1985. A zinc/phosphate/chromate system was used as a corrosion inhibitor.

PCB-contaminated oil is the only suspected contaminant at the K-732 Switchyard, which has been in operation since 1945 . 
The K-1203 Sewage Treatment Plant, located west of the K-27 process buildings, has been in operation since 1943. The Environmental Monitoring Station equipment at K-1203-B ensures compliance with the effluent limitations and monitoring requirement as set forth in the NPDES permit (TN 0002950). The effluent samples for dissolved oxygen, suspended solids, and $\mathrm{pH}$ are taken at the discharge end of the chlorine contact tank. Analytical data indicates that the concentrations of several metals detected in sampled sludge are above guideline values.

\subsubsection{K-33 OU}

The K-33 OU is located around Buildings $\mathrm{K}-33$ and $\mathrm{K}-31$ at the northwestern portion of the plant. Practical components include four cooling tower basins, their RCW lines, two swirchyards, and underlying groundwater.

K-33 OU cooling water systems and switchyards were in use from the 1950s until enrichment operations stopped in 1985 . Cooling water system corrosion inhibitors included zinc, phosphate and chromium. In addition, a biocide treatment used on the cooling towers likely produced a variety of zinc and copper salts. French drains were placed under the switchyards at construction, and skimmer pits to collect yard drainage were installed in 1980-81. PCB-contaminated oils are the only suspected contaminants for the switchyards.

Area 9 Groundwater unit is located on 185 acres in the northwestern corner of the plant, north and west of Poplar Creek. Contaminants are priunarily organic (possibly PCBs), but radioactive contaminants and some metals are frund as well.

\subsubsection{Area 10 OU}

Area $10 \mathrm{OU}$ consists of a contaminated burial ground, landfarm, holding pond, two construction waste disposal areas, and underlying groundwater. The OU is located northwest of the main plant.

K-1070-A Old Contaminated Burial Ground, northwest of Building K-33, was used for the disposal of several types of material from the 1940 s to 1976 . The burial ground contains about $35,575 \mathrm{ft}^{3}$ of uranium-contaminated material and $2430 \mathrm{ft}^{3}$ of thorium-contaminated material. Other material includes $\mathrm{UF}_{6}$ cylinders, beryllium chips, boron, radioactive $\mathrm{NaF}$, oil, rags, etc. The K-1070-A landfarm received $\sim 5000 \mathrm{ft}^{3}$ of Fuller's Earth between 1979 and 1985. The Fuller's Earth was laden with concentrated acids, sludges, and other degradation products from uranium enrichment cascade oil.

K-901-A Holding Pond received chromated, cooling-tower water blowdown and a variety of other wastes from barrels drained into the pond in the late 1950s. K-901 Waste Disposal Area and K-901-A Sanitary Disposal areas each received construction wastes beginning in the 1940 s.

\subsubsection{K-770 OU}

The K-770 OU includes a contaminated scrap metal yard and contaminated debris, two buildings used as part of a thermal diffusion plant in the 1940s, and a sewage treatment plant. The unit is located southwest of the main plant area at the Clinch River. Beginning operation 
times for the various subunits range from 1943 to the early 1960 s. The scrap metal yard and sewage treatment plant are still in operation.

The K-770 Scrap Metal Yard contains $-20,000 \mathrm{ft}^{3}$ of asbestos-containing metal along with waste materials contaminated with uranium, TRUs, mercury, and asbestos. Within the K-770 Scrap Metal Yard is Building K-726, which was used for storing PCBs. Suspected contaminants of concern in Buildings $\mathrm{K}-722$ and $\mathrm{K}-725$ are beryllium, mercury, asbestos, and uranium. In 1950, a transformer exploded at the K-709 switchyard, releasing PCBcontaminated oil onto the area. Sewage, which may contain traces of radioactive contaminants, is present at the $\mathrm{K}-710$ sewage treatment plant.

\subsubsection{K-1070 OU}

The K-1070 OU is located on the eastern edge of the K-25 Site. Practical components are a 22 -acre burial ground and three storage dikes.

Low-level radioactive and nonradioactive, nonhazardous waste materials and equipment were buried in large trenches at the K-1070-C/D Classified Burial Ground from 1972 to 1989. Wastes include hazardous chemicals and solvents, including a variety of organics. Heavy metals, including uranium and lead, were also buried here. The following materials were buried in the K-1070-D1, D2, and D3 Storage Dikes: trichloroethane, PCBs, paint waste, ethylene glycol, trichloroethylene, varsol, gasoline, methyl chloride, isopropyl alcohol, uranium-contaminated Freon, Vartex, methyl ethyl ketone, Dearborn 537, perchloroethylene, oil filters, Sorb-all and oil, Cimcool, sludge from garage wash racks, acetone, xylene, classified liquid, Rust Ban, tolyl triazole, scintillation waste, refrigerant oil, tributyl/phosphate, dioctyl phthalate, classified oil, Freon trichloroethane, methylene chloride, sulfonic acid, Mictobiotreatment, ethyl alcohol, classified materials (laboratory packs), paint thinner, hexane, penta-ether, Nutek, non-PCB solvents and cleaners, degreaser residue, absorbents, and sweeping compound.

\subsubsection{K-25 OU}

The K-25 OU, located on Avenue F near the center of Building K-25, consists of a dilution pit located outside Building K-1024. Beginning in 1945, the pit received acid/solvent solutions from the building process drain lines that once served the instrument maintenance shops. For the 1970-1985 period, the west wing of the building accommodated a centrifuge development laboratory operation. The pit is now in standby mode. The suspected contaminant is uranium.

\subsubsection{K-1417 Drum Storage Area}

The K-1417 Drum Storage Yard is a RCRA-permitted waste storage area. There are $\sim 78,000$ drums stored at K-1417 containing sludge from the K-1407-B Holding Pond and the K-1407-C Retention Basin. The sludge contains inorganic, organic, and radioactive contamination and was removed from the ponds during RCRA closure activities in 1988. Prior to storage at $\mathrm{K}-1417$, the sludge was either drummed or stabilized in a concrete grout mixture at the K-1419 Sludge Fixation Facility. A schedule for this area is not provided in Appendix C. 


\subsection{Y-12 OUs}

The Oak Ridge Y-12 Plant was built by the U.S. Army Corps of Engineers in 1943 as part of the Manhattan Project. The original mission of Y-12 was to separate the fissionable isotope of uranium $\left({ }^{235} \mathrm{U}\right)$ by the electromagnetic process. After World War II, the electromagnetic separation process was discontinued in favor of the more economical gaseous diffusion process.

Since the early years of Y-12 operations, the facility has developed into a highly sophisticated manufacturing and developmental engineering facility. It occupies $\sim 800$ acres and is located immediately adjacent to the city of Oak Ridge. The total work force consists of $\sim 8,000$ persons, including employees of ORNL.

Currently, Y-12 produces components for the various nuclear weapons systems in the national defense arsenal. A portion of this effort involves converting ${ }^{235} \mathrm{U}$ compounds to metal and the appropriate casting, rolling, and machining operations required to produce a finished product.

One of the major responsibilities of the Y-12 Plant is to provide engineering support to ORNL and to the gaseous diffusion plants located in Oak Ridge; Paducah, Kentucky; and Portsmouth, Ohio. Approximately 1000 ORNL employees are located at the Y-12 Plant, principally in three divisions: Biology, Fusion Energy, and Engineering Technology. The facilities used by ORNL personnel at Y-12 range from complex animal research laboratories to fusion-energy apparatus. Y-12 fabricates hardware for experimental programs conducted at ORNL and for other research and production operations. In addition, Y-12 supplies a variety of housekeeping and maintenance services to installation groups.

Over 100 contaminated areas have been identified at the $\mathrm{Y}-12$ Plant resulting from past waste management practices. All of these areas have been grouped ir,to OUs based $n$ priority and common assessment and remediation requirements. Nine OUs are made up of 31 units within the plant area and its surrounding environs.

The remaining 69 units have been grouped into a single OU, the Y-12 Study Area, and constitute lower priority units that will be investigated as PA/SIs. These units will be elevated into the appropriate OUs if the degree of contamination determined by the PA/SI warrants further conduct of an RI/FS.

Two OUs have been defined for groundwater contained within the Bear Creek and East Fork Poplar Creek hydrologic regimes. Groundwater will be investigated separately because of the overlapping nature of source plumes and the observation that most plumes share a common hydrologic unit for off-site transport. Also, many releases to groundwater are historical, and the resulting plumes are no longer likely to be associated with the original source. As the groundwater plumes are defined, they will be associated with sources to the extent practical.

\subsubsection{Upper East Fork Poplar Creek OU 1}

Upper East Fork Poplar Creek (EFPC) OU 1 consists of surface water runoff from the storm sewer system, and contaminated soil, shallow groundwater, and surface water associated with the Mercury Use Areas (see Appendix D, Fig. D.6). 
The storm sewer system consists of an extensive array of storm drains that gather runoff from the main plant area in catch basins located across the plant. The storm sewer network contains several miles of drainage pipes and culverts that range up to 72 inches in diameter. Upper EFPC begins underground at the west end of the Y-12 Plant, surfaces near the middie of the Plant, flows to the northeast along Bear Creek Valley, and exits the valley to the north within $\mathbf{0 . 5}$ mile of the plant. Upper EFPC is fed entirely from storm sewer system discharges. Direct surface water runoff from the pant production areas and groundwater seepage are additional sources of Upper EFPC flow. Because flow originates entirely within the Y-12 Plant, this OU focuses on evaluating sources of contamination in surface-water flow entering the storm sewer system.

From 1955 through 1963, a column-exchange process involving large quantities of mercury was employed to separate lithium isotopes. The Mercury Use Areas include buildings and other facilities that have been designated as possible sources of mercury contamination because of known, suspected, or presumed releases. The area of investigation includes the following buildings and adjoining areas: 9201-2, 9201-5, 81-10, 9204-4, 9202, 9733-1, 9733-2, and mercury flask storage areas and deflasking facilities. This OU will address soil, surface-water, and shallow groundwater contamination associated with these facilities. Surface-water sampling within the storm sewer systems together with soil sampling will be employed to identify contaminated areas. Shallow groundwater flow (i.e., influenced by building sumps) and contamination beneath the main process buildings will be characterized.

\subsubsection{Upper East Fork Poplar Creek OU 2}

The Upper EFPC OU 2 is the Abandoned Nitric Acid Pipeline, which was used between 1951 and 1983 to transport a waste stream made up of nitric acid and depleted uranium from Building 9215 to the S-3 Ponds for disposal (see Appendix D, Fig. D.6). The S-3 Ponds consisted of four unlined surface impoundments that underwent RCRA closure in 1988. The pipeline was constructed of 1.5- to 3.0-in. diameter stainless steel pipe and was buried at an average of $5 \mathrm{ft}$ below the ground surface. Numerous leaks have been determined with the earliest in 1951 at a weld about $350 \mathrm{ft}$ east of the discharge point.

The primary exposure pathways associated with the Nitric Acid Pipeline are soil contamination resulting from adsorption from leaked solutions, groundwater contamination resulting from waste solutions infiltrating to the groundwater table, and surface-water contamination resulting from groundwater seeps. Nitric acid and uranium are the primary contaminants of concern. Upper EFPC OU 2 will address soil contamination along the length of the pipeline as well as any surface water contamination. Groundwater contamination will be addressed in Upper EFPC OU 4.

\subsubsection{Upper East Fork Poplar Creek OU 3}

The Upper EFPC OU 3 consists of the S-2 Site; Coal Pile Trench; the Salvage Yard Oil and Oil/Solvent Storage Areas, Scrap Metal Storage Area, and Drum Deheader; the Machine Coolant Storage Tanks; and the Waste Coolant Processing Facility (see Appendix D, Fig. D.6).

S-2 Site. The S-2 Site is located in the southeastern area of the plant, south of Building 9720-32. It was used from about 1943 to 1951 to dispose of corrosive and toxic liquid wastes generated from Y-12 operations. The unit or iginally consisted of a $45-$ by $128-\mathrm{ft}$ unlined 
earthen reservoir that was $\sim 20 \mathrm{ft}$ deep. The reservoir was filled and stabilized when disposal operations ended. Heavy metals, including mercury in soil, are the contaminants of concern.

Coal Pile Trench. The Coal Pile Trench is a 50,000 $\mathrm{ft}^{3}$ earthen trench located beneath a coal pile west of the Y-12 Steam Plant (Building 9401-3). The trench was used to dispose of uranium and depleted uranium alloys, molybdenum, thiourea, carbon support forms, and other nonuranium materials. Because of the presence of the coal pile there is no access to the soil overlying the trench. The primary concern at this time is groundwater contamination from trench leachate, which will be addressed in Upper EFPC OU 4.

Salvage Yard. The Salvage Yard has been operating at the northwestern portion of the Y-12 Plant since 1950, when it was used solely for storage of uranium-contaminated and noncontaminated scrap metal. The total area of the Salvage Yard is $~ 2.2$ acres, of which about $75 \%$ is covered with scrap metal and other salvage materials. Waste oils containing PCBs were stored between 1980 and 1987 in two storage tanks located in the northern portion of the yard. The Salvage Yard Oil/Solvent Drum Storage Area was used to store waste oils contaminated with uranium and/or beryllium, and chlorinated organic solvents. The Salvage Yard Oil/Solvent Drum Storage Area had a capacity of about 3200 55-gal drums and was in operation from 1976 until its RCRA closure in 1988. The Salvage Yard Drum Deheader is also located in the northern portion of the Salvage Yard and has been in use since 1959. Soil contamination, resulting from uranium-contaminated salvage materials and solvents associated with the drum handling/storage operations, is of primary concern.

Machine Coolant Storage Tanks. Operations at the Waste Coolant Processing Facility have been ongoing since 1985 . The facility processes waste coolants from the plant which are transferred from within the plant and discharged into concrete unloading pits. Waste coolants can be contaminated with chlorinated organics, methyl ethyl ketone, cadmium, chromium, lead, and depleted uranium. The treatment area of the facility is fully contained inside concrete dikes; however, spills may have been associated with the unloading and storage areas.

\subsubsection{Upper East Fork Poplar Creek OU 4}

Upper EFPC OU 4 consists of the groundwater within the Bear Creek Valley drainage extending east from a topographic high near the west end of the Y-12 Plant (S-3 Waste Management Area) to East Fork Poplar Creek located near Scarboro Road (see Appendix D, Fig. D.7). Numerous sources of groundwater contamination exist within this area. Infiltration from the S-3 Ponds Waste Management Area (see Sect. 3.4.2) dominates groundwater contamination on the western hydrologic boundary. Groundwater quality is impacted in the eastern portion of the hydrologic regime by New Hope Pond, a RCRA Waste Management Area containing contaminated sediments, which was closed (capped) in 1988. In addition to potential groundwater contamination sources identified in Upper EFPC OUs 1, 2, and 3; the majority of the potentially contaminated areas making up the Y-12 Study Area OU (see Sect. 3.4) are within the Ujper EFPC hydrologic regime. Groundwater within the Upper EFPC hydrologic regime will be characterized and remediated as an OU distinct from the contaminated areas. This approach is warranted because (1) efforts to establish the horizontal and vertical extent of groundwater contaminant plumes from individual units indicate that the plumes are significantly intermingled, making assessment and remediation of individual plumes impractical, and (2) the units share a common exit pathway from the hydrologic system which is best addressed by a comprehensive approach. Primary contaminants within the Upper 
EFPC hydrologic regime are nitrate, volatile organic compounds (VOCs) (chlorinated solvents and petrochemical hydrocarbons), and radionuclides (uranium). Localized heavy metal contamination is also present.

\subsubsection{Bear Creek OU 1}

Bear Creek OU 1 comprises the following units associated with the Bear Creek Waste Management Area: S-3 Ponds, Oil Retention Ponds 1 and 2, the Oil Landfarm, and the Bear Creek Burial Grounds (see Appendix D, Fig. D.6). These were used until the 1980s as the primary area for the disposal of various types of hazardous and nonhazardous wastes generated at the Y-12 Plant.

Sanitary Landfill L Sanitary Landfill I received various types of nonhazardous waste from the Y-12 Plant. Waste disposal at Sanitary Landfill I was terminated in 1982, and the unit was graded, capped, and closed in 1983.

S-3 Site. The S-3 Site was constructed in 1951 and consisted of four unlined surface impoundments covering an area of roughly $400 \mathrm{ft}$ on each side with a total storage capacity of about 10 million gal. During its operation, up to $5500 \mathrm{gal} /$ day of effluent was pumped to the pond. The S-3 Ponds underwent RCRA closure in 1988. Primary contaminants were nitrates and uranium, with lesser concentrations of heavy metals and organic solvents.

Bear Creek Burial Grounds Waste Management Area. The Bear Creek Burial Grounds Waste Management Area, located on the southern slope of Pine Ridge $\sim 2$ miles west of the Y-12 Plant, comprises a series of waste disposal units covering an area of about 5000 by 3000 $\mathrm{ft}$. Each disposal unit consists of a series of trenches excavated to depths of 14 to $25 \mathrm{ft}$ below grade. The trenches received a variety of hazardous and nonhazardous solid and liquid wastes. All hazardous waste disposal operations were discontinued in 1981. Two of the disposal units are being closed as RCRA units. Oil Retention Ponds 1 and 2 were constructed to intercept seepage from burial trenches. Both ponds were RCRA-closed in 1990. A wide range of contaminants may have been disposed of in the Bear Creek Burial Grounds. VOCs in soil resulting from groundwater transport are of primary concern.

Oil Landfarm. The Oil Landfarm was used for the land application of waste oils and coolants that contained beryllium compounds, depleted uranium, PCBs, and chlorinated organic compounds. Disposal operations were discontinued in 1982. Final RCRA closure of the unit was certified by TDEC in December 1990.

Bear Creek OU 1 will determine the nature and extent of soil, sediment, and surface water contamination.

\subsubsection{Bear Creek OU 2}

Bear Creek OU 2 consists of the Rust Spoil Area, Spoil Area 1, and the SY-200 Yard (see Appendix D, Fig. D.6).

Rust Spoil Area. The Rust Spoil Area is located in Bear Creek Valley less than 0.5 mile west of the Y-12 Plant on Old Bear Creek Road. The Rust Spoil Area was used from 1975 to 1983 for disposal of spoil material generated during various renovation, maintenance, and

construction operations at the Y-12 Plant. Disposed material was periodically graded resulting 
in changes in topography and in filling of part of the Bear Creek channel. Approximately $100,000 \mathrm{yd}^{3}$ of nonuranium-contaminated construction spoils were disposed of at the unit. Small quantities of solvent- contaminated material and material containing asbestos, mercury, and uranium may have been disposed of in this area. Soil contamination is of primary concern.

Spoil Area 1. Spoil Area 1 is located near the southwest end of the Y-12 Plant, bounded by Old Bear Creek Road and West Patrol Road. Spoil Area 1 was used for the disposal of $\sim 100,000 \mathrm{yd}^{3}$ of nonhazardous, nonradiologically contaminated construction debris. Although plant controls eliminated the disposal of hazardous and radioactive wastes, past plant practices indicate that some of the construction material may have been contaminated with trace amounts of asbestos, mercury, beryllium, thorium, and uranium.

SY-200 Yard. The SY-200 Yard is a 200- by 300-ft aboveground storage area located adjacent to Old Bear Creek Road. Materials from several Y-12 and ORNL divisions included PCB transformers, lead shielding plates, and radioactively contaminated materials. Soil contamination is of primary concern.

\subsubsection{Bear Creek OU 3}

The hydrologic system at the Y-12 Plant has been subdivided into three distinct hydrologic regimes based on topography, surface-water drainage, and groundwater flow. The Bear Creek OU 3 consists of groundwater within the Bear Creek Valley drainage extending west from a topographic high near the west end of the Y-12 Plant (S-3 Waste Management Area) to the point where Bear Creek exits the valley near State Highway 95 (see Appendix D, Fig. D.7). Potential sources of groundwater contamination are being addressed in Bear Creek OUs 1 and 2.

Groundwater within the Bear Creek hydrologic regime will be characterized and remediated as an OU distinct from the contaminated areas. This approach is warranted because (1) efforts to establish the horizontal and vertical extent of groundwater contaminant plumes from individual areas indicate that the plumes are significantly intermingled, making assessment and remediation of individual plumes impractical and (2) the areas share a common exit pathway from the hydrologic system which is best addressed by a comprehensive approach. The primary groundwater contaminants in the Bear Creek hydrologic regime are nitrate, VOCs, radionuclides, and to a lesser extent, trace metals. Dense, nonaqueous-phase liquids (DNAPLs) have been discovered at a depth of $270 \mathrm{ft}$ below the Bear Creek Burial Grounds. The DNAPLs consist primarily of perchloroethylene, trichloroethylene, 1,1,1-trichloracetic acid, and high concentrations of PCBs.

\subsubsection{Bear Creek OU 4}

Bear Creek OU 4 consists of the Bear Creek sediments within the creek channel and floodplain. Bear Creek's headwaters are just west of the Y-12 Plant, and the creek flows westward through Bear Creek Valley until it exits near State Highway 95 (see Appendix D, Fig. D.7). Bear Creek has received contaminated surface water and groundwater discharges from past waste management practices in the Bear Creek Waste Management Area. Since these operations ceased in the mid 1980s and many of the disposal units closed, contamination of Bear Creek has been drastically reduced. Principal contaminants remaining in floodplain soils and sediments are PCBs, uranium, and cadmium. 


\subsubsection{Chestnut Ridge OU 1}

Chestnut Ridge OU 1 is the Chestnut Ridge Security Pits Hazardous Waste Disposal Unit located on the crest of Chestnut Ridge, southeast of the central portion of the Y-12 Plant (see Appendix D, Fig. D.6). Operated since 1973, the unit consists of a series of trenches that were used for the disposal of classified hazardous and nonhazardous wastes until December 1984 and November 1988, respectively. Ten major categories of unclassified wastes have been identified: acids, fiberglass, beryllium, biological material, debris, heavy metals, inorganics, organics, thorium, and uranium. Other classified waste forms are present. The unit was closed in 1988 in accordance with a TDEC-approved closure plan consisting of a low-permeability, low-maintenance cover over the trenches. Groundwater impacts from the disposal operations are the primary focus of this OU.

\subsubsection{Chestnut Ridge OU 2}

Chestnut Ridge OU 2 consists of the Filled Coal Ash Pond and McCoy Branch. The Filled Coal Ash Pond is situated within the McCoy Branch watershed about 0.5 miles south of the Y-12 Plant (see Appendix D, Fig. D.6). The pond was constructed in 1955 to serve as a settling basin for coal ash from the Y-12 steam plant. By 1967, the pond filled, spilling sediments directly into McCoy Branch. From 1967 to 1989, ash was carried within McCoy Branch to Rogers Quarry, about 0.5 mile downstream of the Coal Ash Pond.

Impacts to surface water, stream sediments, and groundwater from metals, including uranium and major ions, are of concern. Biomonitoring of aquatic organisms in McCoy Branch has shown a biological impact from the ash pond operations.

\subsubsection{Chestnut Ridge OU 3}

Chestnut Ridge OU 3 is the United Nuclear Corporation (UNC) Disposal Site located near the crest of Chestnut Ridge, in the southern portion of the Y-12 Plant (see Appendix D, Fig. D.6). Between June 1982 and November 1984, the UNC Disposal Site received 11,000 55-gal drums of sludge fixed in cement, 18,000 drums of contaminated soil, and 288 wooden boxes of contaminated building and demolition materials. The unit consists of a 1.3-acre excavation cut into the side of Chestnut Ridge and ranges in depth from 5 to $30 \mathrm{ft}$. The drums are stacked no greater than ten high following the contour of the excavation. Both the drums and wooden boxes are covered in polyvinyl chloride sheeting. Many of the drums and boxes have deteriorated, exposing their contents to the environment.

Groundwater transport modeling and risk assessment have indicated that nitrates and ${ }^{90} \mathrm{Sr}$ leached from the UNC Disposal Site present a long-term risk to exposure from groundwater. A feasibility study has been completed and identified a multilayer/multimedia, modified RCRA cap for long-term minimization of infiltration.

\subsubsection{East Fork Poplar Creek OU}

The Lower EFPC unit extends from the outfall at Lake Reality at the Y-12 Plant boundary downstream to the stream's confluence with Poplar Creek. Upper EFPC originates as Y-12 Plant wastewater and extends to the Lake Reality outfall. The Lower EFPC unit consists of the 23-km stream and an associated 550-acre floodplain (see Appendix D, Fig. D.8). 
As a result of the loss to the environment of contaminants associated with lithium processing operations at the Y-12 Plant near Oak Ridge, Tennessee, EFPC became contaminated with me:cury and trace levels of other metals, organics, and radionuclides. Since 1953, as much as 2.4 million pounds of mercury are thought to have been released. Approximately 75 metric tons of this material may still be in the floodplain soils.

The Sewer Line Beltway was constructed by the city of Oak Ridge in 1982-1983 and contains over 10 miles of sanitary interceptor sewers and force mains. In certain instances, EFPC floodplain soils were used to provide topsoil. No records were kept to document the backfill procedures and locations.

\subsection{CLINCH RIVER OU}

The Clinch River RI focuses on the portions of the Clinch and Tennessee rivers that may have been adversely affected by contaminants released from the mid 1940 s to present from the DOE ORR. The Melton Hill Reservoir and the Clinch River, downstream from Melton Hill Dam, form the southern and eastern boundaries of the ORR. The Clinch River enters the Tennessee River system of multipurpose impoundments near Kingston, Tennessee, $34 \mathrm{~km}$ downstream from the Oak Ridge complex. Watts Bar Reservoir is located on the Tennessee River just below its confluence with the Clinch River and is the first impoundment downstream of the ORR. This WAG/OU/study area includes Melton Hill Reservoir, the Clinch River (from Melton Hill dam to Kingston), and the Watts Bar Reservoir (see Appendix D, Fig. D.9).

The contaminants released from the ORR originate from research, industrial, and waste disposal activities conducted at ORNL, Y-12, and K-25. The contaminants released from these facilities include a variety of radionuclides, metals, and organic compounds. Some liquid wastes are discharged to streams on the ORR, which drain into the Clinch River; however, much of the water-borne contamination is derived from seepage into the shallow groundwater from old waste-storage pits and trenches. The contaminants of concern in the river/reservoir system were determined by preliminary human-health-risk screening using a variety of exposure pathways and nonconservative screening. PCBs were identified as contaminants of concern through fish ingestion. Arsenic, chromium, mercury, selenium, zinc, ${ }^{137} \mathrm{Cs}$, and ${ }^{60} \mathrm{Co}$ constitute a risk only if deep-channel sediments are dredged and dredged spoils are placed on land. 


\section{PROGRAMMATIC UNITS}

\subsection{ORR DECONTAMINATION AND DECOMMISSIONING (D\&D) PROGRAM}

The D\&D Program activities on the ORR consist of five individual programs that are coordinated/integrated (along with the Paducah and Portsmouth D\&D programs) through the DOE-OR ER Division, with the Martin Marietta Energy Systems, Inc., Central D\&D Program Office as integrating contractor. The five programs are the K-25 Site D\&D, K-25 Site Gas Centrifuge Enrichment Facilities, and select facilities from ORNL, Y-12, and ORAU. D\&D, including surveillance and maintenance, provides for the safe caretaking and disposition of retired, DOE-owned nuclear facilities.

The D\&D program on the ORR consists of 70 facilities at the K-25 Site (including 14 gas centrifuge enrichment structures), 29 shutdown projects at ORNL, Building 9201-4 at Y-12, and some possible animal facilities on the south campus of ORAU. The facilities currently included in the D\&D program are varied, including mercury-contaminated equipment and structures, hot cells, experimental reactors, and uranium enrichment equipment and structures. The various facilities have a wide variety of contaminants, such as PCBs, friable and nonfriable asbestos, chlorofluorocarbons, chromates, lubrication oils, miscellaneous RCRA materials, uranium, and other radionuclides.

Although some of the contaminants cause the program to be driven by specific regulations under RCRA, the Toxic Substances Control Act, or FFA/LG compliance, the program is primarily driven by DOE orders. Funding for the ORR D\&D program in FY 1991 is $\sim \$ 50$ million. Approximately $60 \%$ of the funding is utilized for the surveillance and maintenance necessary to preserve an acceptable level of health and safety conditions for the employees and the general public and also to acceptably protect the environment. The remaining funding is used for actual removal actions for asbestos, PCBs, and other hazardous materials; for selective decontaminations; and for developing plans and strategies for longterm decommissioning actions. Budget levels are projected to increase to nearly $\mathbf{\$ 8 0}$ million in FY 1992, over $\$ 90$ million in FY 1993, and over \$135 million in FY 1994. Ultimately, the decommissioning of the ORR will cost in the billions of dollars.

Typically, the D\&D program and the RA program activities are managed independently, but for budgeting and strategic planning they are integrated into the overall ER Program. For example, some D\&D facilities were the sources that contaminated some of the RA units. A specific example of this is the mercury contamination at the Y-12 Plant and in the city of Oak Ridge. The processing facilities that used mercury are currently part of the D\&D program. In other cases the level of contamination of soil beneath a D\&D facility may be unknown; when the building is demolished by the D\&D program, a remaining contaminated area may have to be added to the RA program. 


\subsection{WASTE MANAGEMENT PROGRAM}

\subsection{Overview}

The ER Waste Management (WM) Program provides centralized management, program planning, procedure development, and funding to ensure ongoing support in a consistent manner for the activities associated with the generation of ER waste. Some specific objectives of the ER WM Program are as follows:

- Achieving regulatory compliant treatment, storage, and disposal capabilities

- Preplanning WM project needs

- Compliance with waste certification

- Record keeping

- Program controls over cost and schedules

An ER Program WM plan is being prepared which will outline the areas where program guidance must be established. Major areas that will receive specific guidance are

- WM planning requirements

- Organizational roles and responsibilities

- Cost, schedule, and program controls

- Waste minimization programs

- WM technology demonstrations

- WM facility design and construction

- WM operations

- Waste certification programs

- WM regulatory compliance

- WM health and safety programs

- WM quality assurance (QA) programs

The ER Program WM plan will also define responsibilities and interfaces for program participants in the areas of planning, facility operation, facility design, and policy oversight.

ER Program activities are regulated and controlled through a myriad of federal and state regulations. In addition, the following DOE orders are in place to specifically direct the WM component of the ER Program:

- DOE Order 5820.2A, "Radioactive Waste Management"

- DOE Order 5400.3, "Hazardous and Radioactive Waste Program"

\subsection{Information Management}

Other areas that are critical to the mission of integration and obtaining consistency with all ER Program participants are information management and decision support/ communication to field and facility operations. The ER Program is developing a central information management system. The system will be a mechanism and management tool for compiling waste information to coordinate waste-storage requirements with the Central Waste Management Division at the ORR, as well as documenting, disseminating, and reporting other waste information and requirements. 


\section{Waste Management Funding and Responsibilities}

The ER Program is a generator of wastes much the same as other DOE programs. Like other DOE organizations, the ER Program is responsible for the management and disposition of the wastes that it generates. The ER Program may treat, store, or dispose of ER waste on its own or it may, upon coordination with the Central Waste Management Division, utilize existing or planned DOE facilities under other DOE Program responsibilities for treatment, storage, and disposal (TSD). The ER WM costs and budget requirements associated with the program will be documented in the appropriate activity data sheet (ADS) used to provide planning information to Congress. WM costs from generation through ultimate disposal shall be included, and interfaces with TSD facilities shall be identified.

\section{TSD Capacity and Future Impacts}

RI, RA, and D\&D activities are now under way at a signinicant pace at all of the DOE-OR installations. Stemming from the rapid increase in waste generation volumes from the ER Program activities and the relatively small amount of excess capacity existing in individual plant TSD units, there are increasing waste generation versus capacity disconnects occurring throughout the system. Specific examples of such problems include the recent requirement for slowdown of $\mathrm{RI}$ activities at Portsmouth because of the lack of mixed-waste storage space, and the need for establishment of temporary storage at the Kerr Hollow Quarry remediation unit because of the lack of available hazardous and mixed-waste storage capacity at the Y-12 Plant. These examples are symptomatic of the much larger concerns that exist over the planned major RI, RA, and D\&D projects that are expected to be producing waste in the coming year. Resolution of these very real disconnects has had to be handled on a case-by-case basis because of a lack of coordinated waste generation estimating, TSD capacity planning, and project-specific WM planning.

Actions are being taken by the ER Program to provide the needed up-front project planning and overall waste estimating needed to avoid the TSD capacity disconnects. All program participants are being required to develop project WM plans to outline the expected waste quantities and types requiring TSD. These plans must be reviewed and approved by the respective WM organizations and the ER Program prior to approval of the project startup. To get some overall estimate of the magnitude of the WM needs for the ER Program over the 5-year planning horizon (and beyond, if possible), a task force has been established to develop waste generation estimates for both RA and D\&D units at all DOE-OR facilities. This estimating exercise will provide baseline ER Program waste estimates for RI, RA, routine D\&D facilities maintenance and surveillance, and D\&D removal actions through the budget planning cycle and beycnd. Documented estimating methodology is being entered into a WM assessment model for archival and use in performing generation-versus-capacity evaluations. The baseline waste generation estimates have been developed and loaded into the working model, and periodic updates will be conducted as needed.

\subsubsection{Management of Investigation-Derived Wastes}

Past management of investigation-derived wastes (IDWs) has been tailored after production waste management because of the relatively small volumes. However, increased IDW generation, coupled with the off-site shipment moratorium, shrinking TSD capacity, and limited analytical capacity requires a change in IDW management. The revised IDW management entails maximizing treatment and disposal of IDW within the area of 
contamination consistent with EPA guidance. Successful IDW management minimizes costs while not increasing any personal or environmental risks at the waste area. Specific IDW management plans will be outlined in the RFI/SI plans submitted to the regulators.

\subsection{RESERVATION GROUNDWATER PROGRAM}

\subsubsection{General Description of the Groundwater Program}

The Energy Systems Groundwater Program Office (GWPO) was established in May 1991 as a means of providing a consistent approach for all groundwater programs at the five plants operated by Energy Systems for DOE. The overall goals of the GWPO are

- To fully comply with all DOE orders and federal and state statutes pertaining to groundwater

- To develop a groundwater program that is technically sound, consistent among the Energy Systems facilities, and responsive to the needs of DOE and the regulators

- To establish a mechanism for technical support to the ORR facilities which addresses fundamental principles of groundwater flow and contaminant migration and the integration of this information at the installation level to the various monitoring programs

The GWPO interfaces with each of the ORR installation Groundwater Protection Program Managers (GWPPMs). The GWPPM is the single point of contact at each facility for all activities related to groundwater. The GWPPM has established a matrix organization that includes those functions associated with groundwater (ER, compliance, WM, engineering, QA, field sampling, and laboratory analysis). Any activity related to monitoring well installation (location, depth, or purpose), groundwater sampling, analyses, data interpretation, and reporting is within the purview of the GWPPM. Programmatically, the GWPPM reports through the GWPO.

An essential component of the Energy Systems groundwater program is the support provided to the GWPPMs by the Oak Ridge Hydrologic Support Program (ORHSP). ORHSP is made up of three components: technical support, environmental surveillance, and the ORR hydrologic and geologic studies (ORRHAGS). For the technical support function, ORHSP has assigned a technically qualified hydrogeologist to work with each GWPPM. The hydrogeologists are to assist the GWPPM in all technical questions related to groundwater and serve as a conduit for communicating technical guidance related to groundwater monitoring programs.

The environmental surveillance component of ORHSP is established to ensure consistency and technical sufficiency in the environmental surveillance activities mandated by DOE Order 5400.1. Environmental surveillance refers to monitoring activities related to perimeter- and exit-pathway monitoring which are designed to ensure that contaminants associated with groundwater are not crossing ORR boundaries and that the location and extent of potential contaminant migration pathways are well defined. Environmental surveillance for the ORR also includes privately owned wells located beyond the boundaries of DOE-owned land which are used for drinking water. For the ORR, ORNL is responsible 
for implementing the environmental surveillance program. Oversight and technical guidance is provided by ORHSP.

ORRHAGS is a component of ORHSP that is responsible for developing a fundamental understanding of the underlying principles that control groundwater flow and contaminant migration on the ORR. These studies include a revision of the geologic map for the ORR, evaluation of background hydrochemical properties of groundwater, and exploration of the interaction of the hydrogeologic regime on contaminant migration. Technical support personnel of ORHSP are important in communicating to ORRHAGS the technical problems at each installation that need to be addressed and in working with the GWPPMs to understand and implement the results of ORRHAGS technical studies into installation groundwater programs.

\subsection{Activities To Be Performed}

The GWPO has several key activities that are being pursued:

- Establishment of a consistent set of plans, procedures, and specifications that will implement the groundwater programs at each facility. The plans and procedures for each facility will be identical, where possibie, and different, where appropriate, based on unique features of the particular facility. However, all plans and procedures will utilize a consistent strategy.

- Oversight of establishment of a consolidated data base for groundwater data (well construction information, geologic data, hydrochemical results, hydraulic testing results, etc.) and development of consistent data verification and validation protocols. In the interim, it is essential for the GWPPMs to develop a facility-specific, well inventory system as a management tool. These data will reside in the Oak Ridge Environmental Information System (OREIS).

- Development of a consistent strategy for groundwater monitoring activities (e.g., environmental surveillance and a comprehensive groundwater monitoring plan for each plant).

\subsubsection{Monitoring Data Being Collected}

Groundwater monitoring activities for the ORR fall into two categories: effluent monitoring and surveillance monitoring. Effluent monitoring includes those activities that take place at specific waste disposal areas and contaminant source areas. Groundwater samples that are collected for effluent monitoring are analyzed for a variety of water-quality and facility-specific contaminant parameters. The following are included in effluent monitoring for groundwater:

- RCRA interim status or RCRA-permitted facilities

- 3004(u) units

- CERCLA units

- Active WM facilities

- Underground storage tanks 
As noted, surveillance monitoring for the ORR is directed toward monitoring groundwater along plant facility boundaries (perimeter monitoring), especially in those regions where groundwater flow pathways could potentially result in contaminant migration across the boundaries (exit pathways). In addition, selected, privately owned wells are monitored and constitute a culinary drinking water program. In general, the list of analytes included in surveillance monitoring is restricted to a relatively small number of indicator paramete $s$ that are customized to the specific region being monitored. Surveillance monitoring also includes activities that each plant believes are necessary to supplement their overall monitoring program but are not specifically required by DOE Order 5400.1 or regulations governing effluent monitoring areas. These additional monitoring activities constitute a "best management practice."

\subsubsection{Future Activities}

Some activities will be addressed by the GWPO in the future:

- Completion of comprehensive groundwater monitoring plans for each plant in the ORR

- Completion of the consolidated data base

- Evaluation and preparation of plans and procedures required to implement the groundwater monitoring program

One of the major challenges of the GWPO is to oversee development of comprehensive groundwater monitoring plans for each of the Energy Systems ORR facilities. Significant difficulties must be overcome to accomplish this goal. For example, three major programs at each plant are responsible for collecting groundwater data: Environmental Compliance, ER, and WM. Data obtained by these programs differ somewhat in the collection and evaluation methodologies used. The intrinsic value of comprehensive monitoring plans and associated mechanisms for evaluating and reporting the results of all groundwater programs at each facility is recognized, but that goal has not been attained yet. Although defining firm schedules for completion of comprehensive monitoring plans is not possible at this time, the objective is to have made significant progress toward this target by the end of FY 1992.

The activities and completion schedule for the consolidated data base are presented in Sect. 4.6.

A comprehensive review of the applicable plans and procedures for implementing a consistent groundwater program will begin before the end of FY 1991. It is anticipated that these plans and procedures will be completed by the end of FY 1992.

\subsection{WELL PLUGGING AND ABANDONMENT PROGRAM}

The objective of the well and borehole plugging and abandonment (P\&A) program is to ensure that all wells and boreholes no longer in use are sealed to eliminate conduits that could allow (1) contamination from the ground surface to reach the water table or (2) for movement of contaminants between aquifers. In addition, P\&A tasks will also remove casings that could provide an obstacle to construction or installation of impermeable caps on areas to be remediated. On the ORR, there are over 2300 known wells and boreholes that must be evaluated for possible P\&A. At ORNL, the P\&A program has been divided among the 
following areas: WAG 5, WAG 6, WAG 10 (hydrofracture wells), and all other WAGs. The WAG 5 and 6 P\&A programs will support and are integrated with closure activities at those facilities. WAG 10 P\&A will be initiated with high-priority wells that will be examined and stabilized as needed in the near term. All remaining ORNL wells will be addressed via an Interim ROD. Those wells that remain active or are retained for later use will be incorporated into an ongoing inspection and maintenance program, with limited P\&A actions as needed.

At the Y-12 Plant, monitor wells and piezometers have been and will be plugged and abandoned in accordance with established procedures. The general situation is one of ongoing, routine maintenance of a monitoring network where there is no legacy of older wells or boreholes. At present, a planning document is being prepared which will maintain the anticipated schedule for wells to undergo P\&A at the Y-12 Plant.

At the K-25 Site, wells or boreholes that are damaged, unusable, or no longer needed are identified by the GWPPM, in concert with requests from managers of other plant programs involving construction or closure activities. An annual schedule is maintained by the installation GWPO, and annual activities are documented. As is true for Y-12, the K-25 program is primarily one of ongoing maintenance of the wells network and does not include a significant legacy from past operations.

In general, P\&A projects are coordinated with RI/FS tasks and unit closure. The RI/FS provides field verification of well inventory data and supports the decisions for wells or boreholes that will be abandoned. In preparation for construction or capping as a part of unit remediation, wells are evaluated for P\&A action, and the P\&A process is conducted as a step in implementing overall unit closure or restoration. Where needed, wells that are abandoned are replaced to ensure postclosure monitoring system integrity.

\subsection{ANALYTICAL LABORATORIES PROGRAM}

ORR analytical chemistry requirements are ensured by a number of different sources of analytical support. These include internal laboratories, subcontracts for specific analytical services, and general-order subcontractors who are assigned specific tasks.

Each of the three ORR installations have analytical laboratories. These laboratories are responsible for the analytical needs of their facility programs. The services they offer are appropriate not only for the products produced by their plant but also for other facility requirements such as environmental, WM, industrial hygiene, health physics, maintenance, utilities, etc. When the facility laboratory does not offer a service, is not certified in an area where certification is required (such as a drinking water analysis), or does not have the internal capacity, the samples are sent by them through the Analytical Project Office (APO) to the other facility laboratories or to outside subcontractor laboratories.

The APO was formed in the spring of 1991. It is chartered to coordinate the overall analytical workload for the programs that are not facility specific. These programs included ER and the associated D\&D Programs, and WM. The APO serves the various facility laboratories by helping to level their analytical workload overflows through the placement of analytical work with the facility laboratories and at outside commercial laboratories. The office is responsible for the analytical subcontracts needed to accomplish that work and to ensure 
that the appropriate QA activities are carried out concerning the laboratories it uses. The office will coordinate the establishment and maintenance of standards which lead to transparency of analytical data and consistency of analytical procedures in programs. Functionally, the APO contains components of

- Program management

- Contracting and contract management

- Scheduling and cost analysis

- QA/quality control (QC) coordination

- Analytical chemistry, including organic, inorganic, and radiological

- Data management

- Prioritization

It also coordinates the Environmental Surveillance Procedures Validity Control Program.

The APO reviews project plans, sampling and analysis plans, and task orders which contain analytical support requirements. Its staff or designated alternates serve as members of the project teams during the planning of projects and assist in the formulation and definition of project requirements using the dated quality objective process. Staff coordinate for the projects to obtain the appropriate level of analytical service and data reports required to meet the data quality objectives.

\subsection{ENVIRONMENTAL DATA MANAGEMENT PROGRAM}

The primary goal of data management for the ER Program is to establish a system that will provide consolidated, consistent, and well-documented data and data products to support ER activities on the ORR. The system, referred to as the OREIS, will be used to manage, process, and report consolidated environmental data gathered by various facilities, programs, and projects on the ORR and will replace a complex of independent systems and data bases currently in use. The data management program will establish standards, policies, and procedures for ER Program data activities to ensure improved documentation and reliability of the data and to allow for integrated multidisciplinary ER Program assessments.

The following are the three primary tasks of the data management program and the FY 1992 activities associated with each.

1. Defining, implementing, and evaluating a consolidated environmental data base for all ER Program-related data, as described in the FFAIAG.

- Determine data base contents and structure.

- Consolidate data on wells and groundwater as the first phase of the data base.

- Resolve differences in documenting and reporting data from various sources.

- Expand the data base to include all environmental media (e.g., air, water, soil, and biota). Environmental compliance data relevant to ER Program activities will be included during lacer stiges of development. 
2. Creating, maintaining, and updating the OREIS.

- Establish and evaluate the prototype for OREIS. The prototype is currently under development and is expected to be ready for testing by October 1991. The prototype will include functions for data query, data export, graphics, statistical analysis, report generation, and Geographical Information System analysis.

- Develop a user interface. The interface will allow access to any combination of available functions.

3. Developing and implementing standards, policies, and procedures for ER Program data-related activities.

- Review existing standards, policies, and procedures relevant to ER Program data activities. Possible sources include Energy Systems, DOE, EPA, TDEC, and subcontractors.

- Develop a data management plan to include standards, policies, and procedures for overall data management activities. The Data Management Plan will be the primary reference document for specific ER Program projects.

The data management program provides technical coordination of these three tasks. ER Program staff and environmental monitoring staff will provide technical input and review to ensure the utility of the data management program to the overall ER Program. Next year's developments will be presented and discussed with regulatory agencies. 


\section{DATA QUALITY OBJECTIVES}

Data quality objectives (DQOs) are both qualitative and quantitative statements that specify the quality of the data required to support decisions during the RA activities. Information obtained from historical and operational investigations is used as the foundation for the sampling and analysis plans. In turn, the data generated from the actual site investigations are used to determine further sampling and analytical needs or to make decisions concerning potential remediation. During each of the steps of the process, data of some sort are used along with assumptions concerning that data's validity and representativeness. To ensure that data generated during the investigatory process are of an adequate quality and quantity, DQOs must be determined prior to proceeding to the next step of the process. DQOs must be established for sample collection, analysis, and data evaluation and should be integrated with project planning.

The establishment of DQOs is a three-stage process involving (1) identifying decision types, (2) identifying data uses/needs, and (3) designing an adequate data collection program. The ER Program uses multidisciplinary teams to develop the RI work plans and to evaluate the data. The needs and uses of the data by each of the specialists (chemists, statisticians, geologists, etc.) on the teams are built into the data collection program.

\subsection{DQOs AND SAMPLE COLLECTION}

The collection of media-specific samples is the primary mechanism for determining the nature and extent of contamination at RA units. Therefore, DQOs must be established for the collection of samples to ensure that the appropriate QA/QC procedures are implemented in the field. In general, most sampling and analytical plans for the ORR reference the Environmental Surveillance Procedures Quality Control Program (Kimbrough et al. 1988). This document contains the protocol for the collection, preservation, and handling of all types and varieties of samples. The DQOs for sample collection should be stated in each sampling and analysis plan and in each installation-specific QA project plan.

\subsection{DQOs AND SAMPLE ANALYSES}

The quality of the analytical data used in the RI is only as accurate and precise as the analytical method.allows it to be. Therefore, it is imperative that the appropriate analytical techniques be identified in the sampling and analysis plans and that those needs are made clear in the statement of work for the analytical laboratory. A chemist will work in conjunction with the RI team to ensure that the data quality needs of the data users are taken into consideration during the implementation of the analytical procedures.

\subsection{DQOs AND DATA EVALUATION}

\subsubsection{Statistics}

Statistical DQOs will be identified during the preparation of the sampling and analysis plans by a qualified statistician. These data needs will be incorporated into the development 
of the sample collection and analytical program. Appropriate laboratory QA/QC procedures must be implemented to ensure that the required analytical duplicates, replicates, and qualifiers were utilized and that the data package is complete.

\subsubsection{Risk Assessment}

The purpose of a risk assessment is to provide interested parties (managers, regulators, workers, and the general public) with an evaluation of the human and environmental health threats posed by hazardous waste areas. Risk assessment is a four-stage process that transposes/converts specific contaminant data (collected from sampling efforts) into a single number that can be compared directly to risk-based standards. Data collection/evaluation is the first stage of this process. During this stage, analytical and other specific data are used to characterize the nature and extent of contamination. The second stage, an exposure assessment, involves the calculation of exposures based on the contaminant concentrations estimated from the analytical data, fate and transport models, and information collected on the demography and behavior of receptor populations. The third stage, toxicity assessment, involves the collection of information concerning the toxic characteristics of each contaminant. The results of the toxicity assessment are combined with the exposure estimates to quantitatively or qualitatively evaluate the potential risks to human and environmental health posed by each contaminant of potential concern at a unit in the fourth stage, risk characterization.

To derive a reliable estimate of exposure for use in the risk characterization stage, it is essential to accurately determine representative constituent concentrations in the respective contaminated media at the unit. For example, consider estimating exposure from the ingestion of chemicals in drinking water. Exposure would be calculated using the following equation:

$$
\text { Exposure }=\frac{R C \times I R \times E F \times E D}{B W \times A T}
$$

where exposure is in milligrams per kilograms per day and

$$
\begin{aligned}
& R C=\text { representative concentration in water }(\mathrm{mg} / \mathrm{L}), \\
& I R=\text { ingestion rate }(\mathrm{L} / \mathrm{d}), \\
& E F=\text { exposure frequency (d/year), } \\
& E D=\text { exposure duration (years), } \\
& B W=\text { body weight, } \\
& A T=\text { averaging time (period, in days, over which dose is averaged). }
\end{aligned}
$$

With the exception of the representative concentration, all of the variables in the above equation tend to be estimated by generic values recommended by EPA. Toxicity values for a given chemical are also constant across hazardous waste areas. The representative concentration is entirely area specific and is probably the most important variable used to determine the threat to human and environmental health posed by individual hazardous waste areas. A representative concentration cannot be derived without reliable analytical data. 
To ensure that risk assessment DQOs are established and incorporated into the investigation process, the Risk Analysis Section of the Energy Systems Health and Safety Research Division will serve in the capacity outlined in the April 4, 1991, letter from Robert C. Sleeman, Director of the DOE-OR ER Division, to Lanny D. Bates, Director of the Energy Systems ER Division (Sleeman 1991). Attached to this letter was the approved interim policy guidance for "Environmental Restoration Risk Assessment Initiation, Implementation, and Interaction," which defined the roles and responsibilities for all organizations and individuals involved in the DOE-OR ER risk assessment activities. As stated in this policy guidance, the purpose was

to define the role of risk assessment in the ORO Environmental Restoration Program ... and identify responsibilities for developing and implementing this role, and define the line and matrix interactions needed for implementation of consistent risk assessment policy and approach in the Environmental Restoration Division.

This policy established the position of the Risk Assessment Coordinator and called for the organization of the Central Risk Assessment Council to "provide technical expertise and support to the Risk Assessment Coordinator." The Central Risk Assessment Council is composed of a multidisciplinary team of ER-Program-associated personnel [designated Risk Assessment Team Leaders (RATLs)] and Energy Systems personnel not specifically associated with an ER program who have expertise in the following areas: human health risk, ecological risk, toxicological information and data bases, risk model validation, sensitivity/uncertainty analyses, and risk assessment project implementation. Activities of the council include the following:

- Provide advice and guidance on appropriate risk assessment methodology and procedures

- Develop appropriate methods, procedures, models, and/or data needed to fulfill risk assessment needs

- Provide appropriate review of ER Program risk assessment implementation

- Support risk assessment needs through the research and development of critical data gaps

Prior to the initiation of the characterization phase at a unit, the RATL for that facility should be contacted to ensure that risk assessment data needs are included in the initial characterization phase. The risk assessment data needs will be succinctly stated within the sampling analysis plans as DQOs. RATLs are available to provide support to each of the facilities and are required to be functioning members of subcontractor teams that are performing risk assessments on the ORR. 


\section{PRIORITIZATION}

\subsection{OVERVIEW}

The Parties intend to move through the study and cleanup process as efficiently and quickly as possible, while protecting human health and the environment. Because so many problems must be addressed at the ORR and resources are limited, priorities must be established to ensure that the most serious threats to human health and the environment are dealt with first.

OUs are classified in this process as having high, intermediate, and low cleanup priority. The high priority is based upon high potential for exposure to humans, the environment, and any cleanup required to fully study and address other OUs. Intermediate priority is assigned to those units with moderate potential for exposure to humans and the environment and for units with potential for recontaminating other OUs. Low priority is assigned to all other units.

Appendix $\mathrm{C}$ reflects the current ORR OU ROD schedules and prioritizations. The schedules provided in this document are the best estimate of the Parties at this time. In cases where investigation work has not been initiated, the schedules reflect generic scheduling time frames. There are many factors that could cause these projected schedules to be re-evaluated and changed. The Parties will continue to address the more immediate problems while also identifying and implementing permanent remedies. Not reflected in these OU ROD schedules are the interim actions that can/will be identified as the PASI activities and field activities at the OUs progress. Interim actions, by definition, will be high priority.

\section{PRIORITIZATION PROCESS}

In January of each year, ER Program staff begin budget planning for the fiscal year that will begin two years later. For example, budget preparation for FY 1994 will begin in November or December 1991. ER program managers and staff prepare ADSs to support all ER projects planned. ADSs define the projects and outline work to be completed on a multiyear schedule. Budget requirements for each year's activities are also estimated. ADSs are initiated or updated each year to reflect changes in work plans resulting from changes in previous year funding, new discoveries, regulatory requirements, etc.

ER program managers and staff describe activities from the ADSs to be performed during the budget year. These activities are then prioritized by installation ER Program staff using a scoring and weighting system.

Each activity is evaluated in five areas: human-health risk, environmental impacts, regulatory obligations and other commitments, program impacts, and negative socioeconomic impacts. The activity receives a score from one to five in each category; five represents the most extreme adverse effect for the category.

Preliminary activity scores are scrutinized in a peer review meeting attended by ER program managers and staff within the DOE-OR domain. Activity scores are adjusted in this meeting to ensure consistency and relative integrity of scoring between the ORR programs. 
Initial weights (or measures of importance) are assigned to each criterion. These weights are the same as those agreed upon as a result of the previous year's review. Scores for each criterion are multiplied by the criterion weight, giving a weighted score. The weighted scores are totaled for each activity, and the activities are prioritized by their total scores. The activity with the highest total weighted score has the highest priority.

When the prioritization process begins for the ER program managers, public workshops are scheduled to discuss ORR-specific activities. Attendees at these workshops include members of the public, public officials, EPA representatives, and state regulators. These workshops provide background information on the proposed list of activities and on each individual ER program in general. The members of the public, along with the ER program managers, evaluate each activity in the five areas of human-health risk, environmental impacts, regulatory obligations and other commitments, program impacts, and negative socioeconomic impacts.

The ER program managers then use the results from the public workshop as a guideline for prioritizing the activities.

In February or early March, a public meeting is held to review the prioritization process and to present the individual $O U$ activity prioritizations for final review. Following the presentations, the meeting attendees have an opportunity to ask questions of the ER program managers and make comments regarding the prioritization plan. The priority rankings, which can be modified based on public cominents, are then finalized and used as the basis for determining budget needs.

The prioritized list of ORR activities becomes the basis for preparing DOE's national budget request. ORR competes nationally for funds based on highest priority needs nationally. DOE installations are prioritized nationally on an installationwide scale using rigorous and detailed guidelines. ER program managers and staff generally use their most highly prioritized activities as guides for scoring the entire installation.

The prioritization is also used when the fiscal year begins and funds are made available. Funds and work activity will be distributed according to concerns and needs reflected by the prioritization.

Once DOE-OR has received either the formal financial plan guidance or guidance on a continuing resolution for the start of the fiscal year in October, DOE-OR meets with the public, EPA, and TDEC to agree upon the precise number of activities to be accomplished for that fiscal year and the attendant schedules and deliverables. This negotiated scope of work is appended to the FFA/IAG and becomes the baseline against which the DOE FFA/LAG project manager reports each quarter to EPA and TDEC. 


\section{PROGRAM MANAGEMENT}

\subsection{ROLES AND RESPONSIBILITIES}

The ORR RAs will be conducted using a "lead agency" strategy to minimize duplication of effort and maximize oversight productivity. The lead agency is designated as the responsible agency for overseeing and coordinating the activities in accordance with the Agreement. The regulators will provide support within their oversight role to the lead agency.

\subsubsection{Lead Agency}

DOE-OR, as the lead agency for the ORR, provides the on-scene coordination to plan and implement response action under the NCP. Lead agency duties include:

- Overseeing and managing ORR remedial activities pursuant to the Agreement and the site management plan

- Serving as primary contact and coordinator with the regulators for the purposes of implementing the Agreement and the site management plan

- Ensuring availability of resources required to implement the site management plan

\subsection{Regulators}

EPA and TDEC are participating in the Agreement as both working partners in initiating the RA work at Oak Ridge and in a regulatory oversight role. In this capacity, they will provide regulatory opinions and counsel to the lead agency. The regulators will assist the lead agency by attending working meetings, providing timely response to action items, and providing timely review and concurrence, where applicable, of ORR remedial documentation and/or activities. EPA, DOE, and TDEC will each designate project managers to coordinate the implementation of the Agreement and the ongoing regulatory oversight duties and shall notify each other in writing of the designation.

\section{INTEGRATING CONTRACTOR}

The Energy Systems ER Division has been designated as integrating contractor for the DOE ER Program. The primary purpose of the integrating contractor role is to ensure that all participants in the Oak Ridge ER Program approach and conduct their tasks in a technically consistent and operationally similar manner to ensure a common focus for technical and administrative management. On the ORR, the primary contractors to DOE as of the date of this document are: Energy Systems; Radian Corporation; Ebasco Services, Inc.; and MK-Ferguson, in Oak Ridge. The specific ER Program responsibilities of each of these prime contractors are defined in the DOE ER Program Management Plan (DOE 1991b) and the DOE D\&D Program Management Plan (DOE 1991a).

In fulfilling its role as integrating contractor, Energy Systems will be the focal point each year for coordinating the preparation of the ADSs, contributions to the five-year planning effort, the installation-specific plans, budget, schedules, and budget packages for the 
prioritization process. In this integrating contractor role, the Energy Systems ER Division will conduct meetings, collect information, and assemble total packages related to these activities for use by DOE-OR. The ER Division will ensure that technical consistency is achieved among the participants in areas such as risk assessment, NEPA compliance, and WM for ER activities, among others. The Energy Systems ER Division will have primary responsibility for reporting total ER Program cost and schedule status each month. The Energy Systems ER Division will obtain budget, cost, schedule, and progress information from the technical support contractor (Radian Corporation), the RD contractor (Ebasco Services, Inc.), the construction manager, and DOE-OR each month and consolidate this information in the monthly status report to be submitted to the Director of the DOE-OR ER Division.

The Energy Systems ER Division also has the following responsibilities as integrating contractor:

- Evaluate other DOE prime contractor, subcontractor, and prospective subcontractor ER programs, procedures, systems, processes, and policies regarding health and safety, housekeeping, environmental requirements, radiation protection, security, QA, and related operations.

- Provide coordination with plant operations with respect to any field work, including RIs and RAs.

- Evaluate design, strategies, and sequencing of work in accordance with existing project management procedures, established by the assistant manager for construction and engineering, with respect to the RD architect-engineer.

- Participate in and chair the Level IV Change/Configuration Control Board. The Energy Systems ER Division will process and maintain all change requests and approvals for DOE-OR ER Program projects.

- Prepare ER Program technical and administrative policy and procedures for use by ER Program participants.

- Coordinate technical reviews of all products, plans, schedules, and documents prepared by all ER Program participants in fulfillment of regulatory deliverables to ensure consistency of technical approach, adequacy, and completeness of the assessments, and to ensure that regulatory requirements are being met.

- Provide WM TSD services for management of ER-originated wastes in a manner consistent with regulatory guidance.

- Conduct a rigorous self-assessment program to evaluate regulatory compliance and procedure adherence during the conduct of ER activities.

- Develop and operate OREIS, a system used to manage all environmental data products on the ORR.

- Coordinate and evaluate pricrities for DOE-OR ER Program ongoing and proposed activities to ensure that the highest priority remediation projects are funded and pursued commensurate with DOE funding availability balanced against public/community 
concerns, regulatory requirements, human health and environmental risk assessments, and institutional considerations.

\subsection{WORKING SESSIONS AND RA PROGRAM MEETINGS}

\subsubsection{Working Sessions}

Several times during the RI, decision, and cleanup activities at an OU, working meetings will be held with EPA, TDEC, DOE staff, OU project managers, and OU project teams. At these meetings, all agreements and assigned action items will be documented and signed before concluding the meeting. These signed documents will be taken to the main offices of the Parties for review and concurrence by the FFA/IAG program managers. If there is any disagreement with any of the agreements and/or action items that cannot be quickly resolved by the program managers, these issues will be taken up at the next program managers meeting or the RA Program meetings. The agreements and action items that affect the scope of the OU work will not be acted on until the documents have been approved by the FFA/AG program managers.

\subsubsection{RA Program Meetings}

The RA Program meetings are held once each quarter with the staff of the Parties to exchange information on the state of the program (i.e., action item status and FFA/AG document review status) and to obtain information on issues that transcend the work at the reservation (i.e., groundwater program, risk assessment, consolidated environmental data base, etc.). The format of this meeting is not usually OU-specific unless it has been determined that the knowledge would be veneficial to all. 


\section{REFERENCES}

DOE 1990. Summary of the Final National Contingency Plan and an Analysis of the Implications for DOE. Report EH-231. DOE Office of Environmental Guidance, RCRA/CERCLA Division. Page 25. August 1990.

DOE 1991a. Management Plan for the DOE Field Office, Oak Ridge Decontamination and Decommissioning Program. Report DOE/OR-975, Rev. 0 (draft issued for approval). Prepared by Martin Marietta Energy Systems, August 1991.

DOE 1991b. Management Plan for the Oak Ridge Operations Environmental Restoration Program. Report DOE/ORO-931, Rev. 0. Prepared by Martin Marietta Energy Systems, March 1991.

EPA 1990. Proposed Federal Facility Agreement for the Oak Ridge Reservation. Environmental Protection Agency. December 1990.

Kimbrough, C. W. et al. 1988. Environmental Surveillance Procedures QC Program. ESH/Sub/87-21706/1. Prepared for Martin Marietta Energy Systems, Oak Ridge Natl. Lab., Oak Ridge, Tenn.

PEER Consultants, P.C. 1991. Community Relations Plan for the Environmental Restoration Program at the Oak Ridge Reservation, Oak Ridge, Tennessee. Report DOE/ORO 928 (ES/ER-5, ES/ER/Sub-89/H0908/1). Prepared for Martin Marietta Energy Systems. Oak Ridge, Tenn.

Sleeman, R. C., Director, DOE Environmental Restoration Division, April 4, 1991. Letter to Lanny D. Bates, Energy Systems ER Division Director. Subject: "Policy and Procedures for Environmental Restoration (ER) Program's Risk Assessment." 
Appendix A

RCRA/CERCLA SCHEDULE LOGIC 


\section{RCRA/CERCLA Schedule Logic}

After submittal of a Resource Conservation and Recovery Act (RCRA) postclosure permit application to the Tennessee Department of Environment and Conservation (TDEC), the following schedule process shall occur.

1. RCRA facility investigation/remedial investigation (RFI/RI) work plans shall be submitted and approved by TDEC and the Environmental Protection Agency (EPA) regional offices.

2. RFI/RI implementation shall proceed immediately upon approval by TDEC and EPA.

3. RFI/RI reports shall be completed and submitted to TDEC and EPA in accordance with the Federal Facility Agreement/Interagency Agreement (the Agreement) among the Parties.

4. Feasibility study/corrective measures study/environmental assessment (FS/CMS/EA) reports shall be completed and submitted in accordance with the requirements and schedules of the Agreement.

5. The Department of Energy (DOE) shall submit the proposed remedial action plan/corrective measures plan to TDEC and EPA for review and approval.

6. The draft postclosure permit application shall be revised to incorporate the remedial action/corrective measures plan cleanup criteria.

7. Both the draft postclosure permit and the proposed remedial action/corrective measures plan shall be issued for public notice simultaneously.

8. The final postclosure permit shall be issued and the interim Record of Decision or the Record of Decision signed.

In the event that the RFI/RI FS/CMS/EA process is not complete prior to TDEC's issuing the final RCRA postclosure permit, DOE shall request an exception to the administrative requirements to consolidate remedial actions and avoid redundant activities by meeting Comprehensive Environmental Response, Compensation, and Liability Act standards and timetables. 
Appendix B

NO FURTHER ACTION DETERMINATION 


\section{No Further Action Determination}

The U.S. Department of Energy, the U.S. Environmental Protection Agency-Region IV, and the state of Tennessee have completed a review of the referenced information for as it pertains to the Oak Ridge Reservation Federal Facility Agreement. Based on this review, the Parties have determined that no further action for purposes of investigation or study is justified. This decision is subject to review at the time of issuance of the Record of Decision.

Brief summary of the basis for no further action:

References:

DOE Project Manager

Date

EPA Project Manager

Date

Tennessee Project Manager

Date

B-3 
Appendix C OPERABLE UNIT LIFE-CYCLE SCHEDULES 
C-3

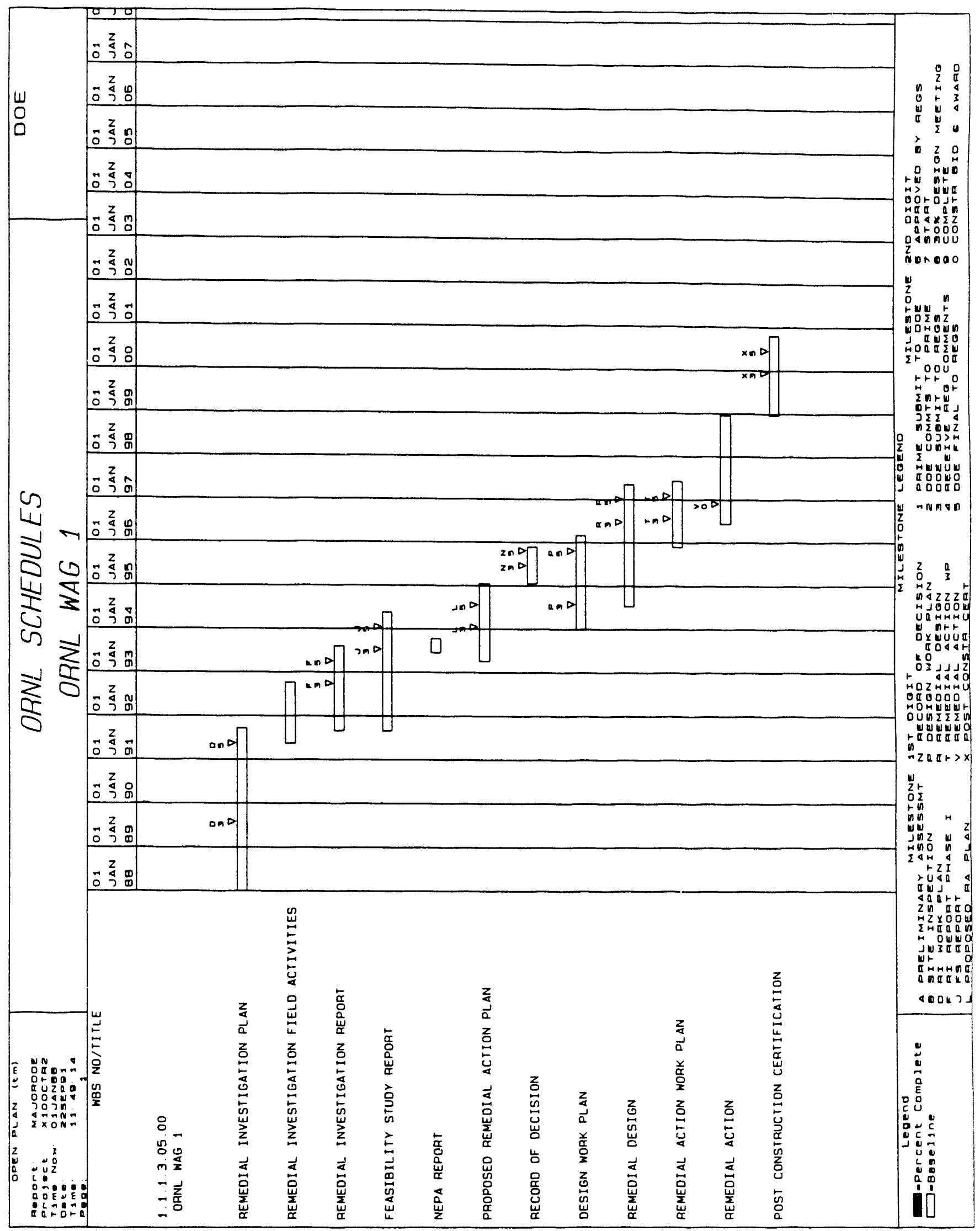




\section{C-4}

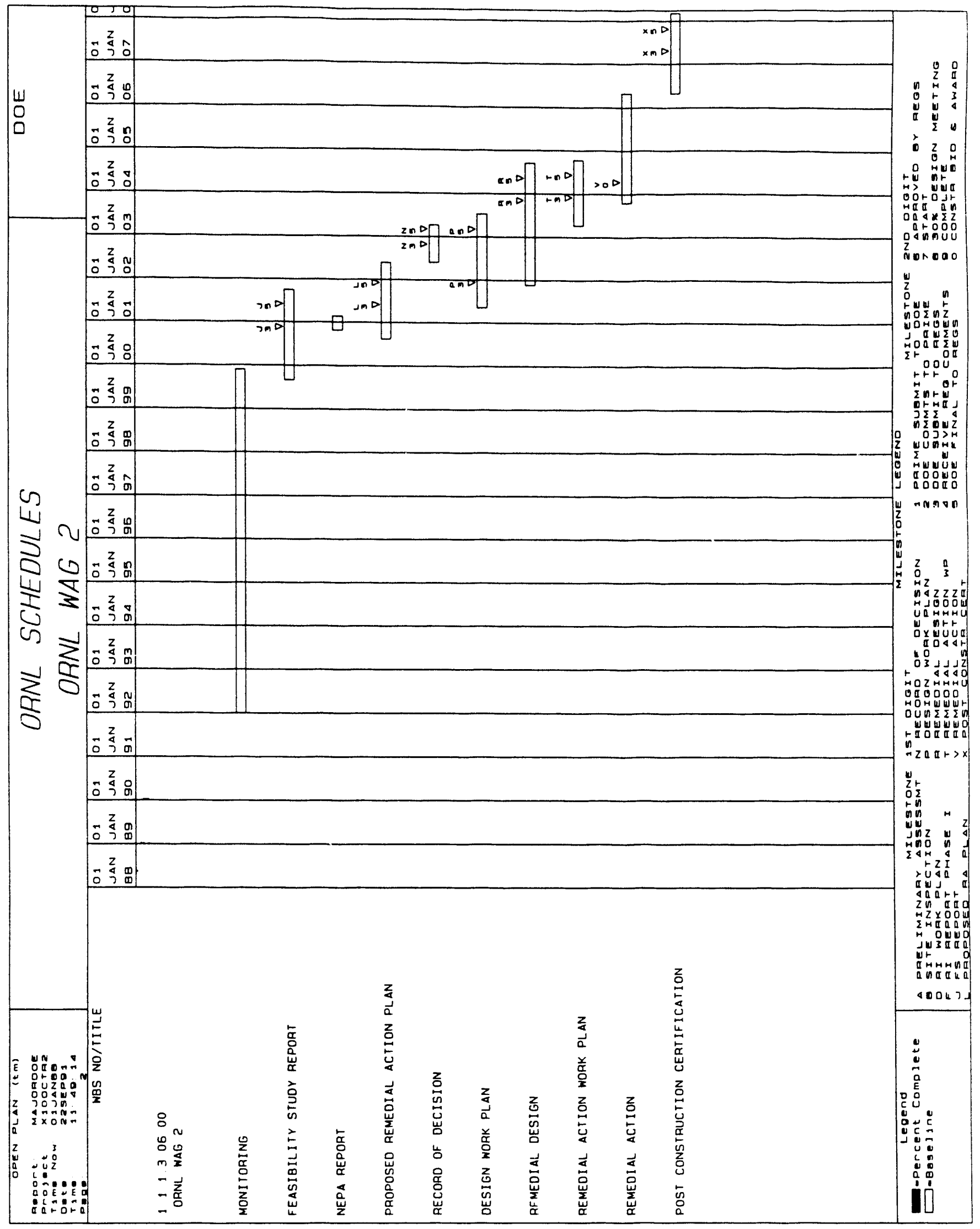


C-5

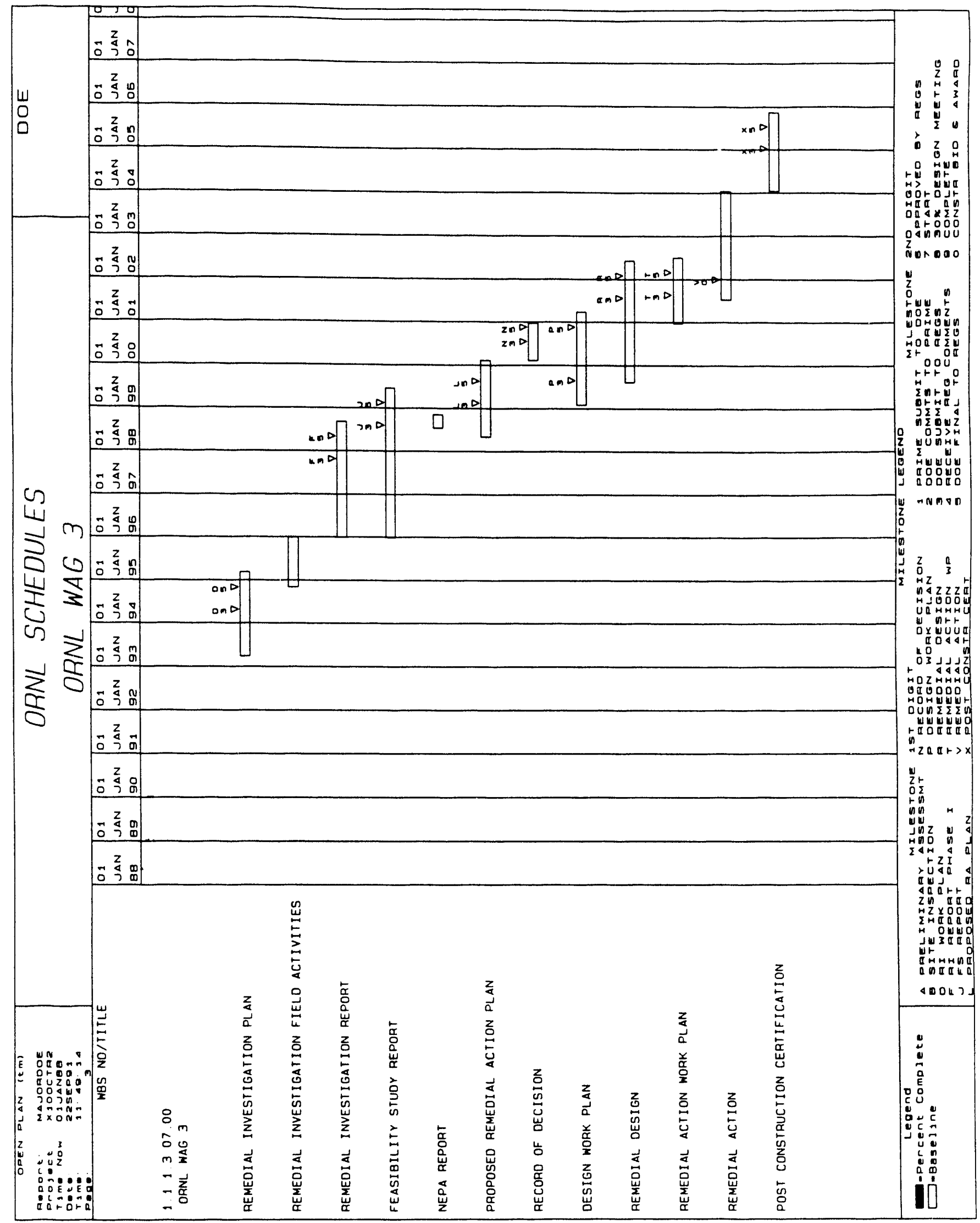


C-6

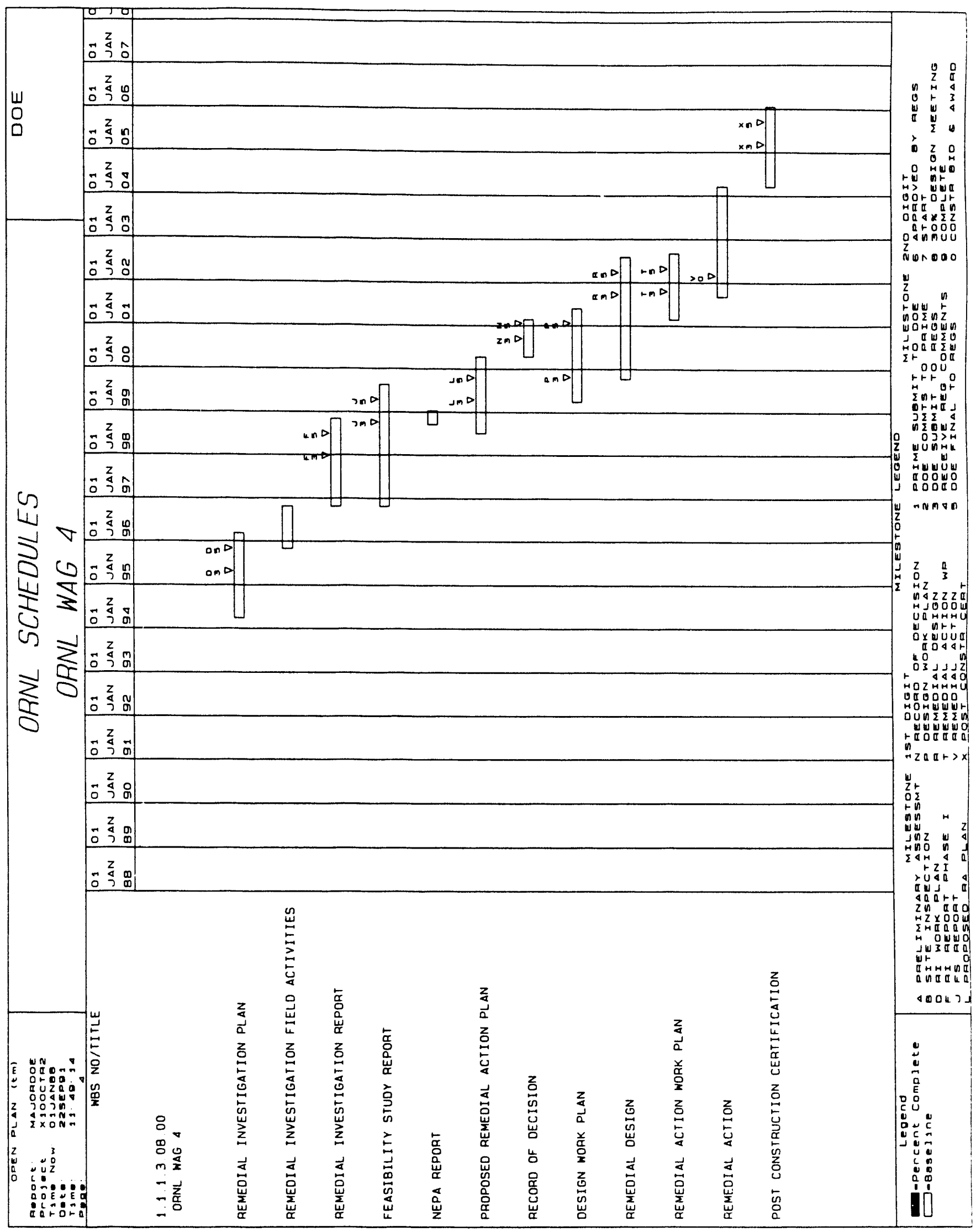


C-7

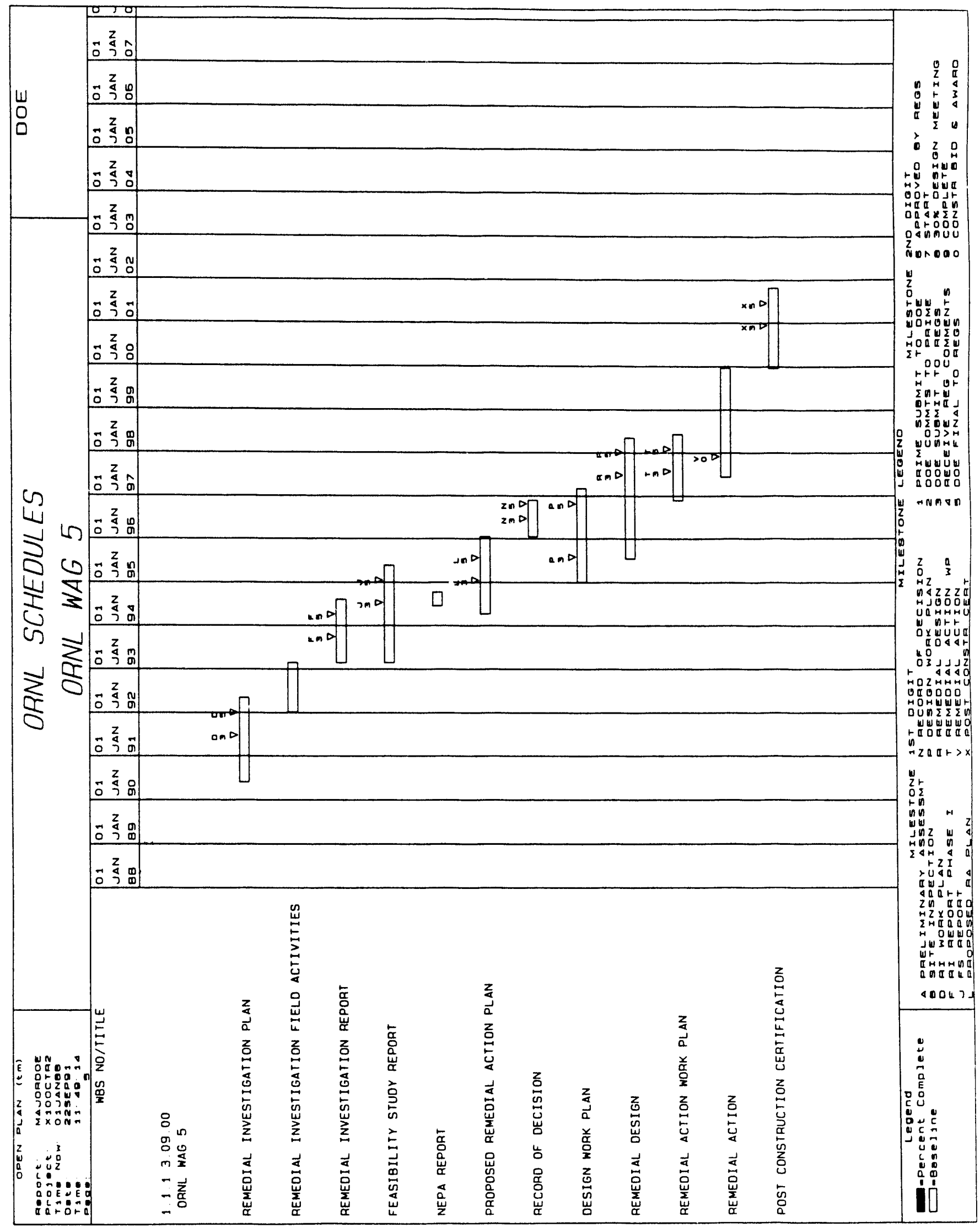




\section{C-8}

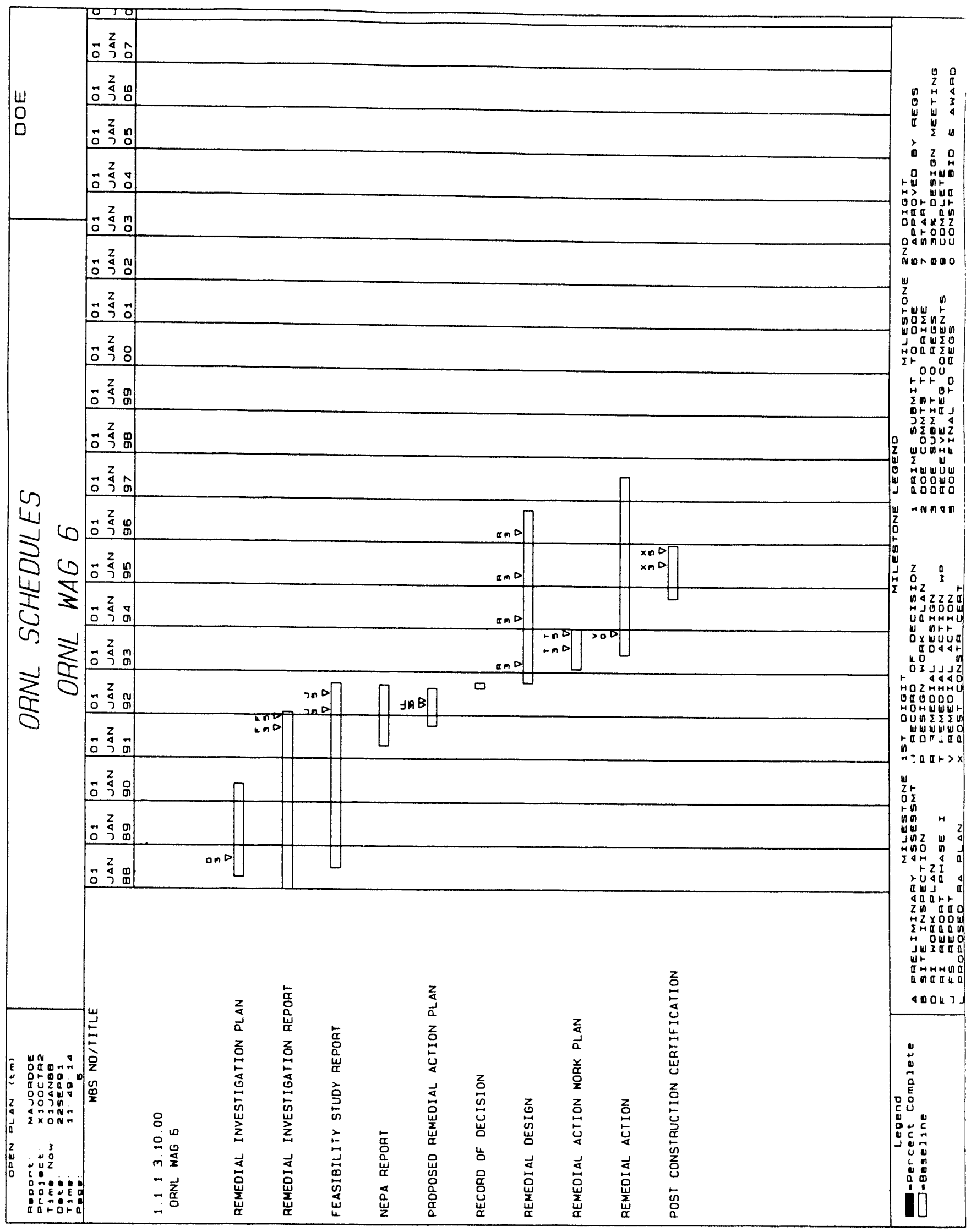




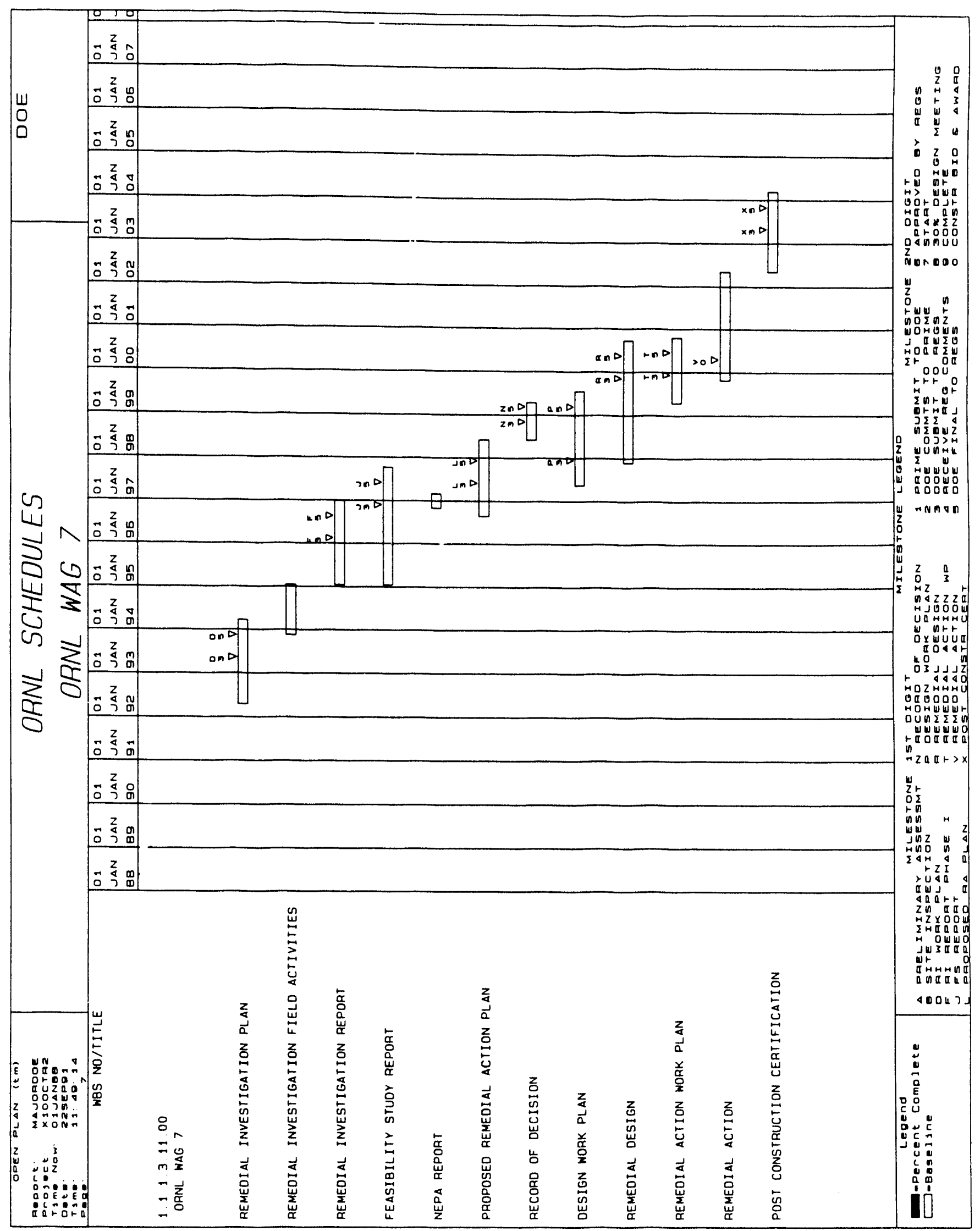




\section{C-10}

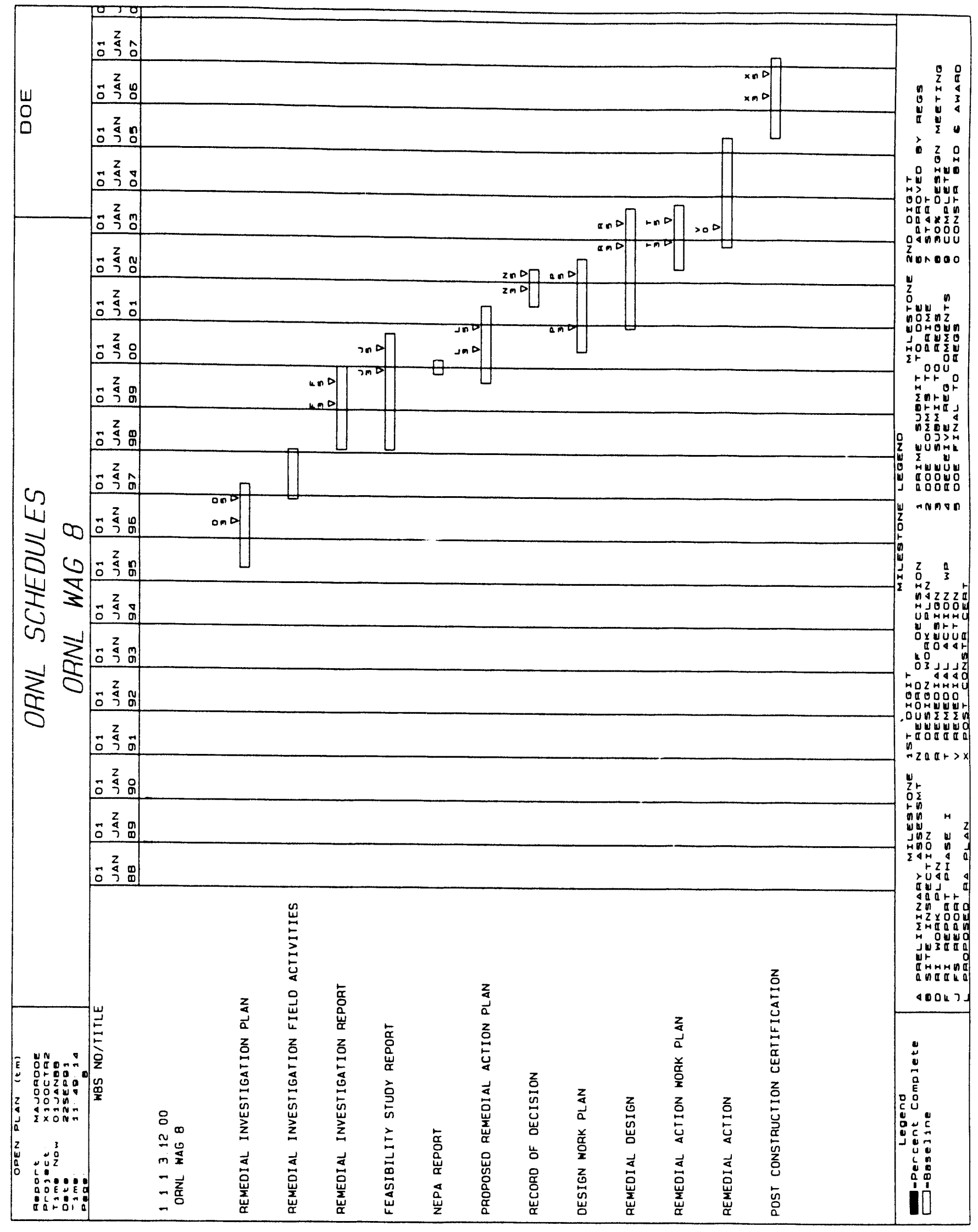




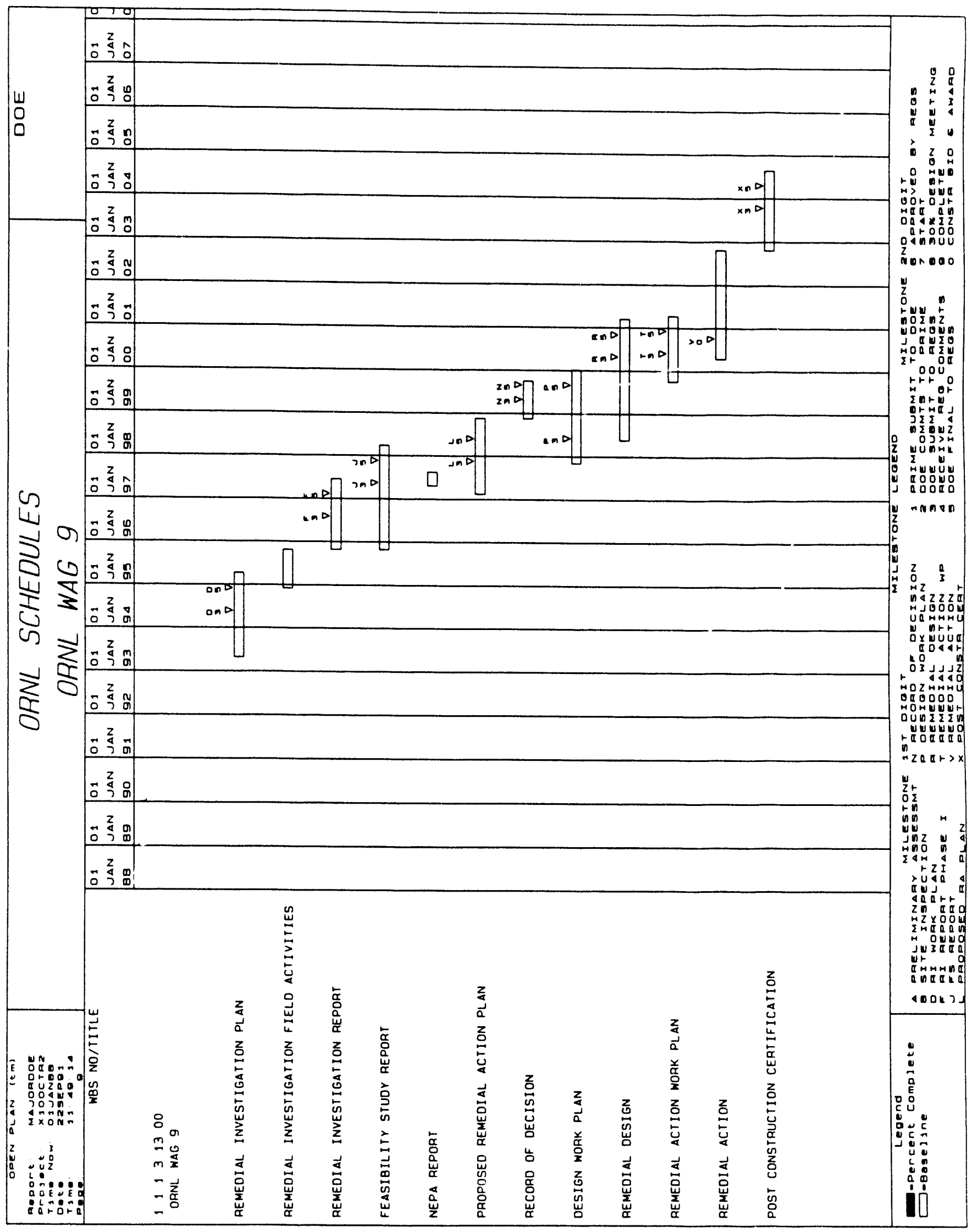


C-12

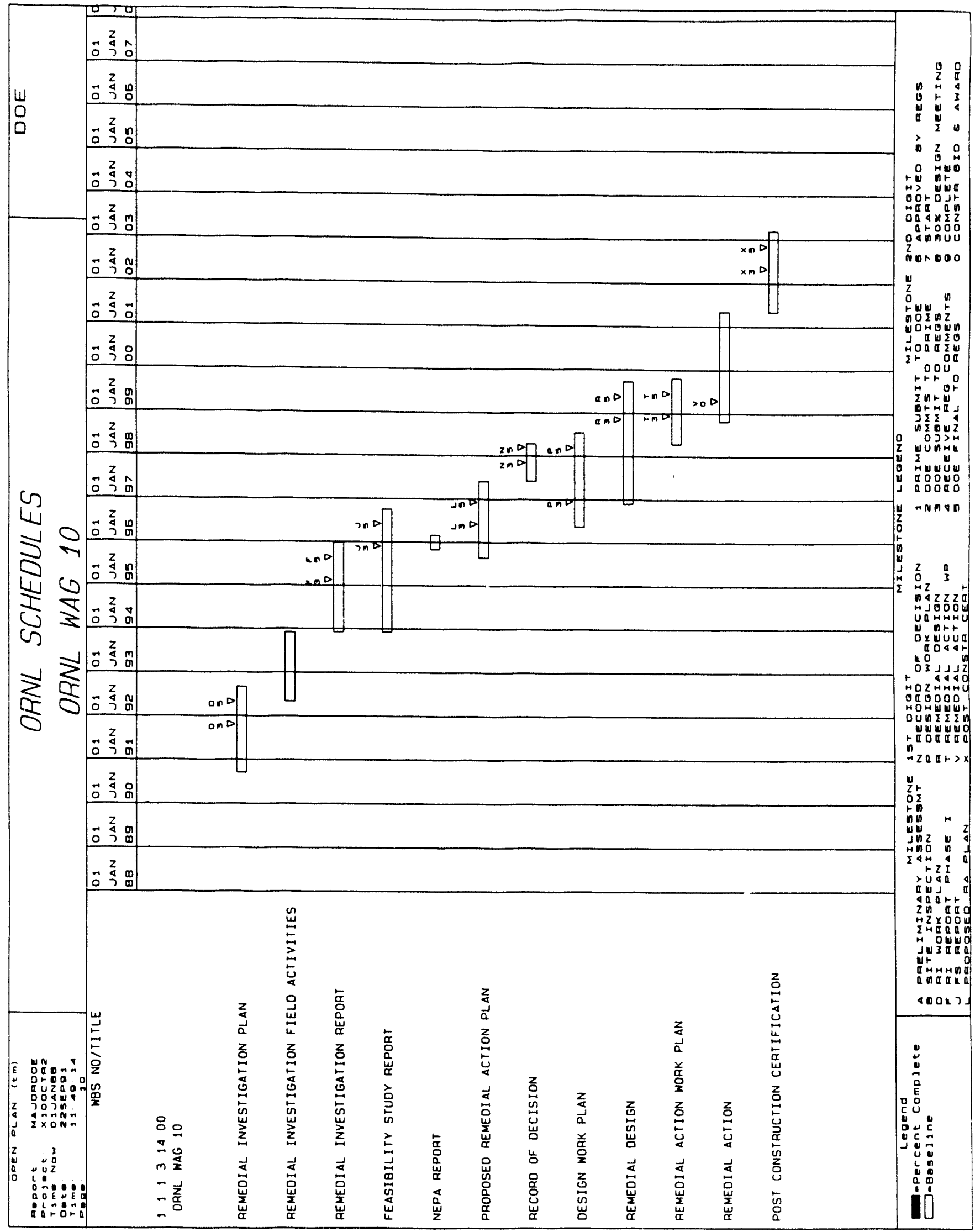




\section{C-13}

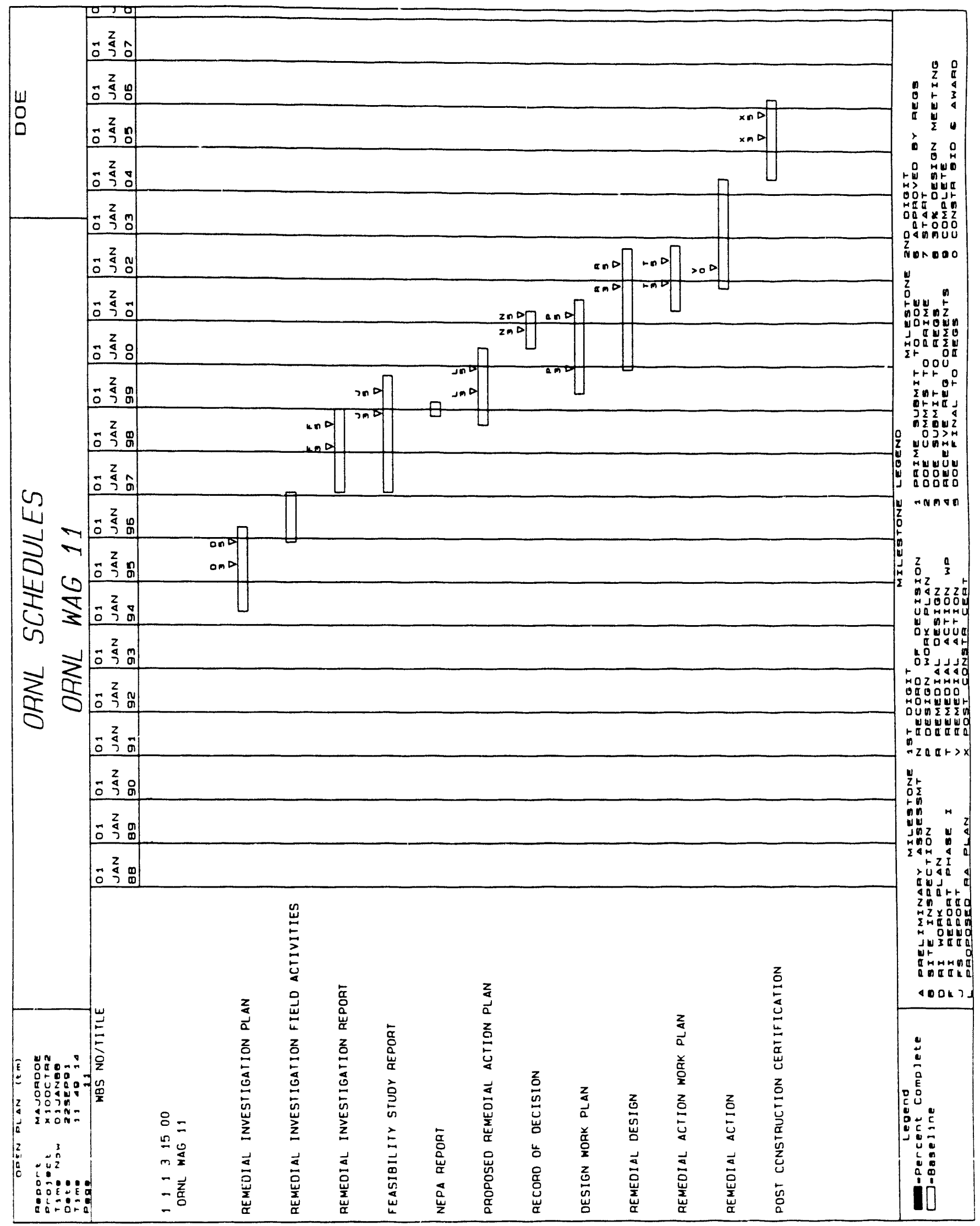




\section{C-14}

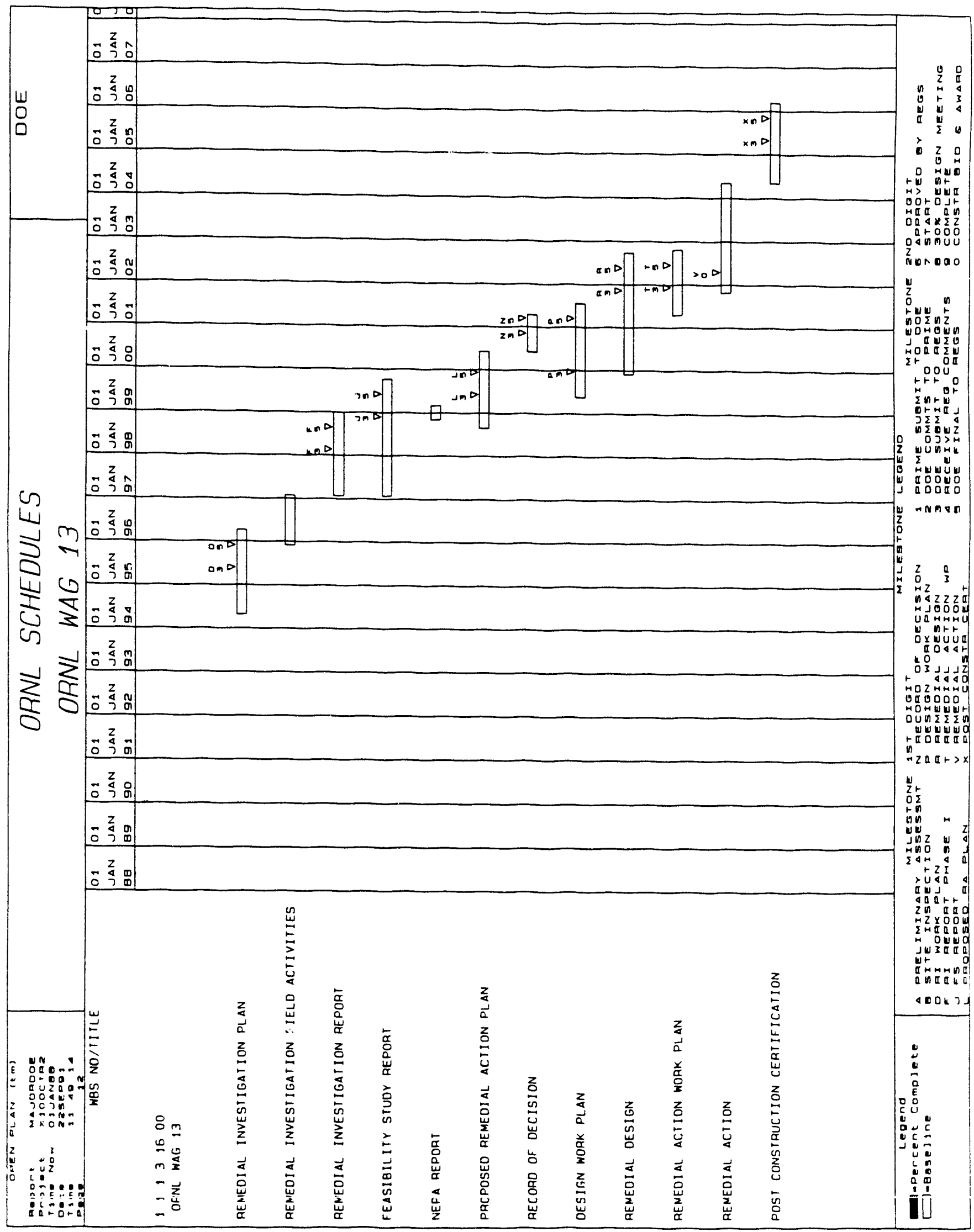


C-15

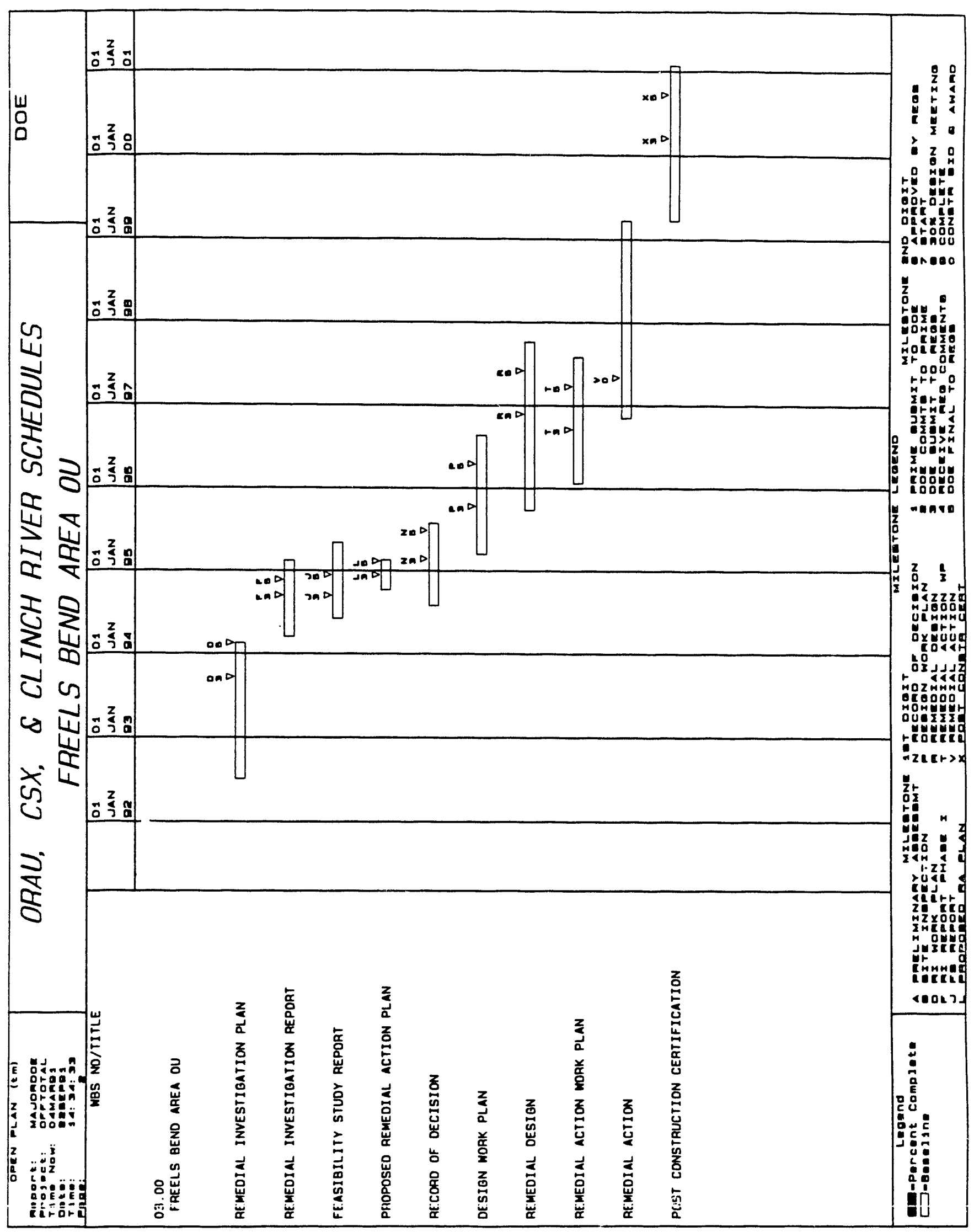


C-16

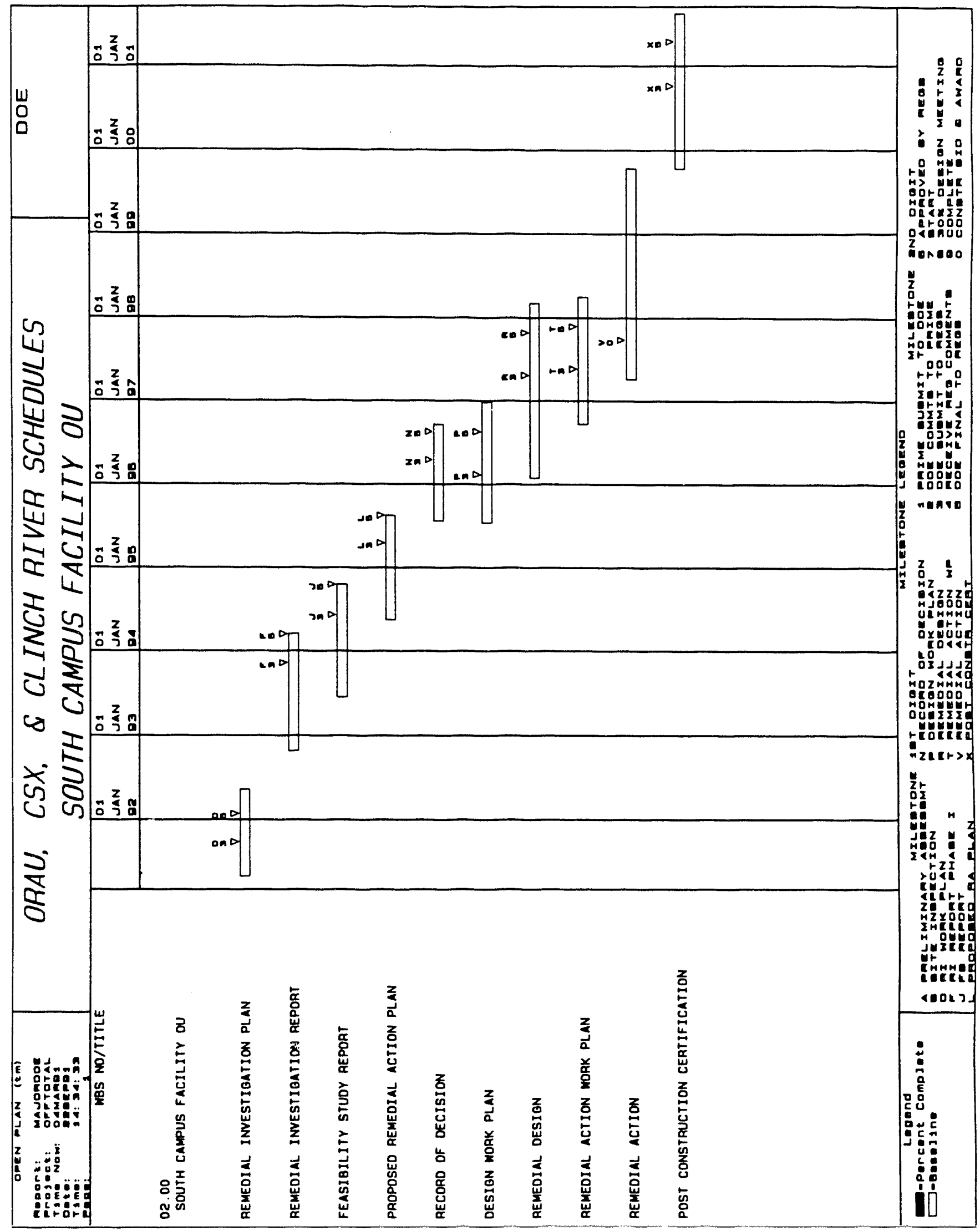


C-17

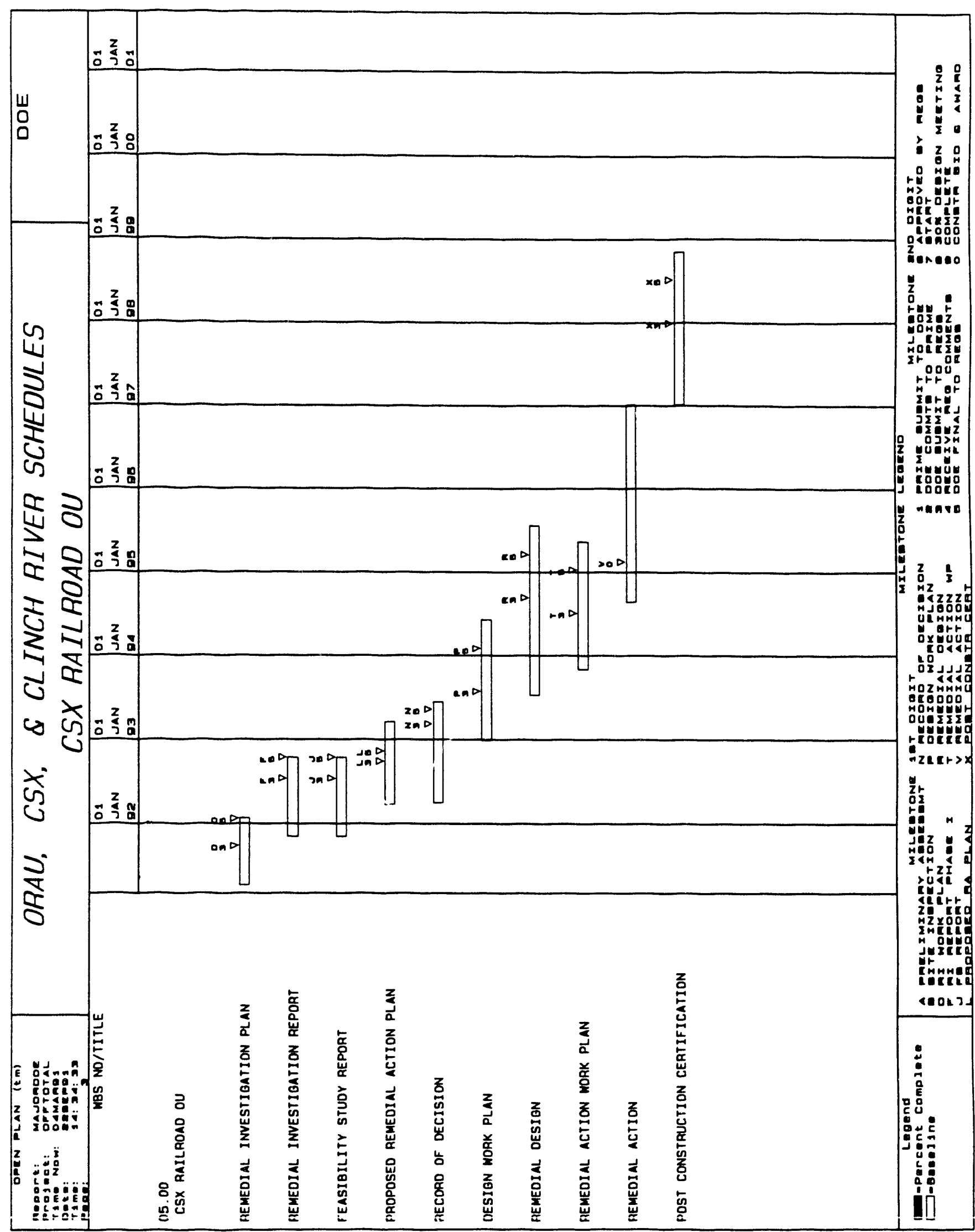




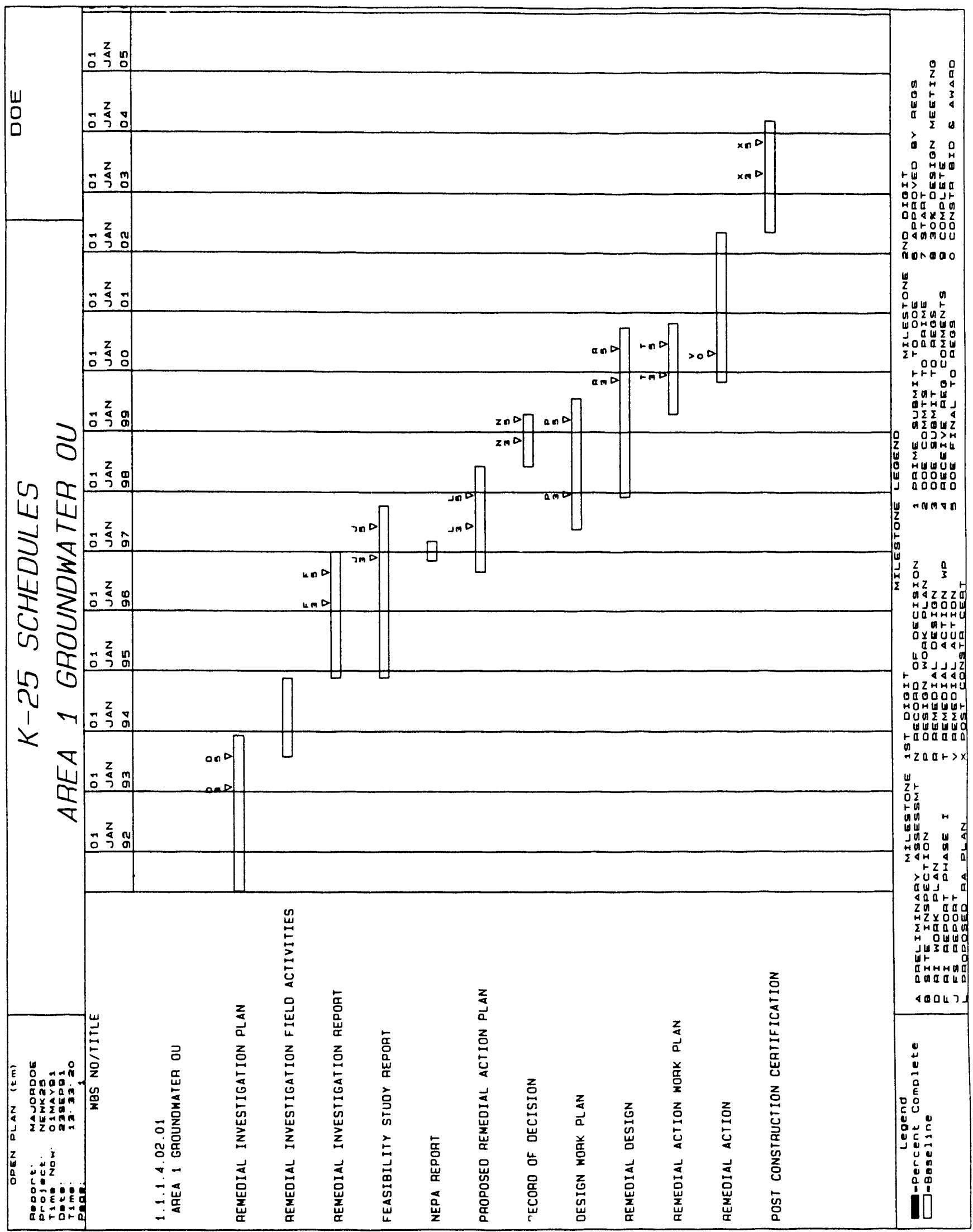




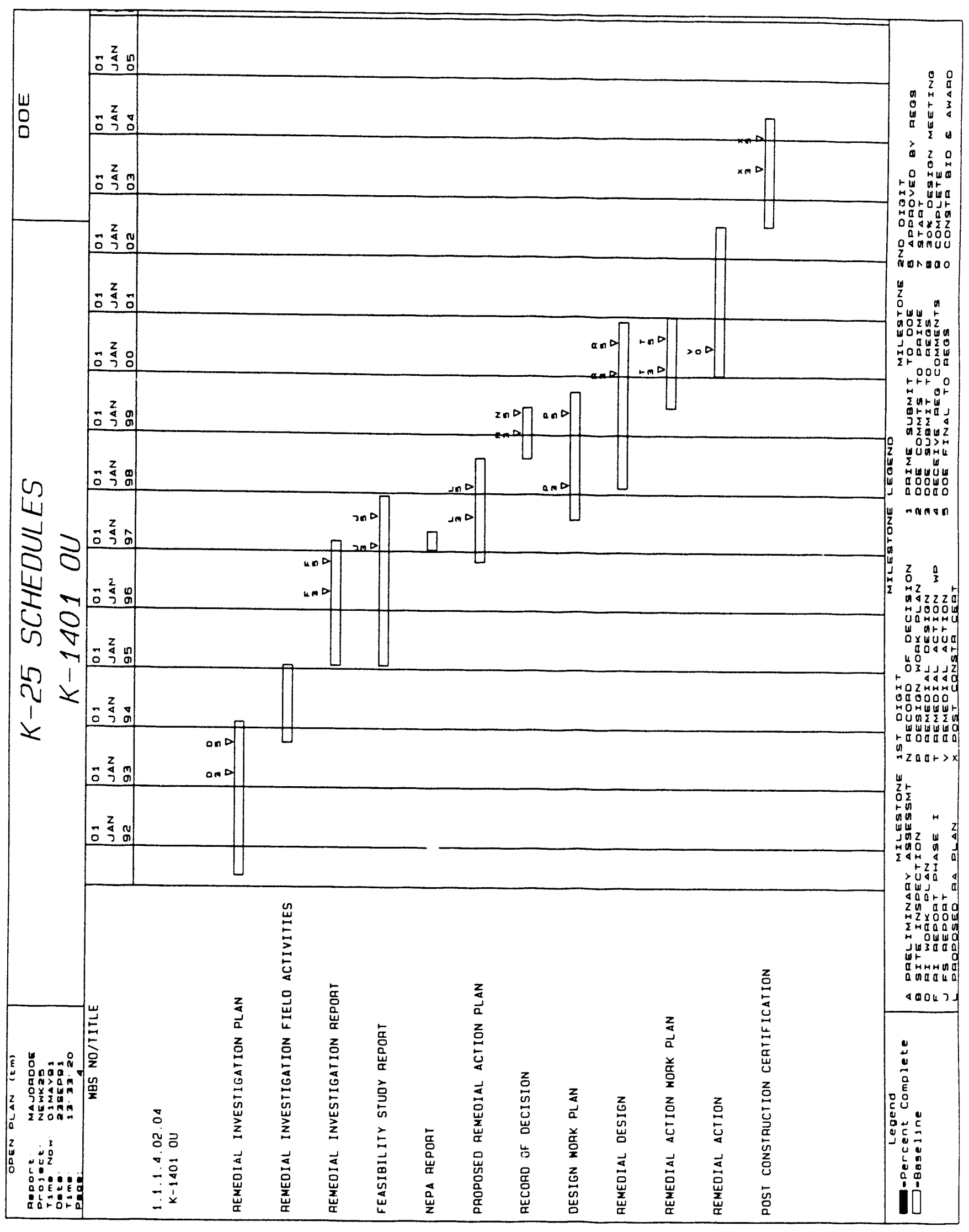




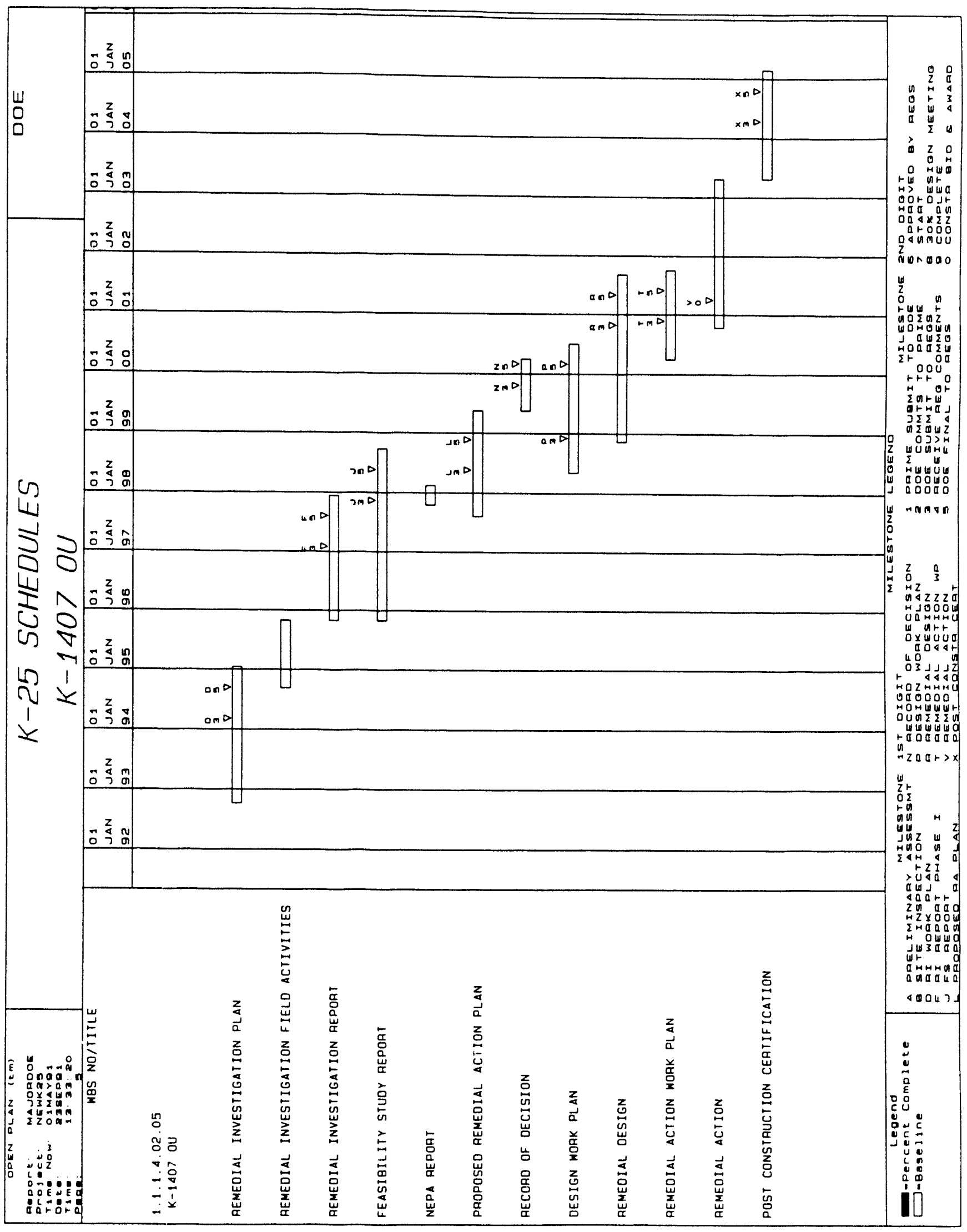




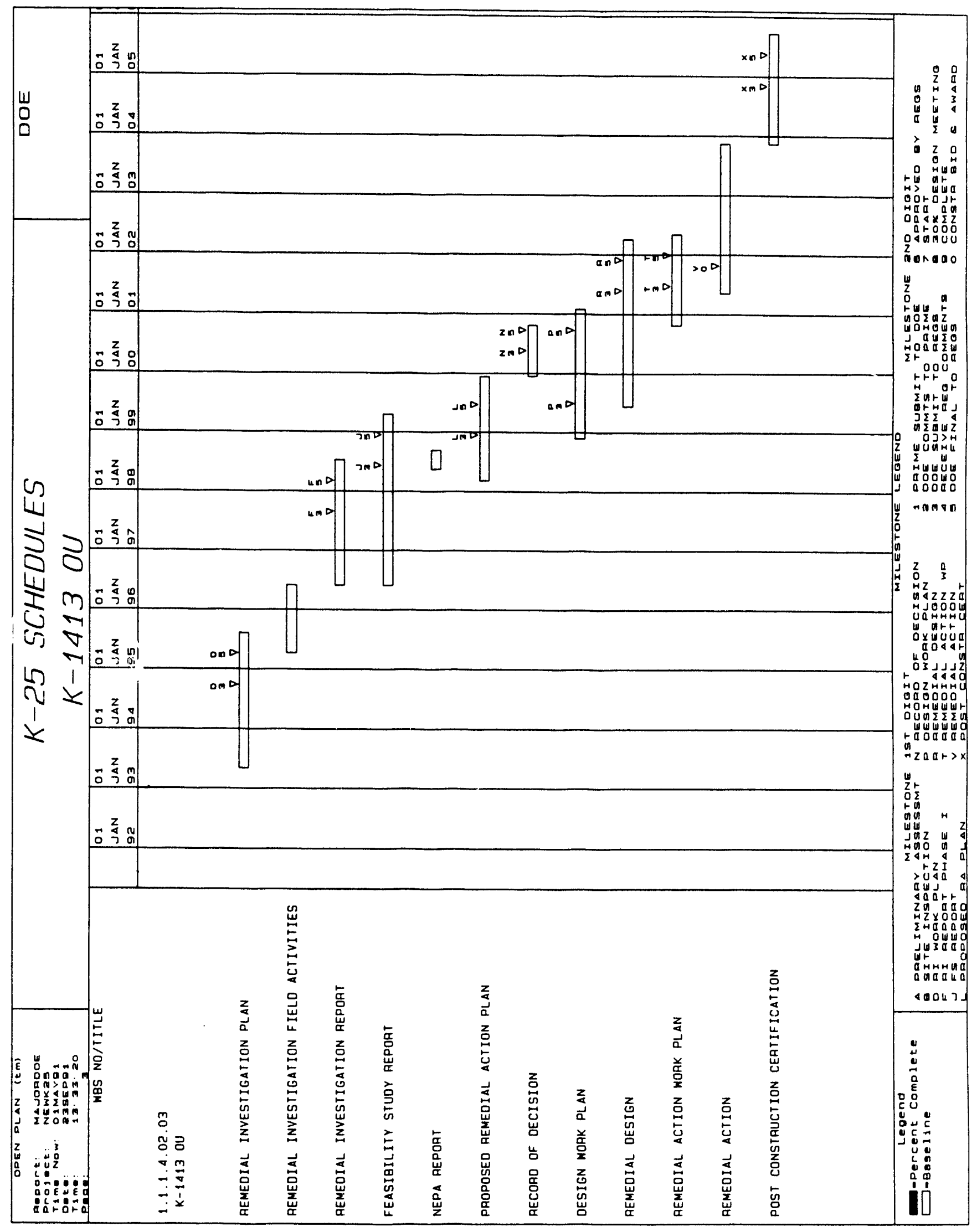




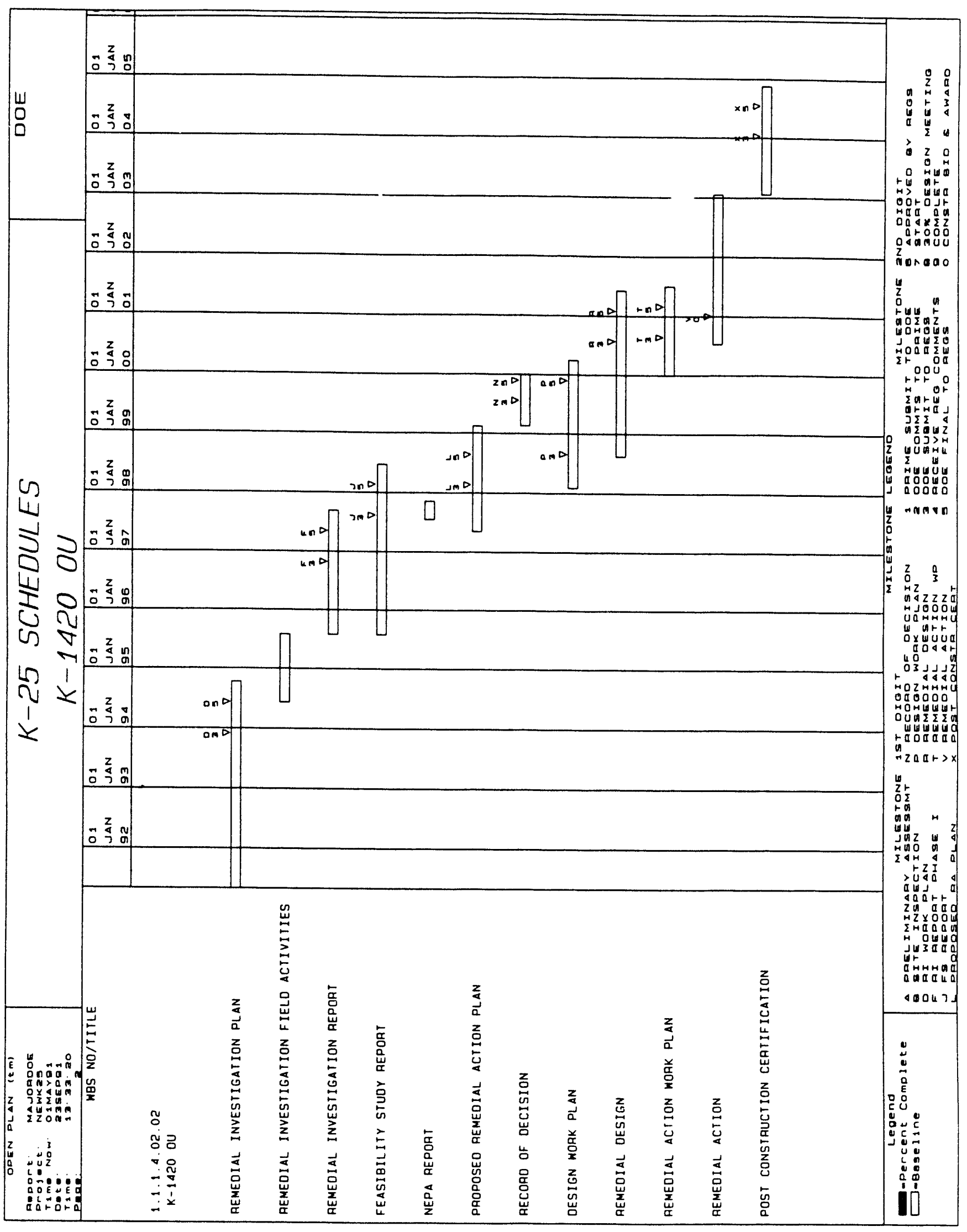




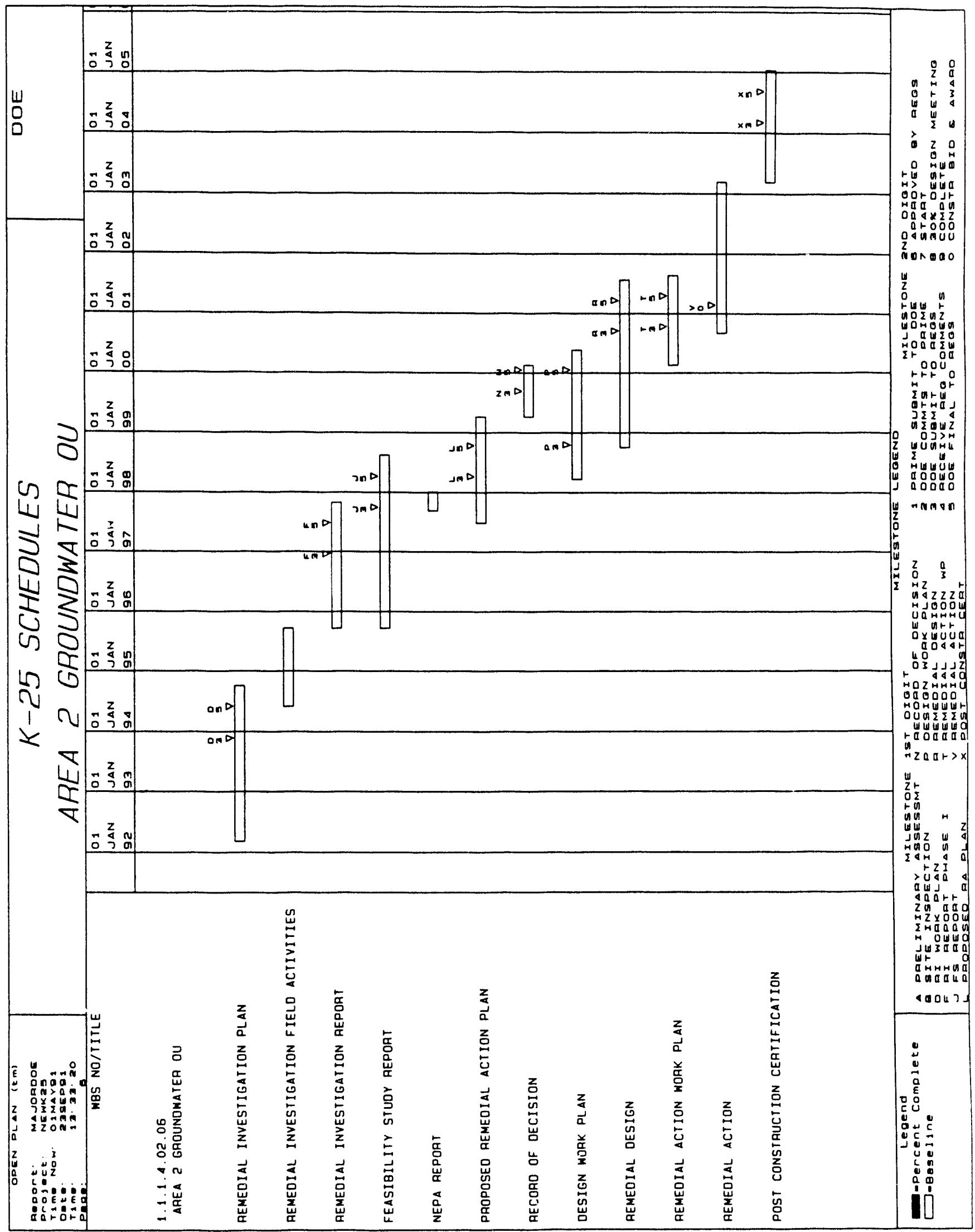




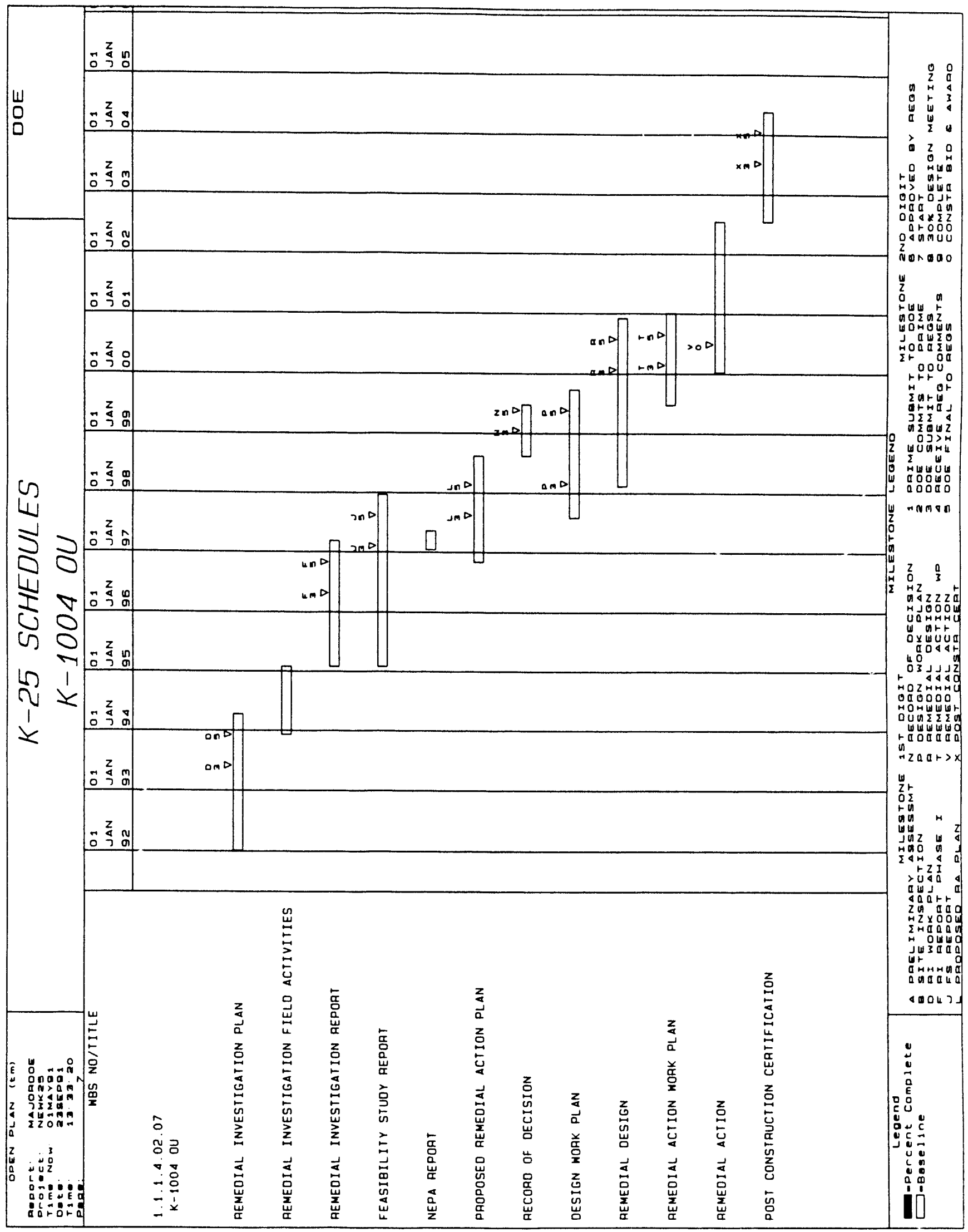


C-25

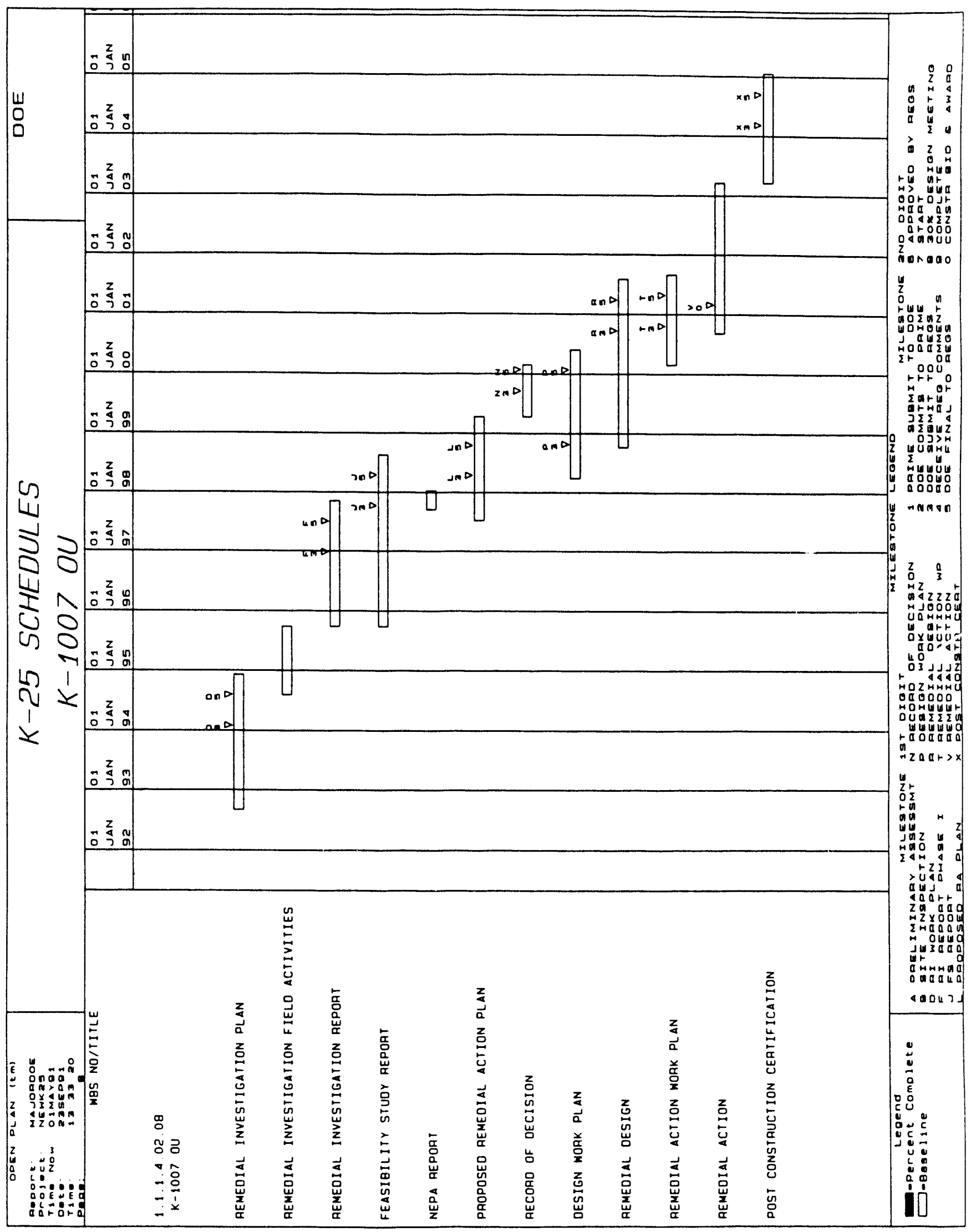




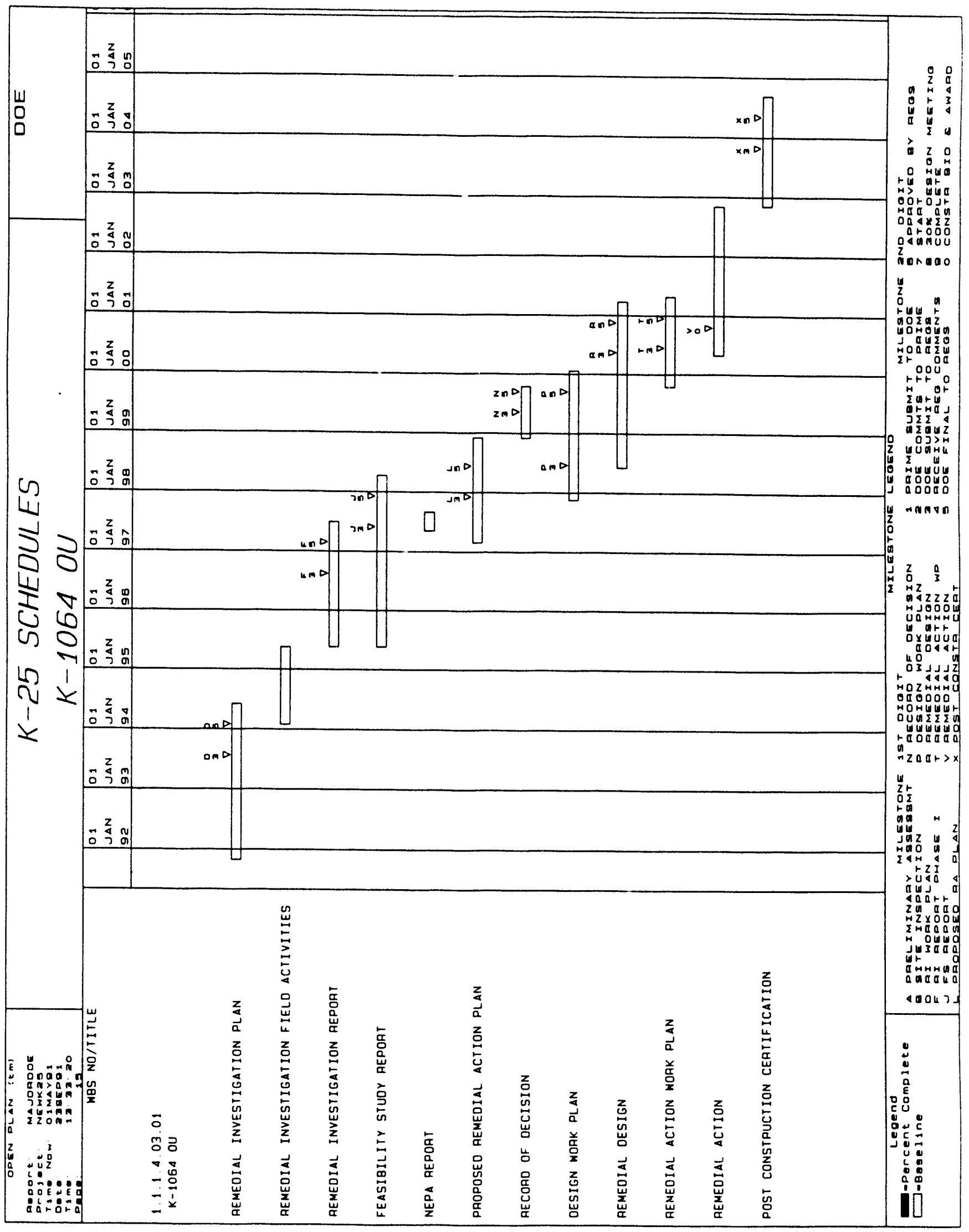




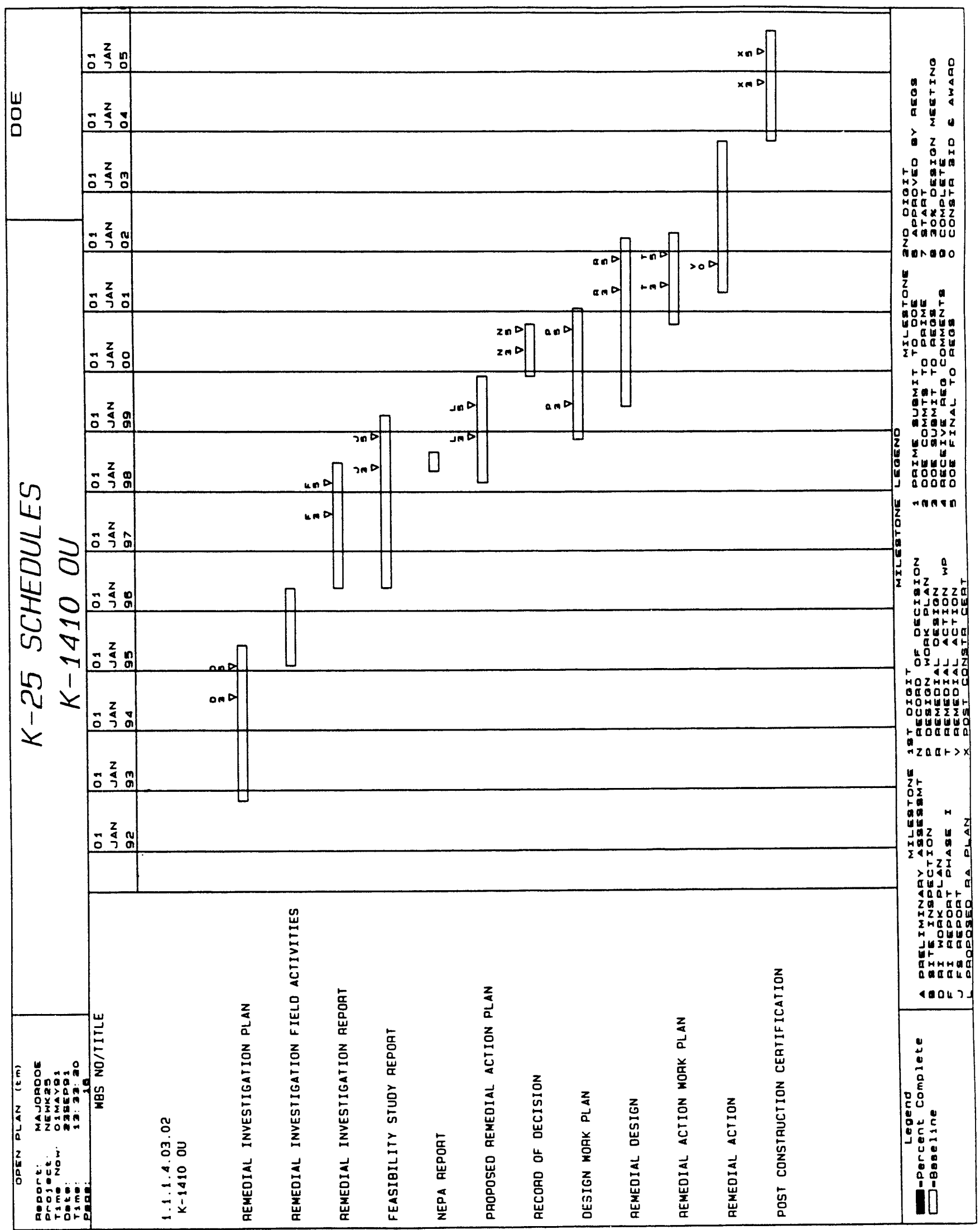




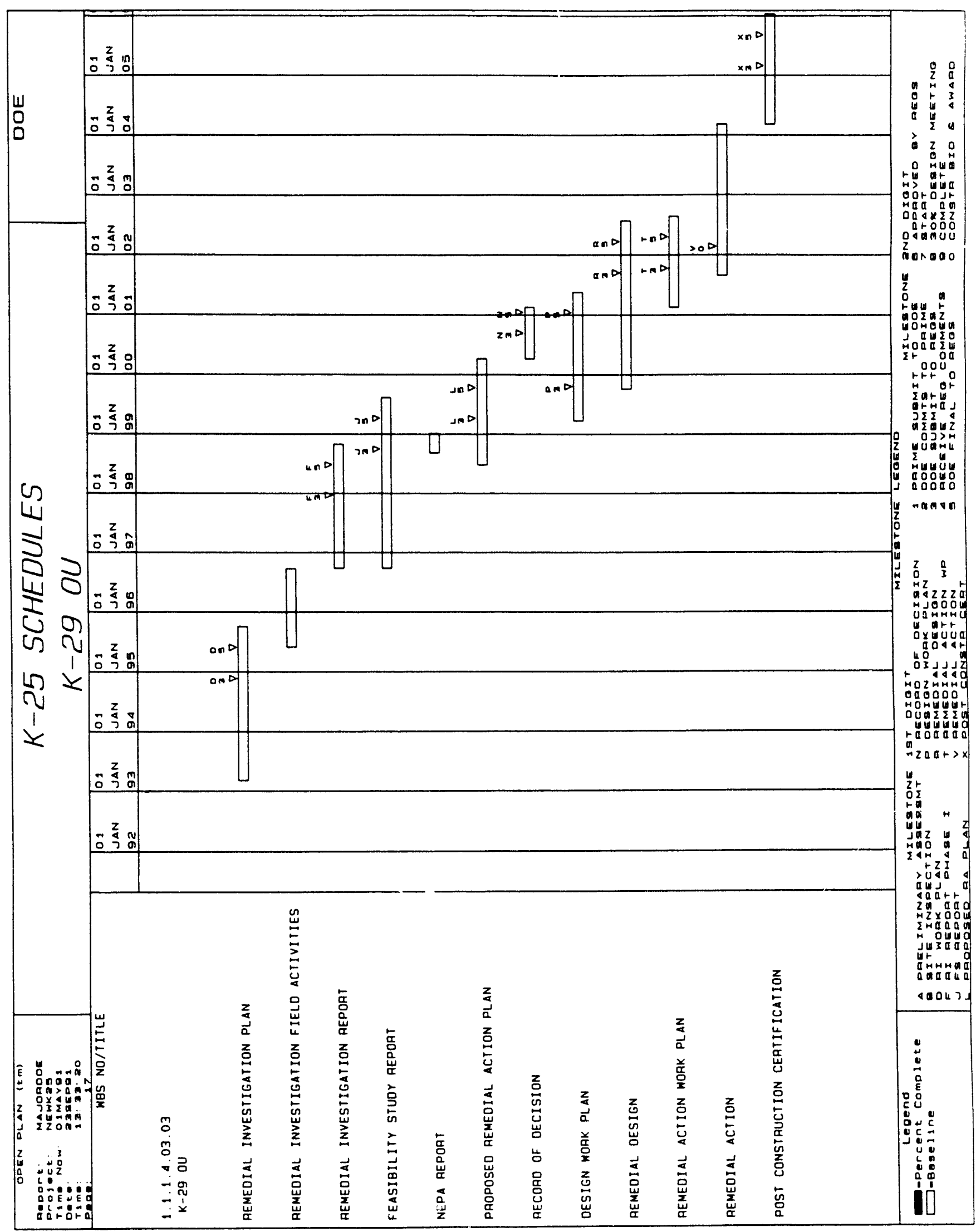




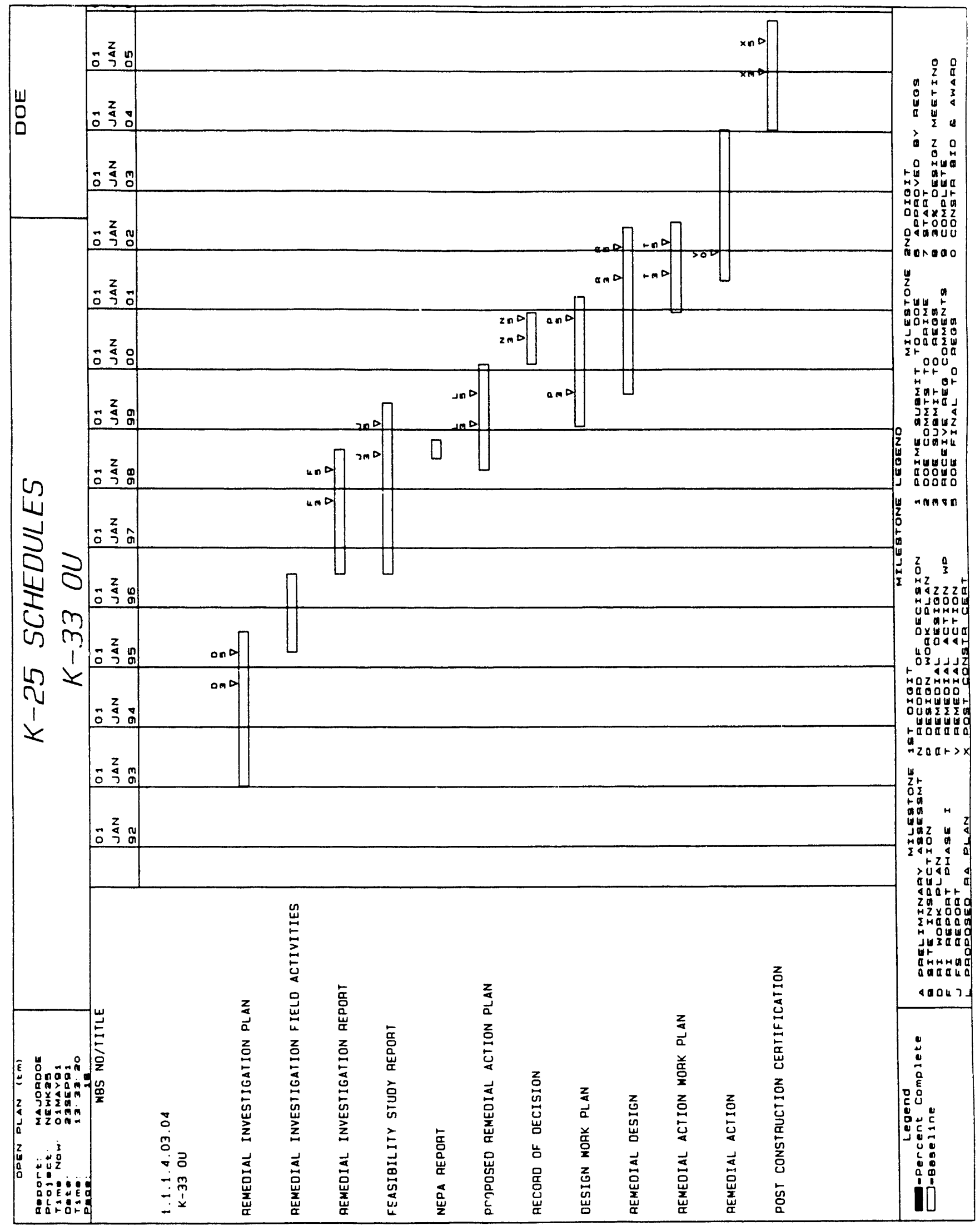


C-30

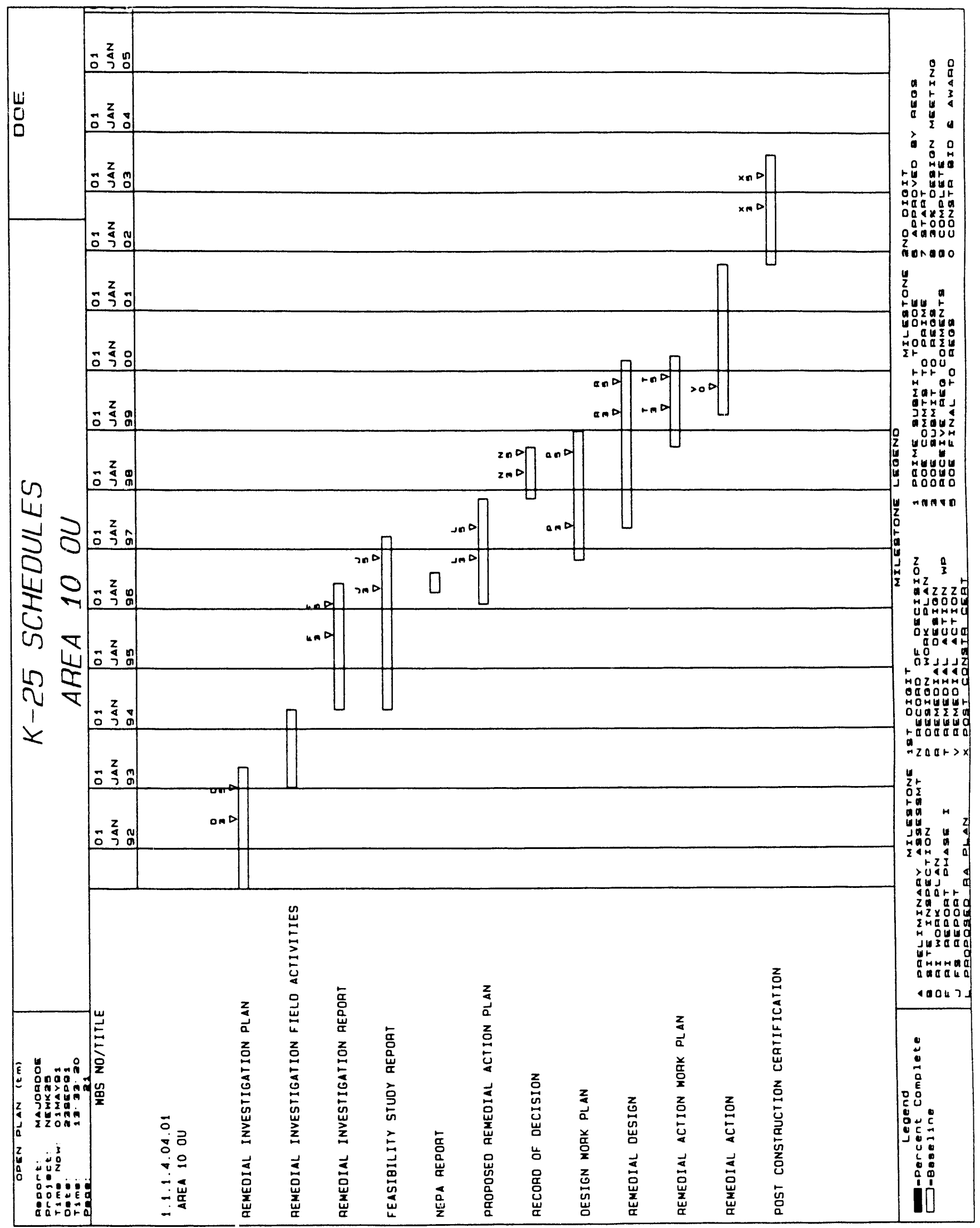




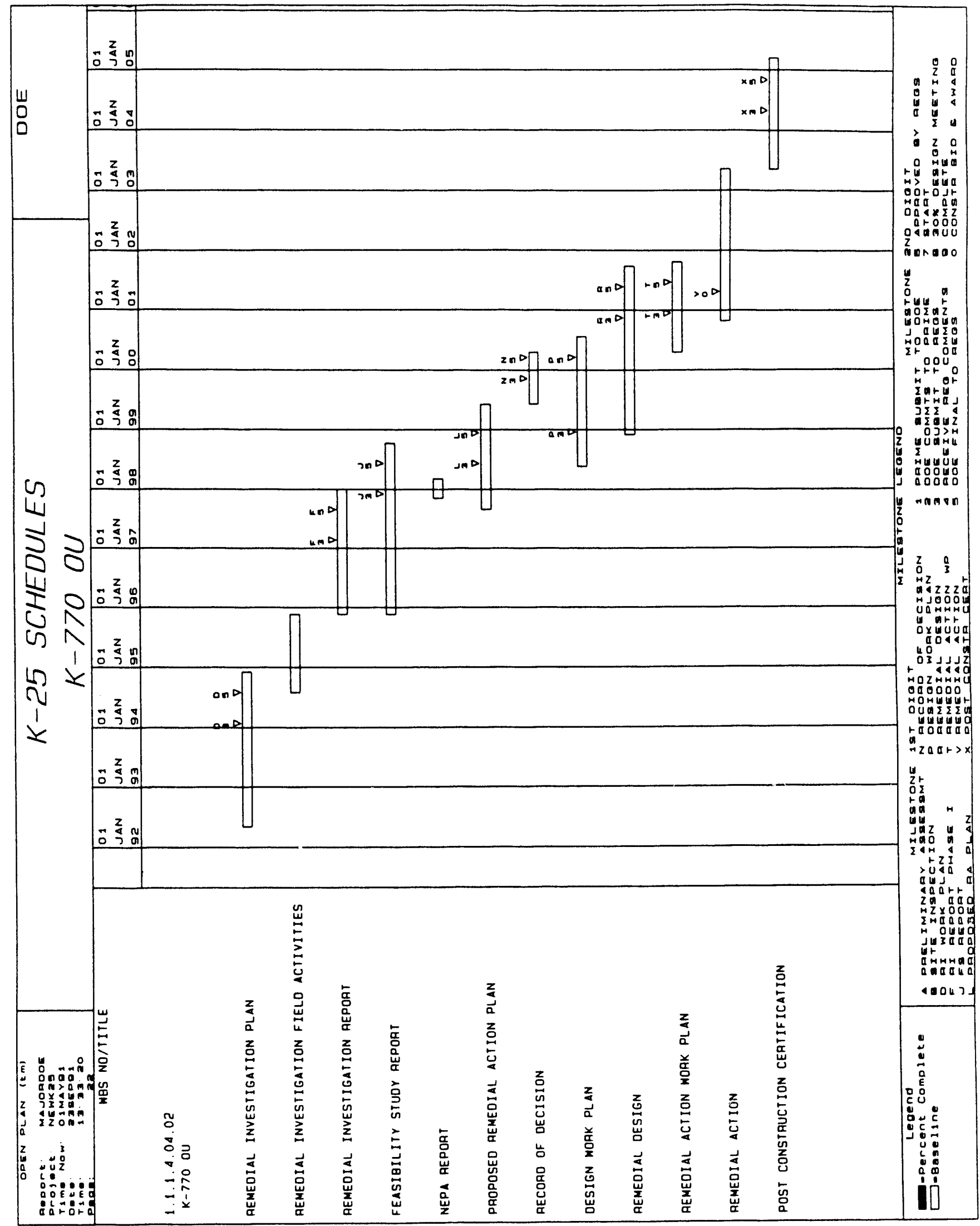




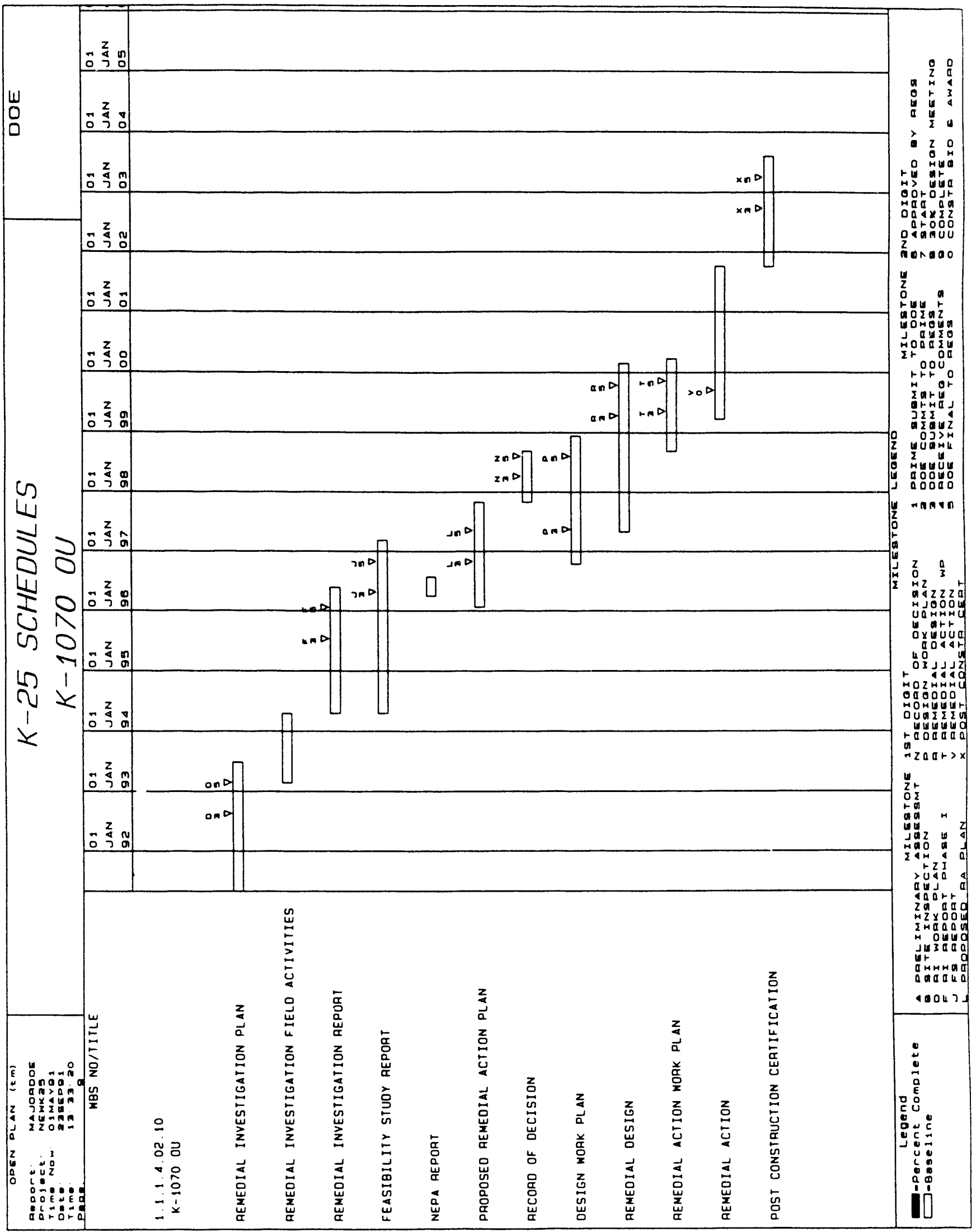




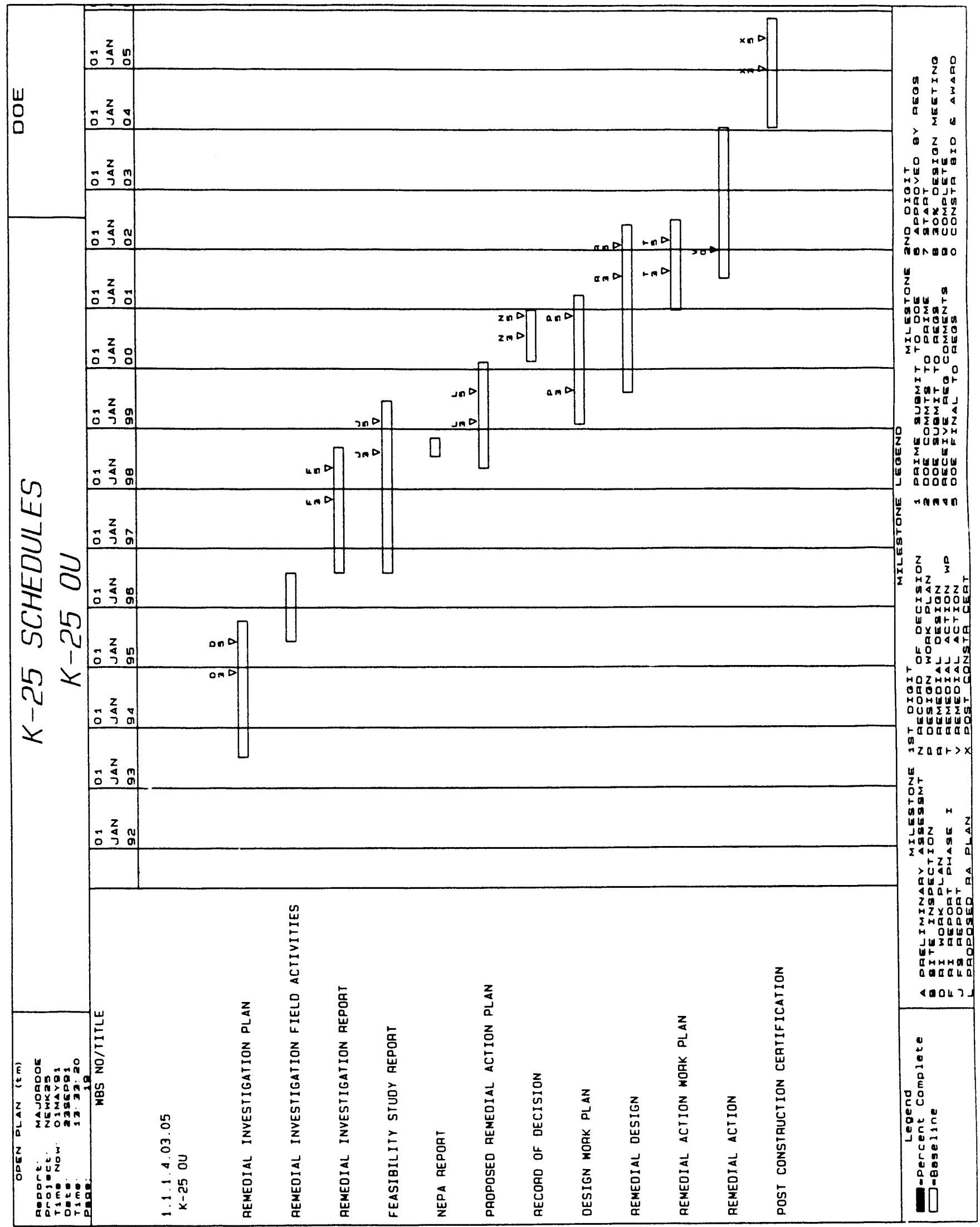




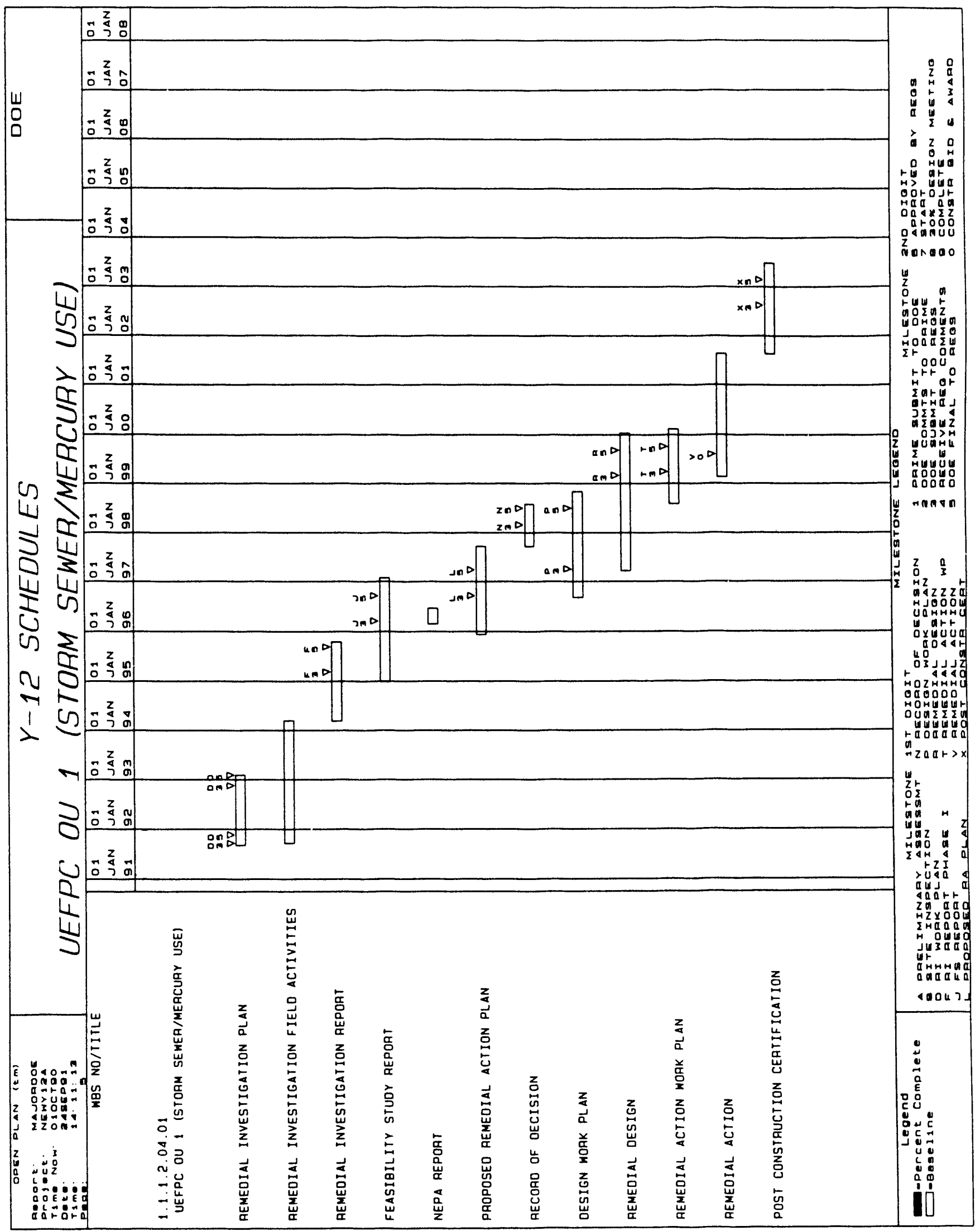


C-35

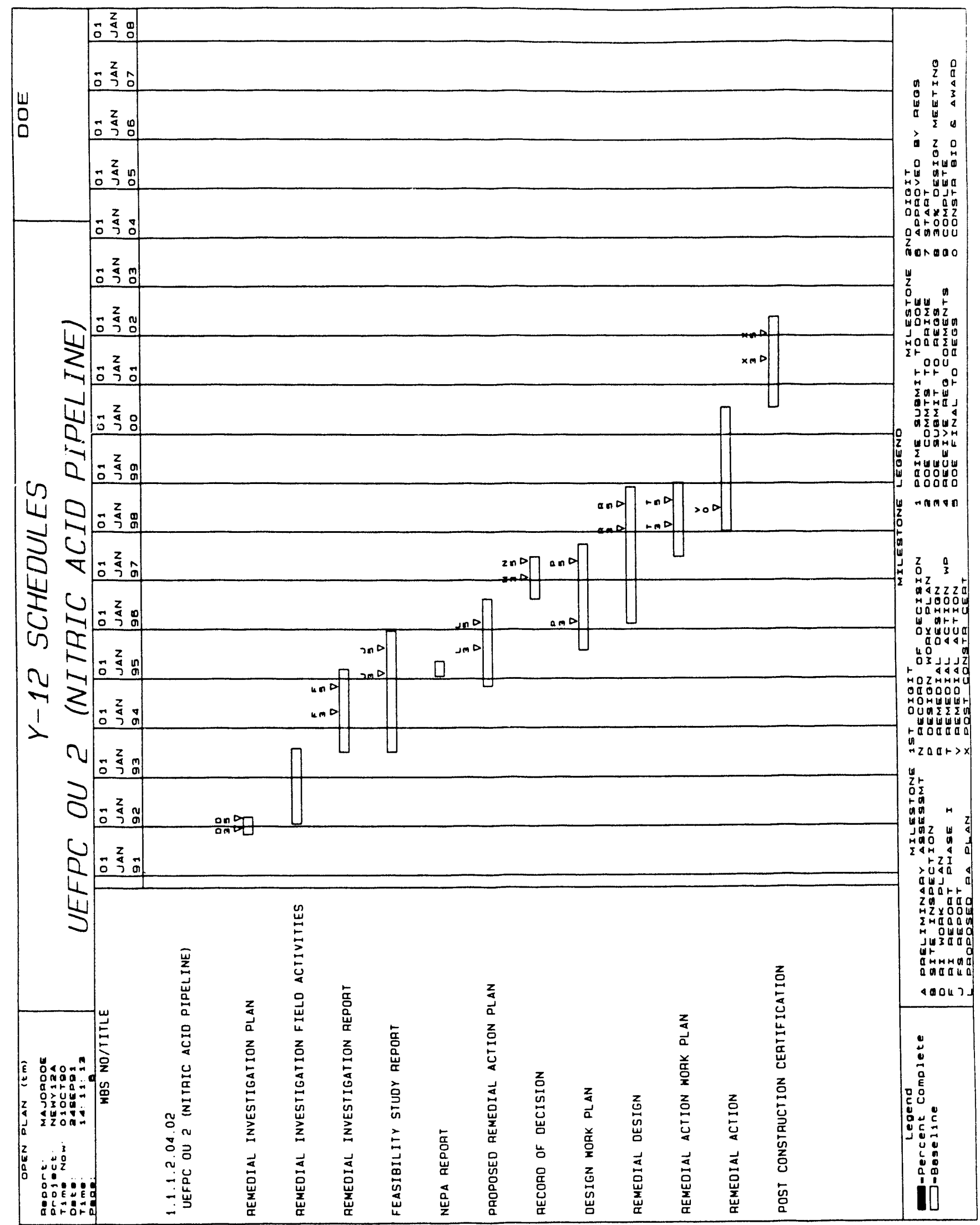




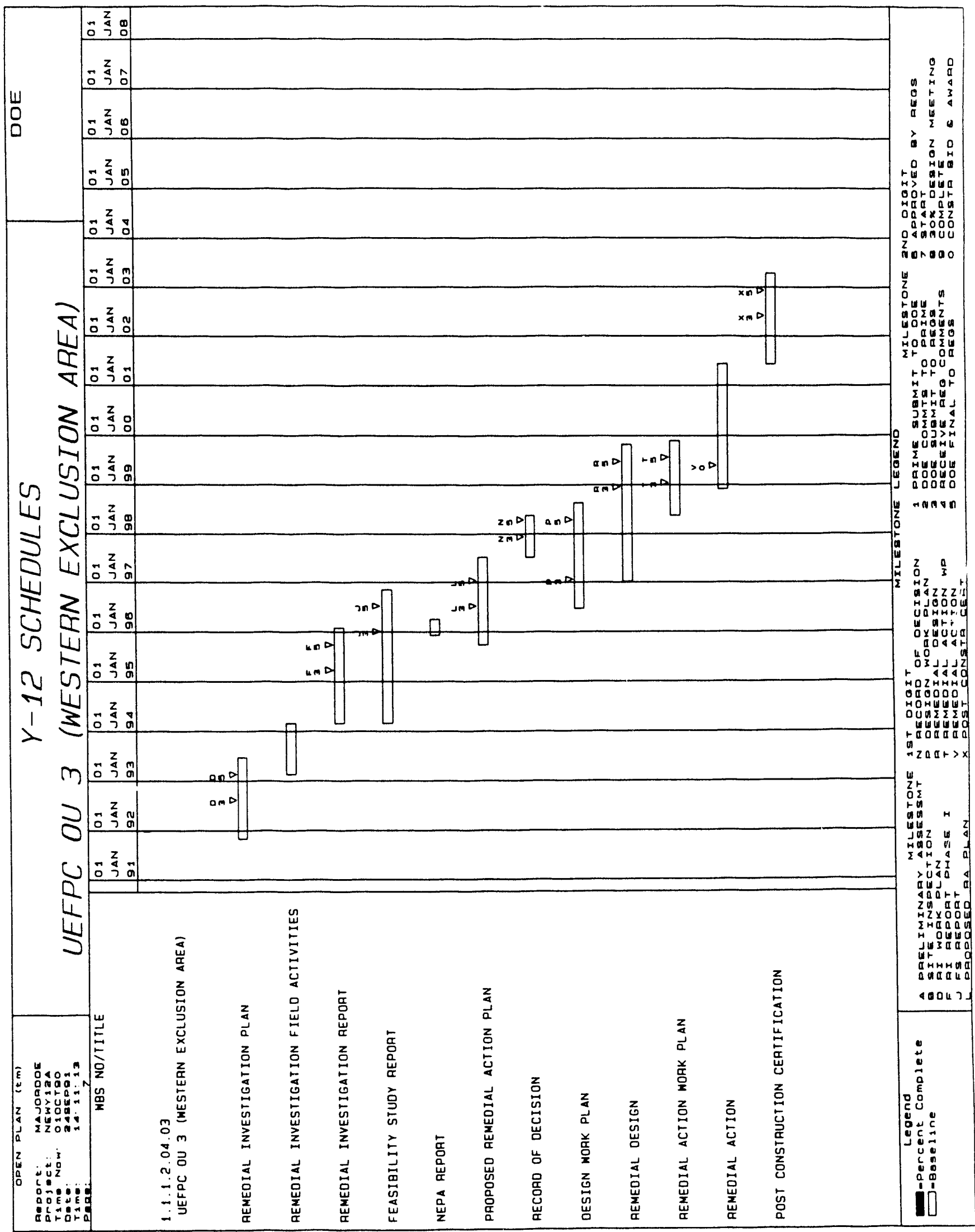




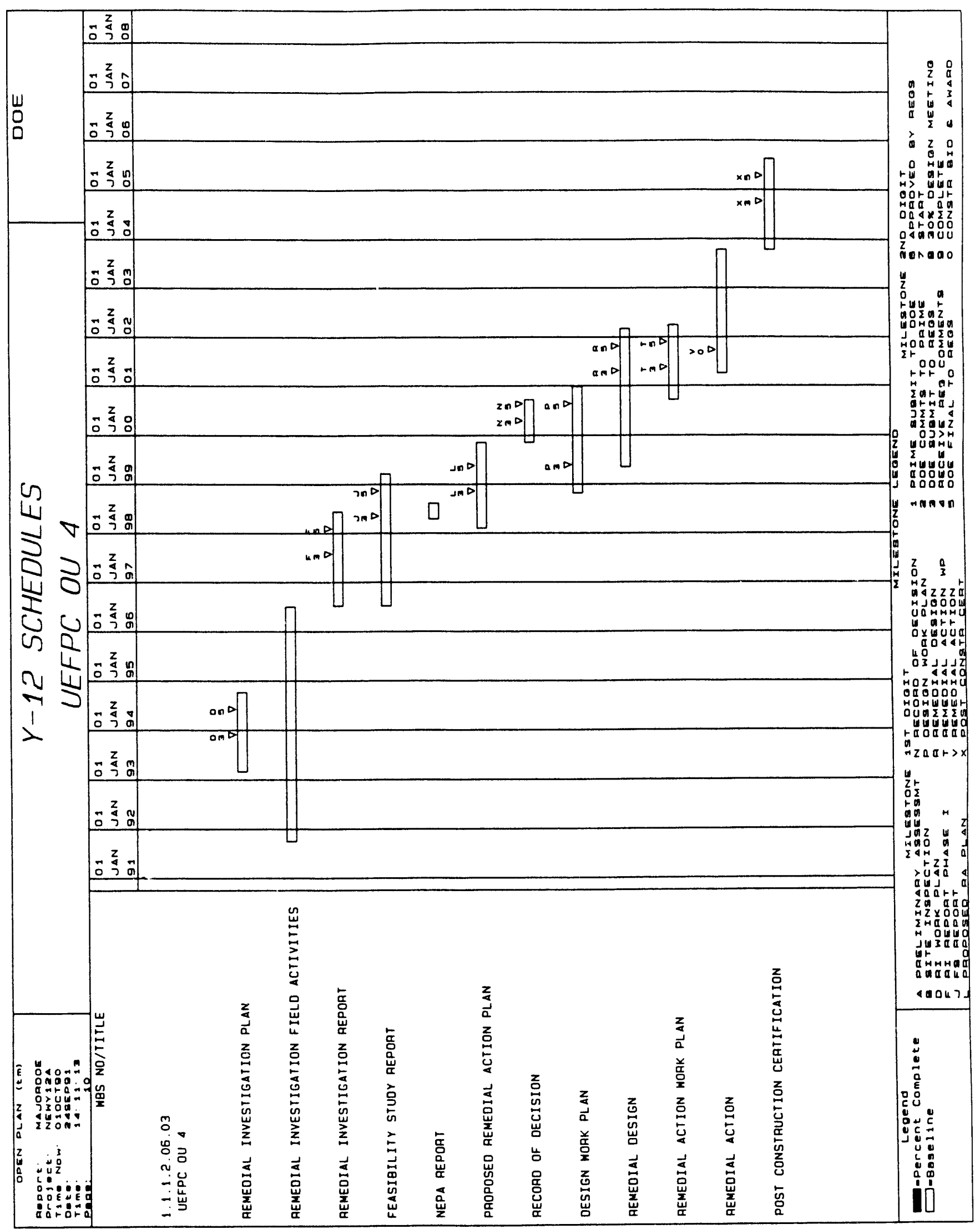




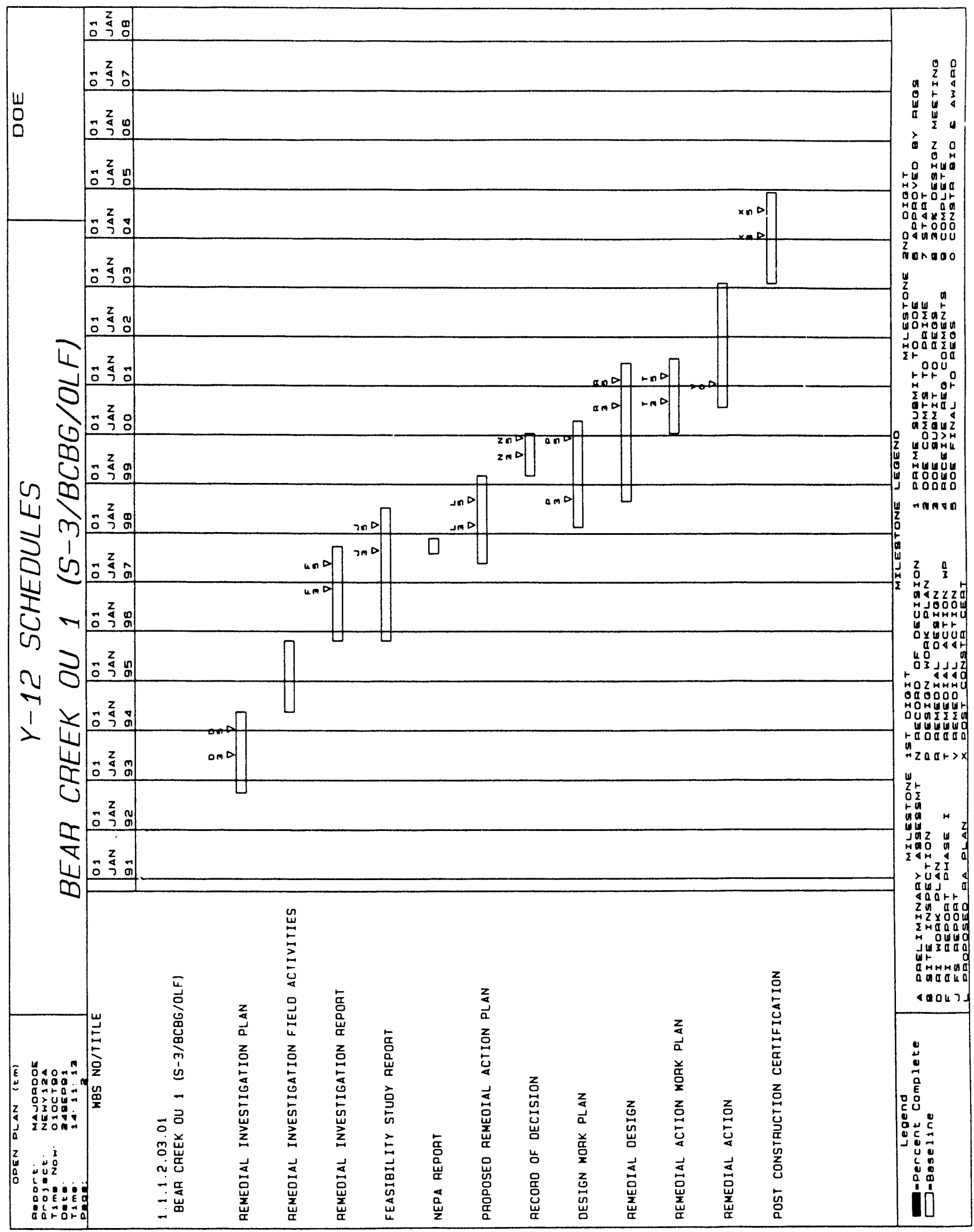




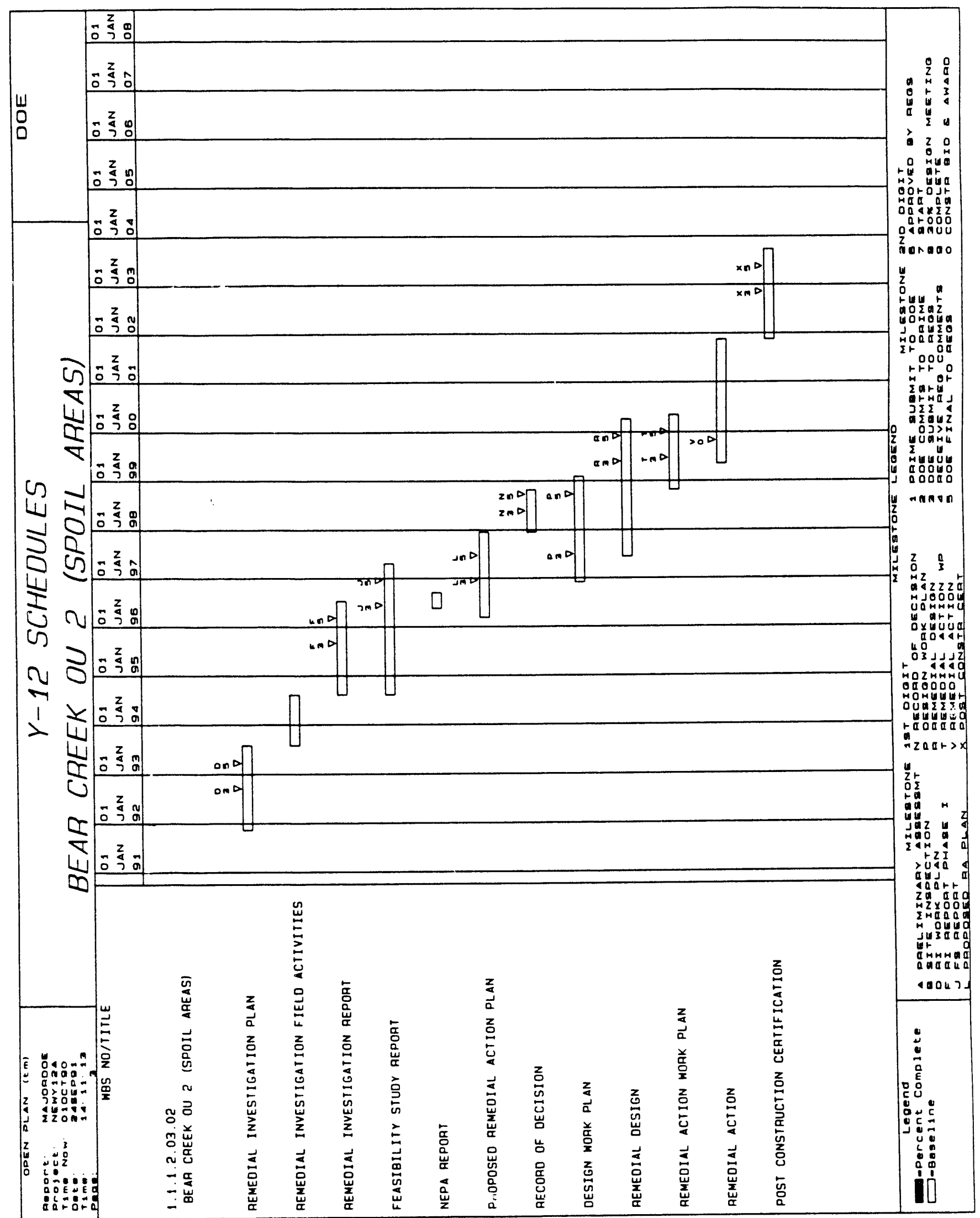




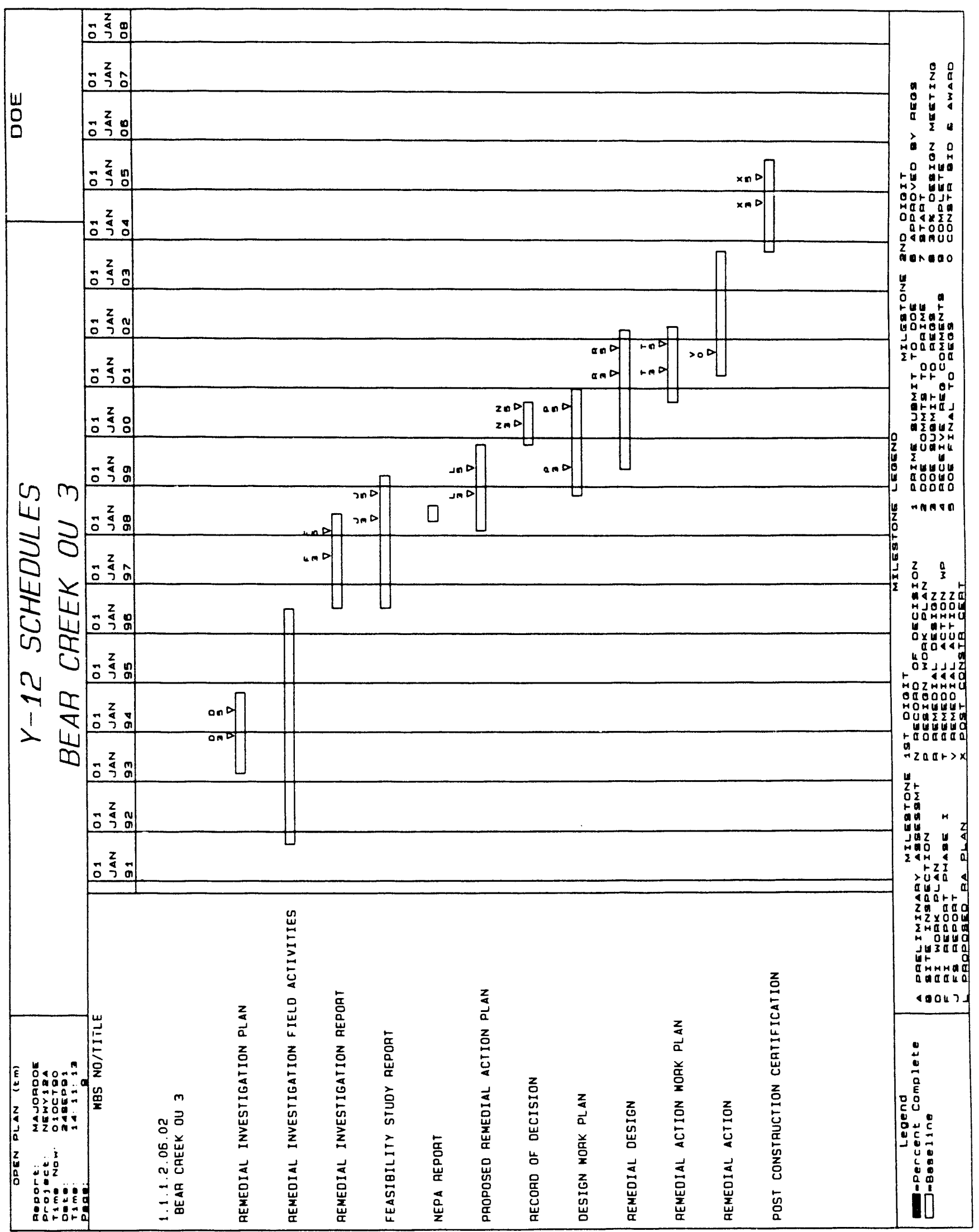




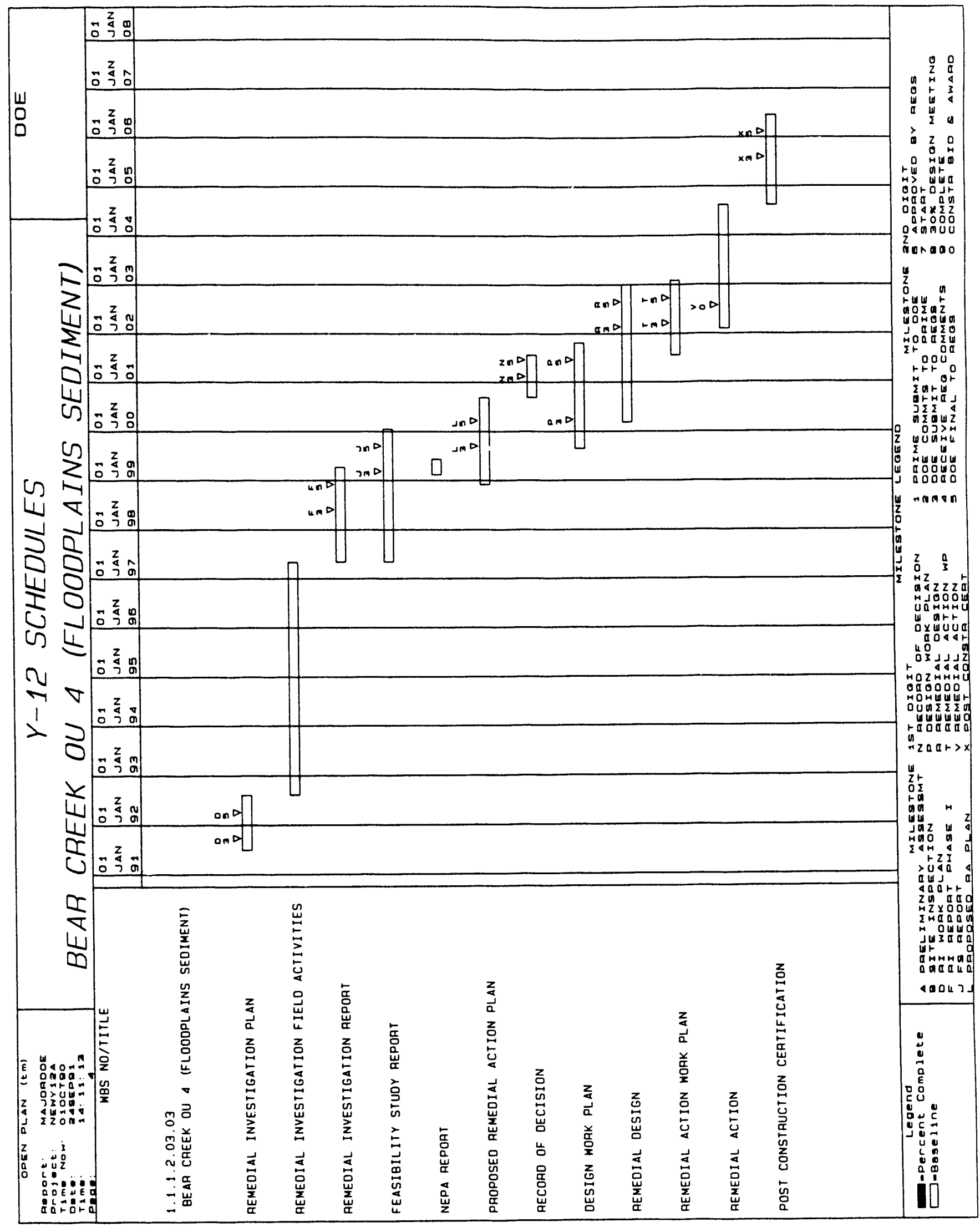


C-42

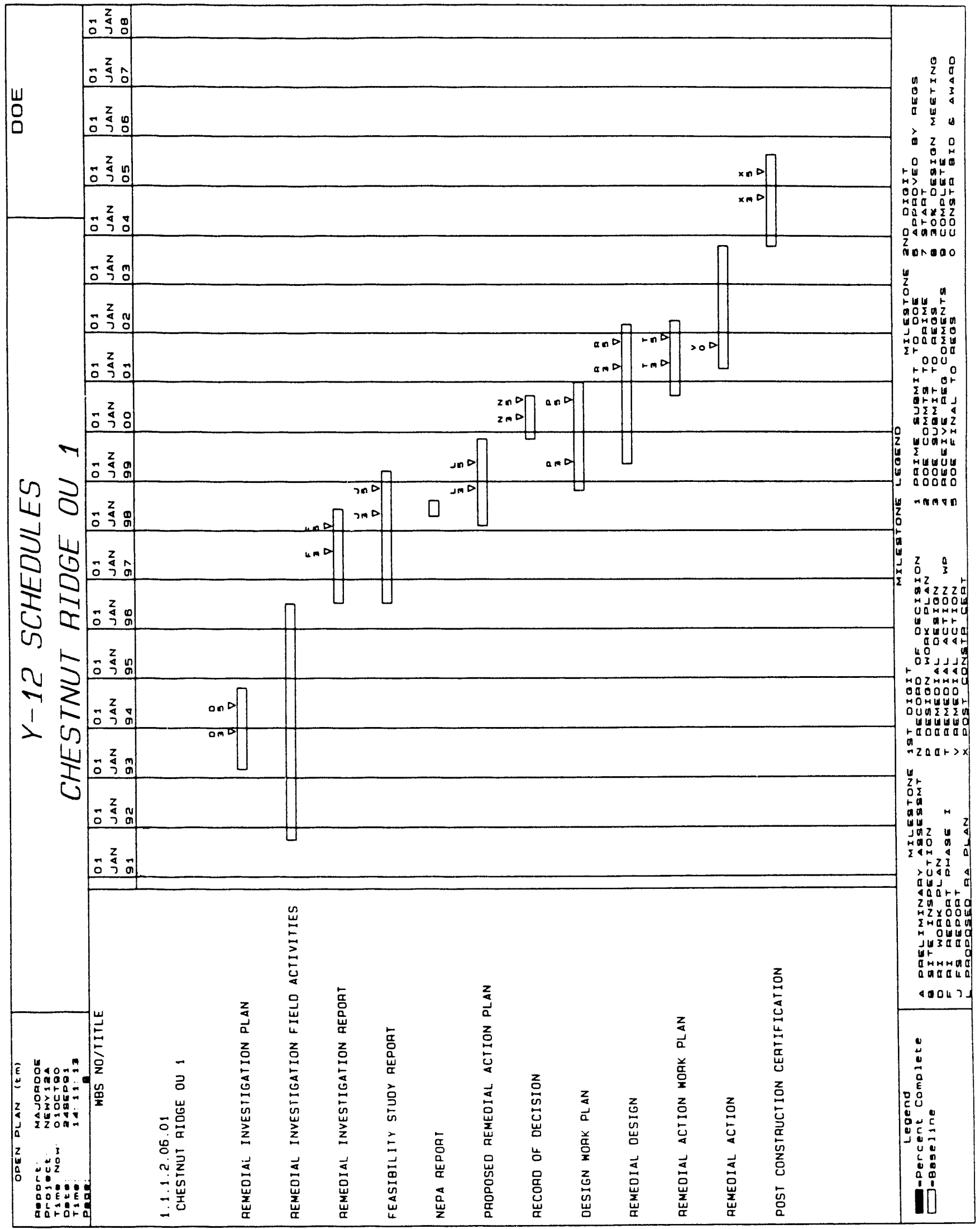




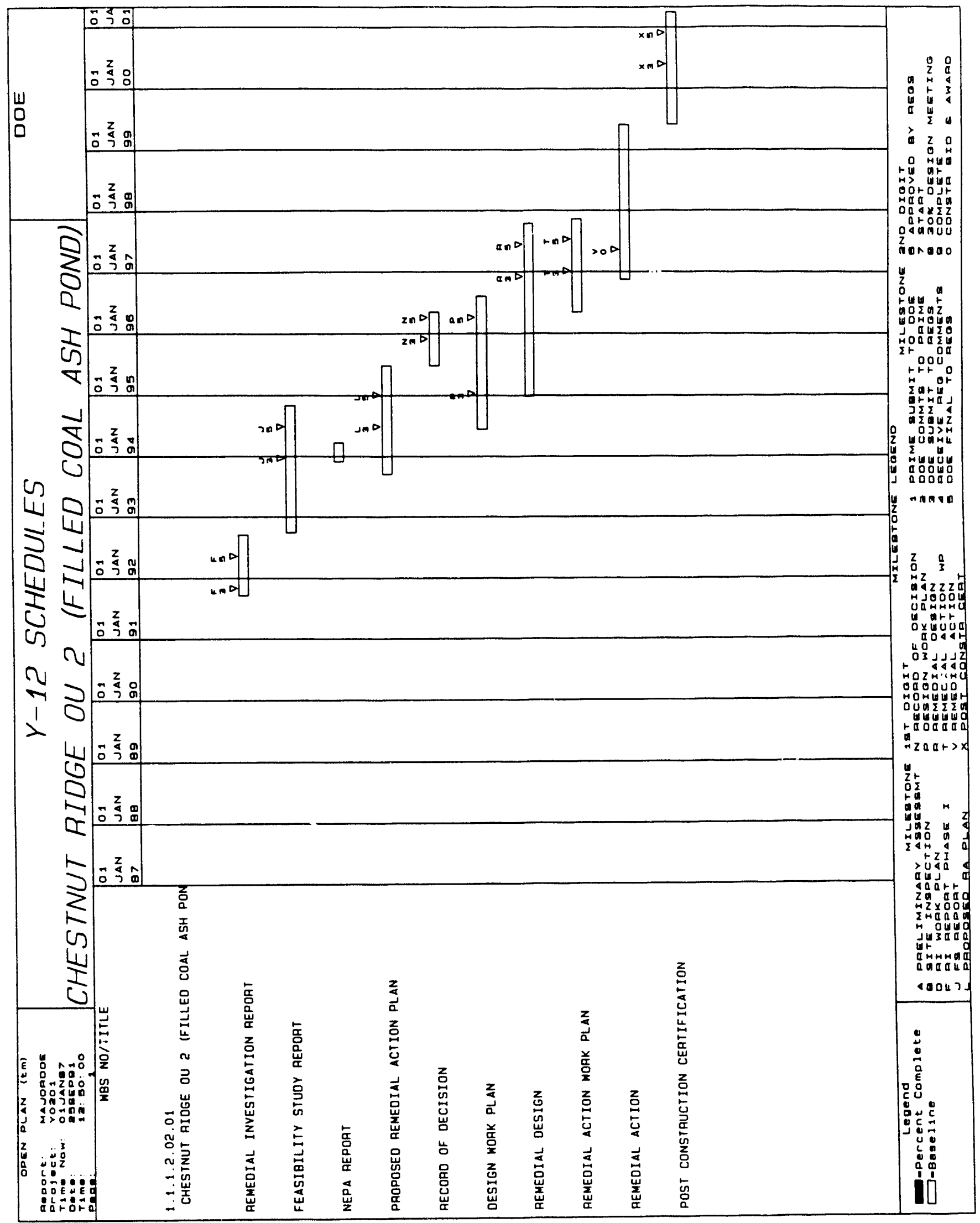




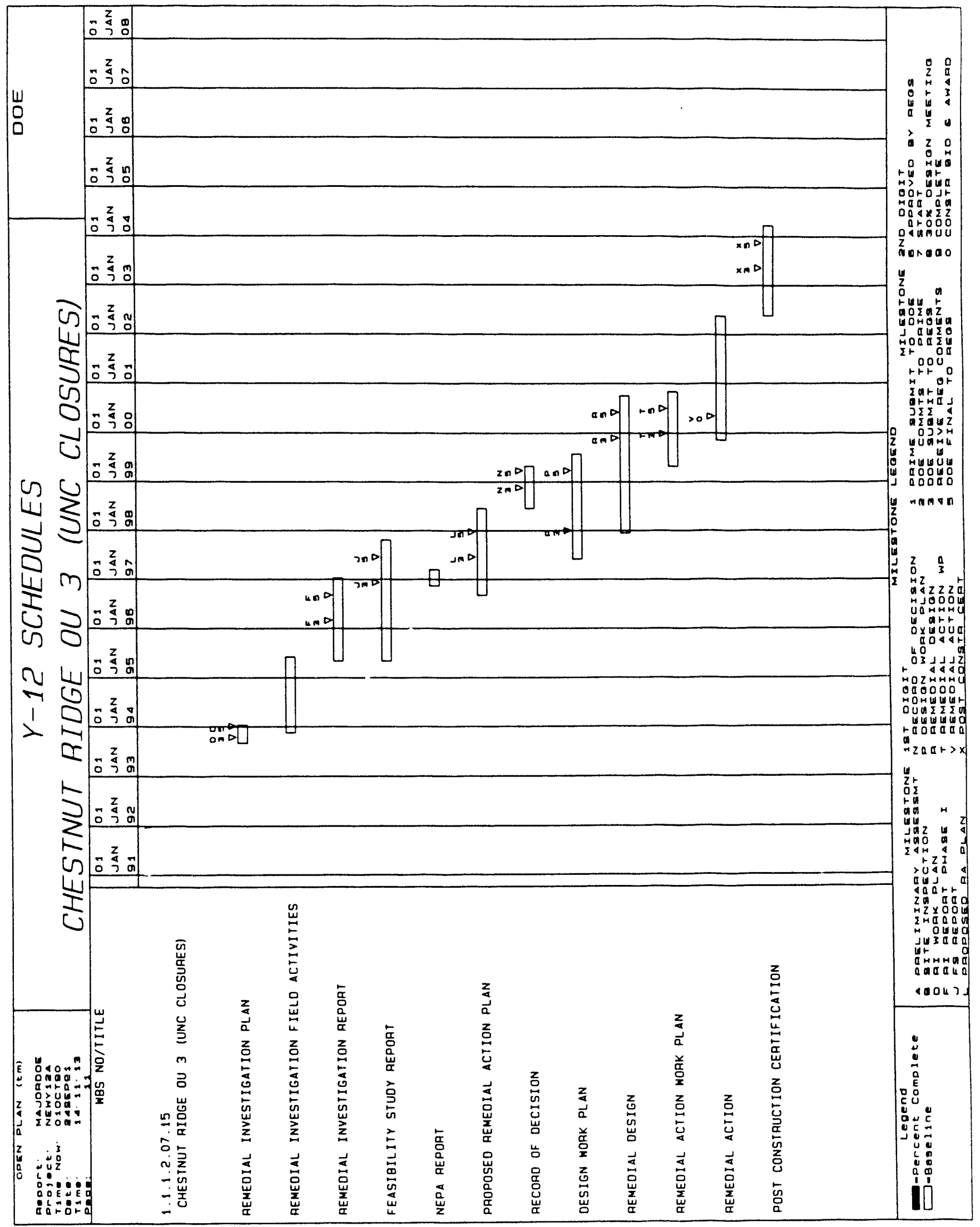




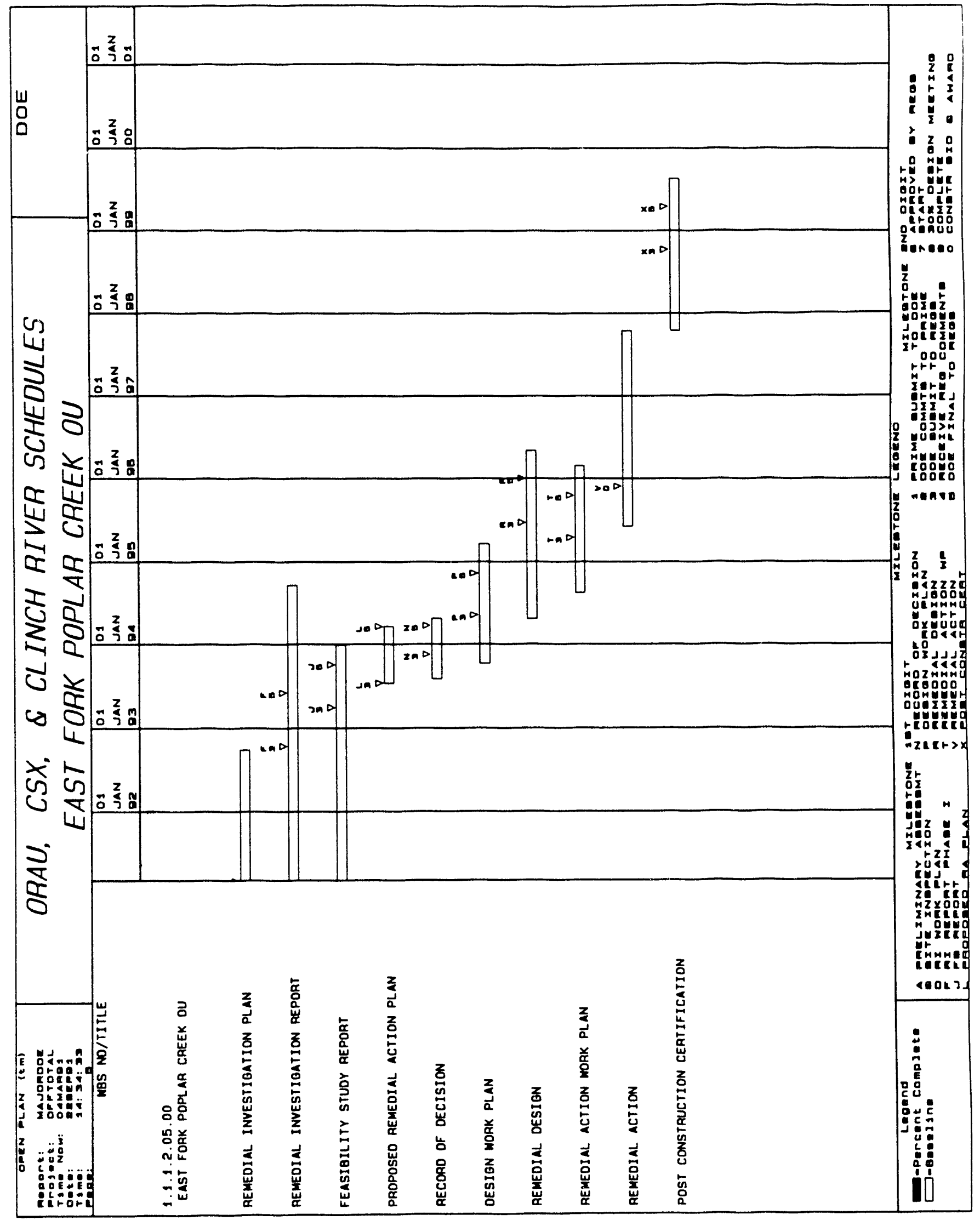




\section{Appendix D \\ MAPS OF OAK RIDGE RESERVATION OPERABLE UNITS}


Appendix E

OAK RIDGE RESERVATION OPERABLE UNITS 


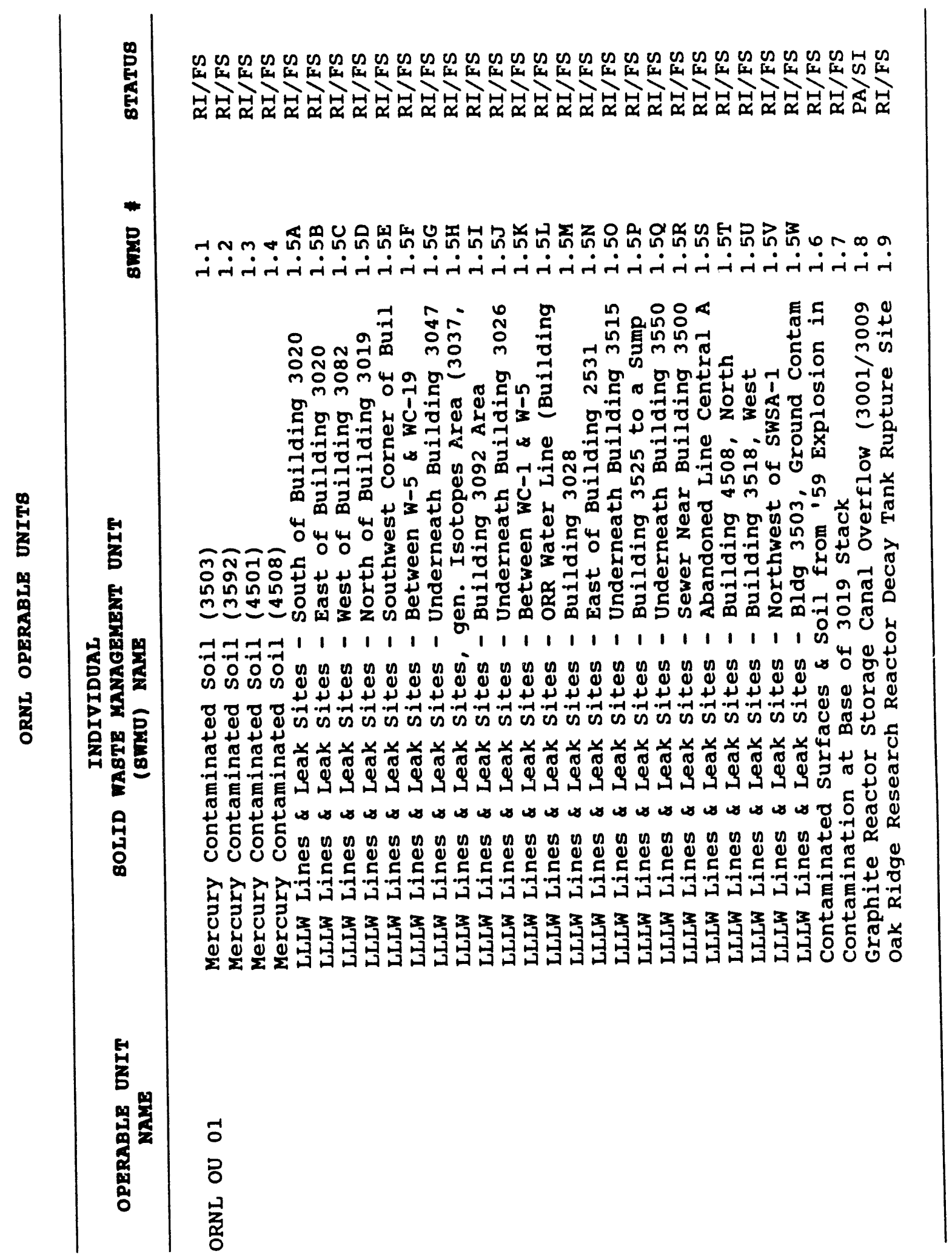




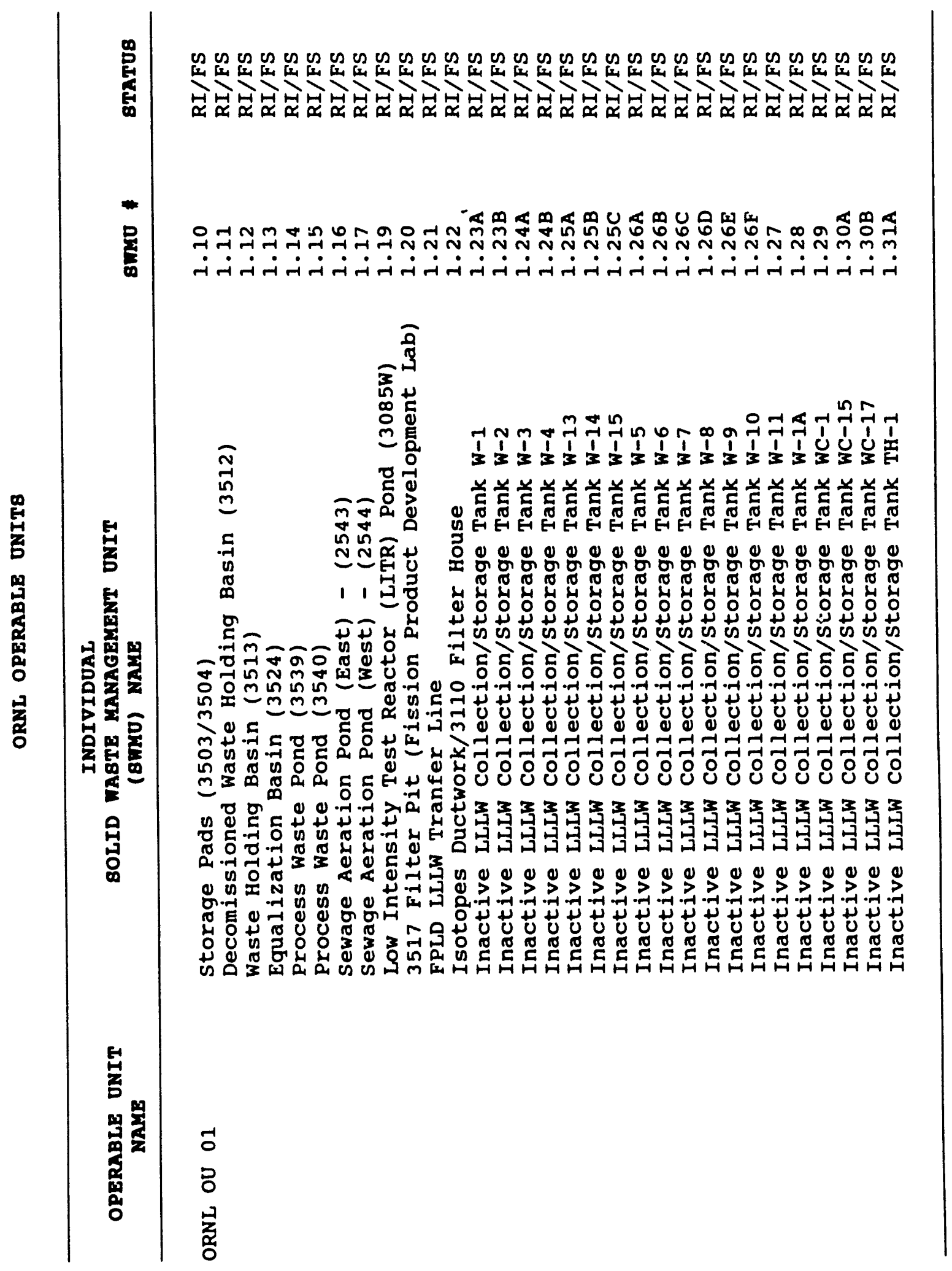




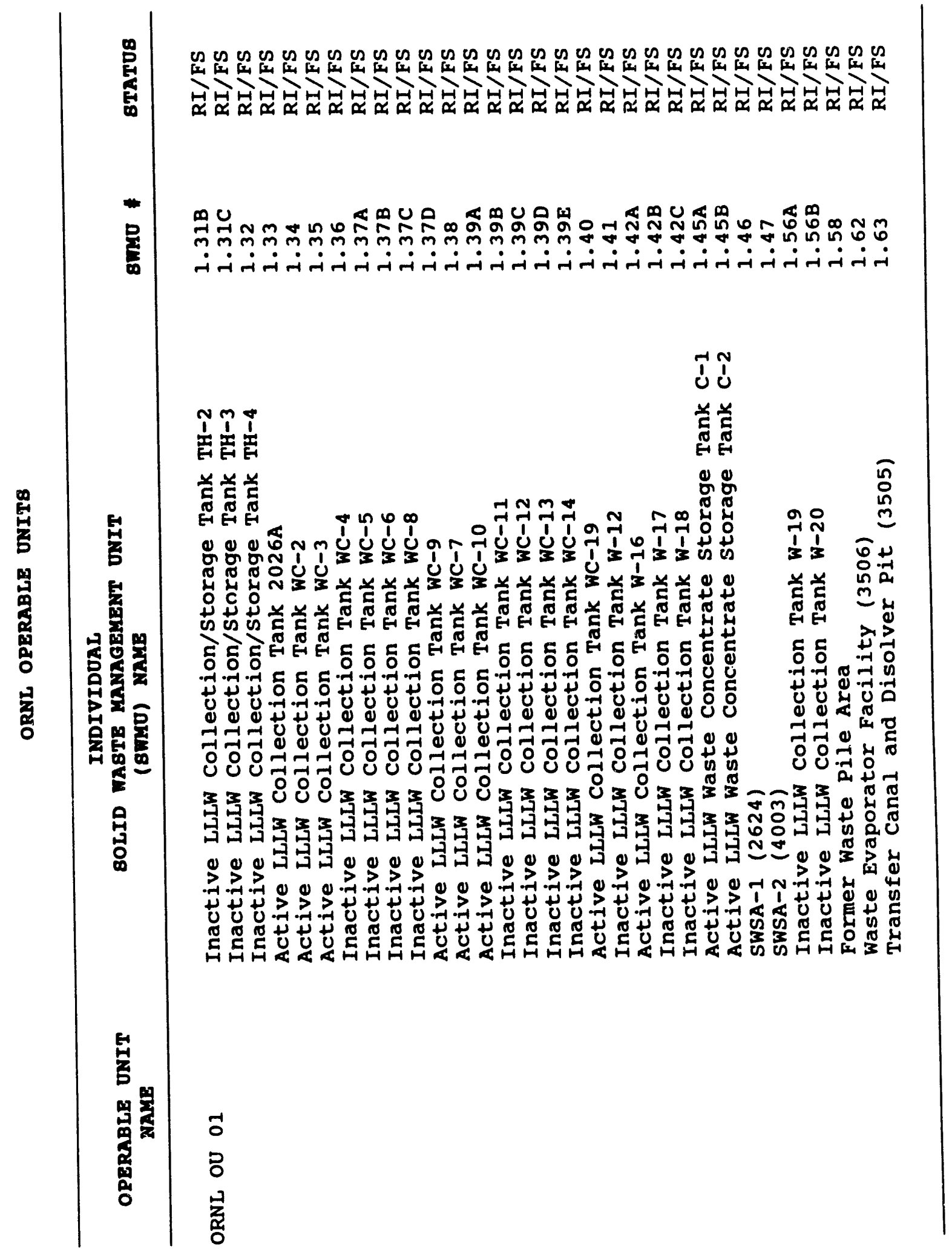


E-6

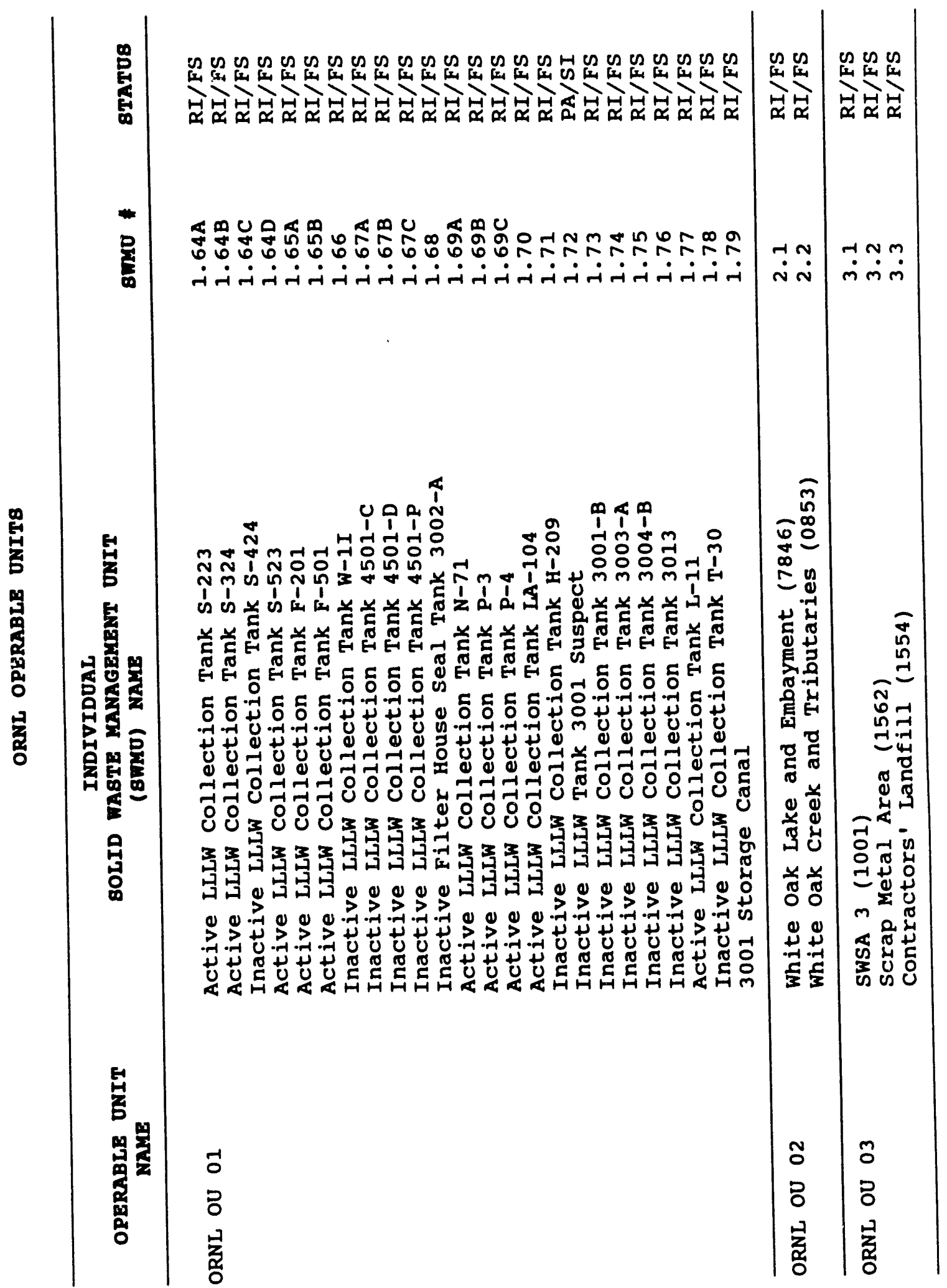




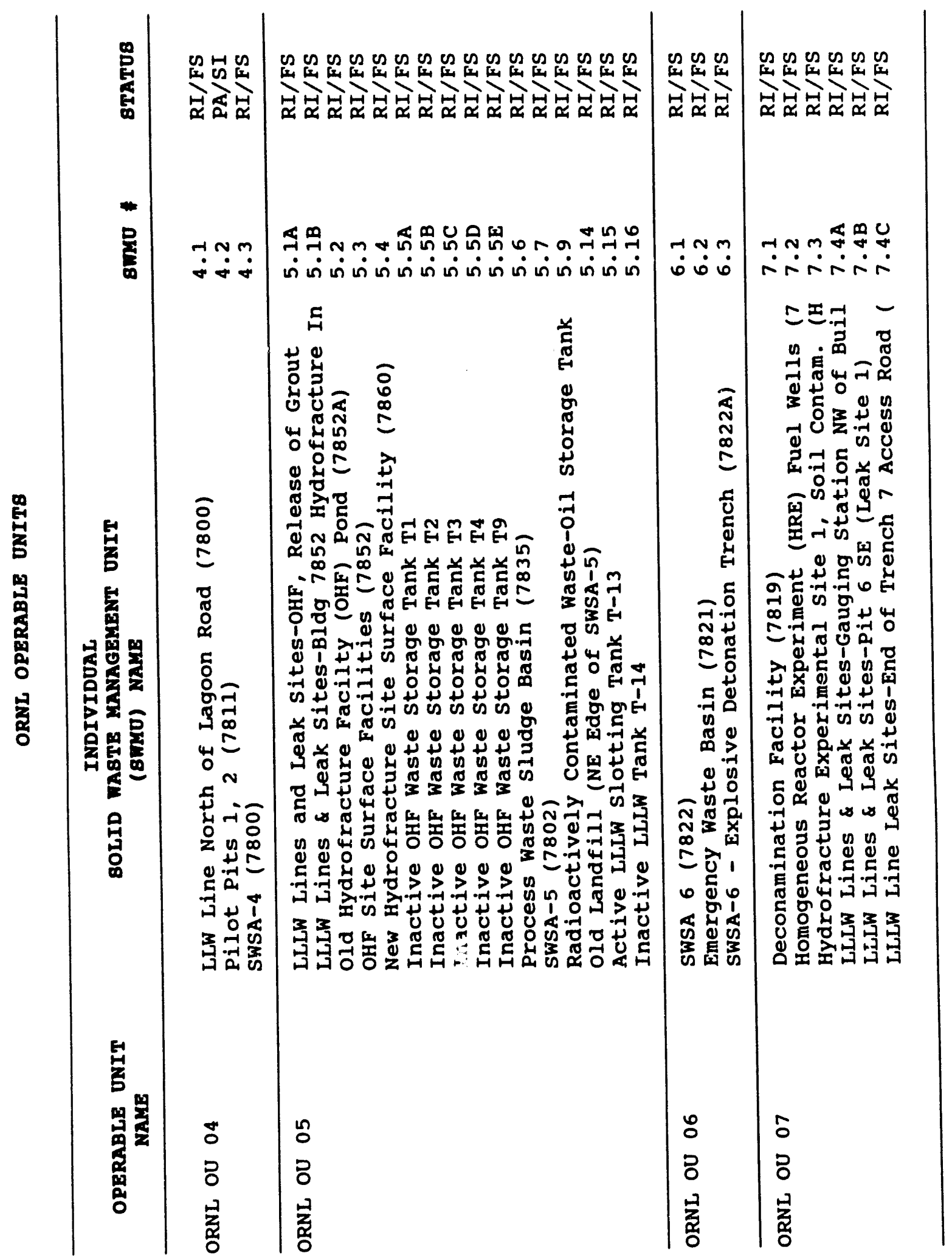




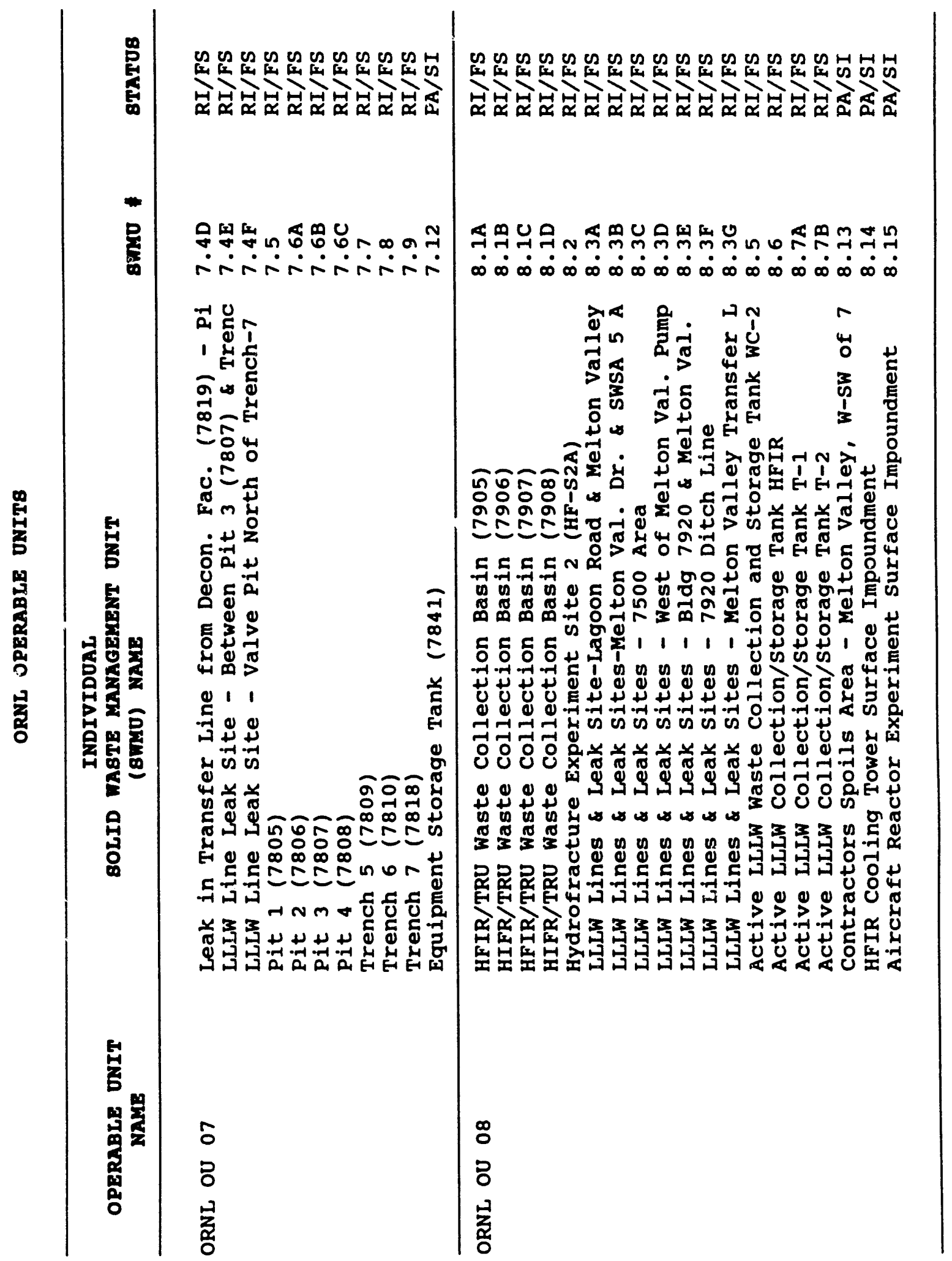




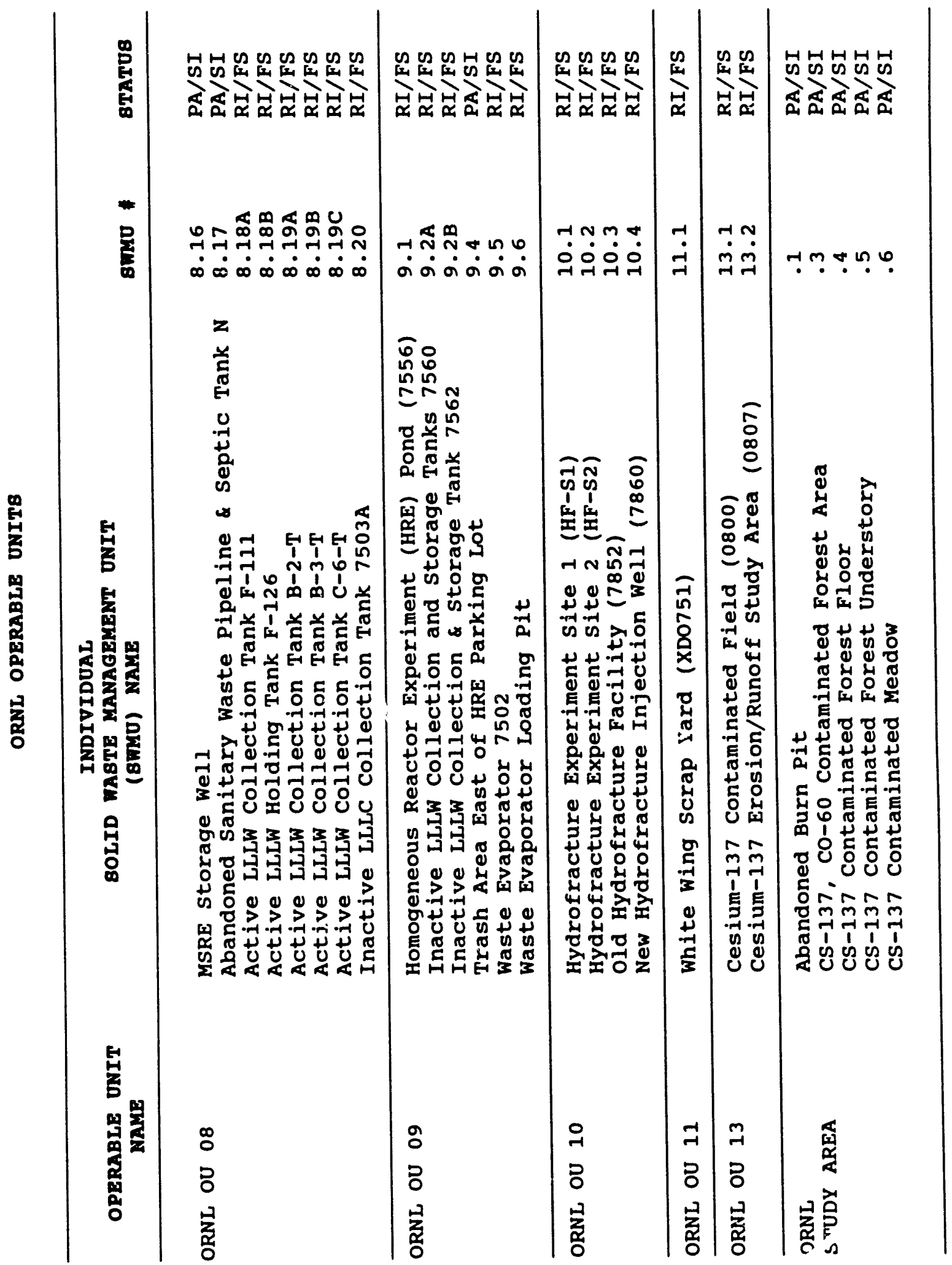




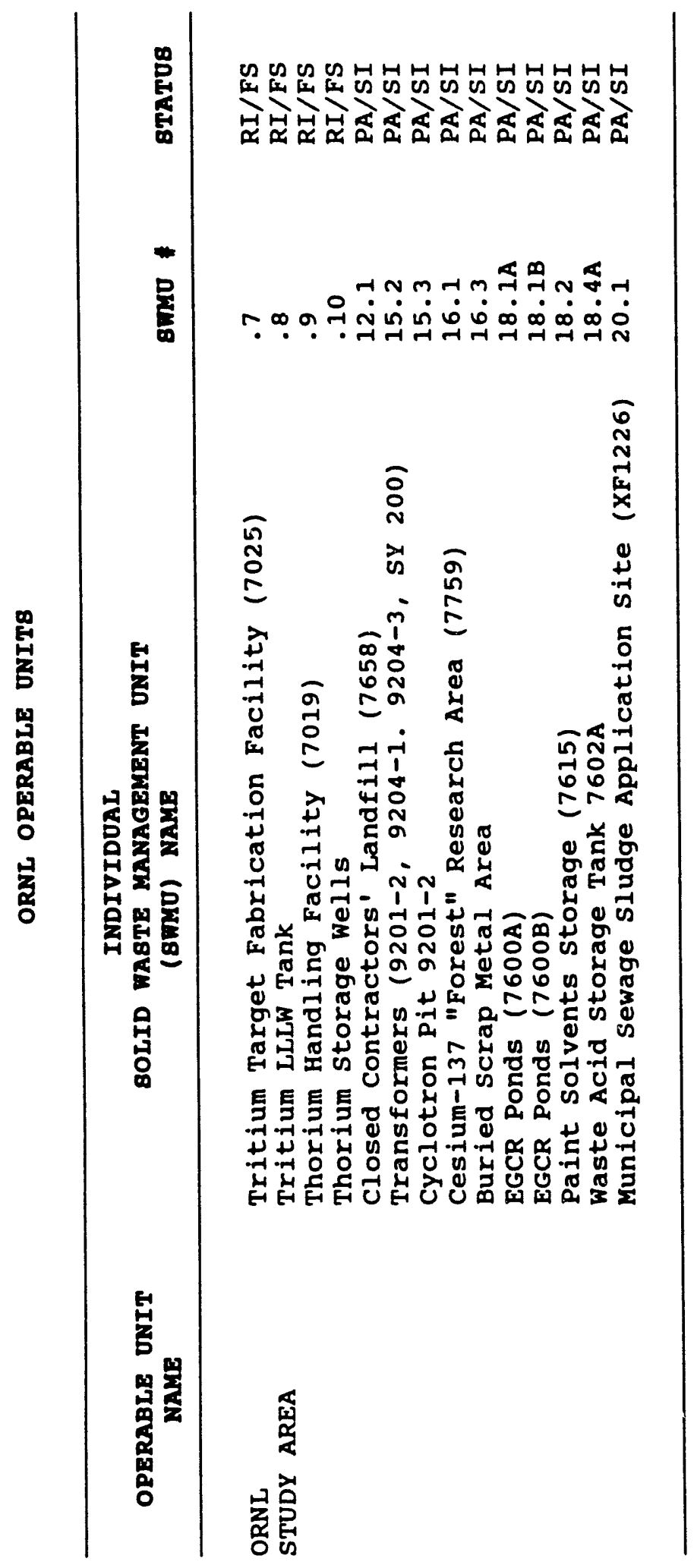




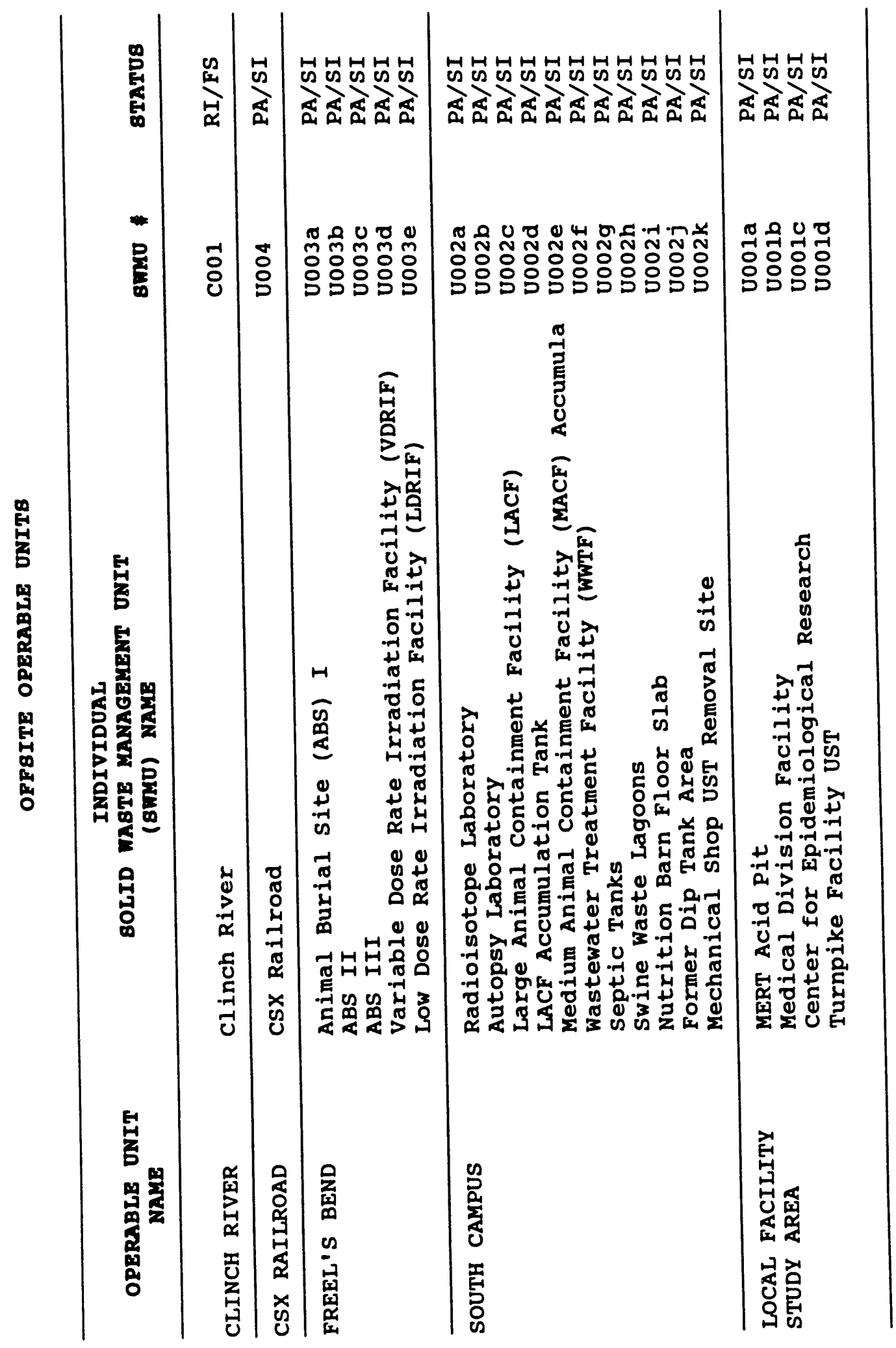




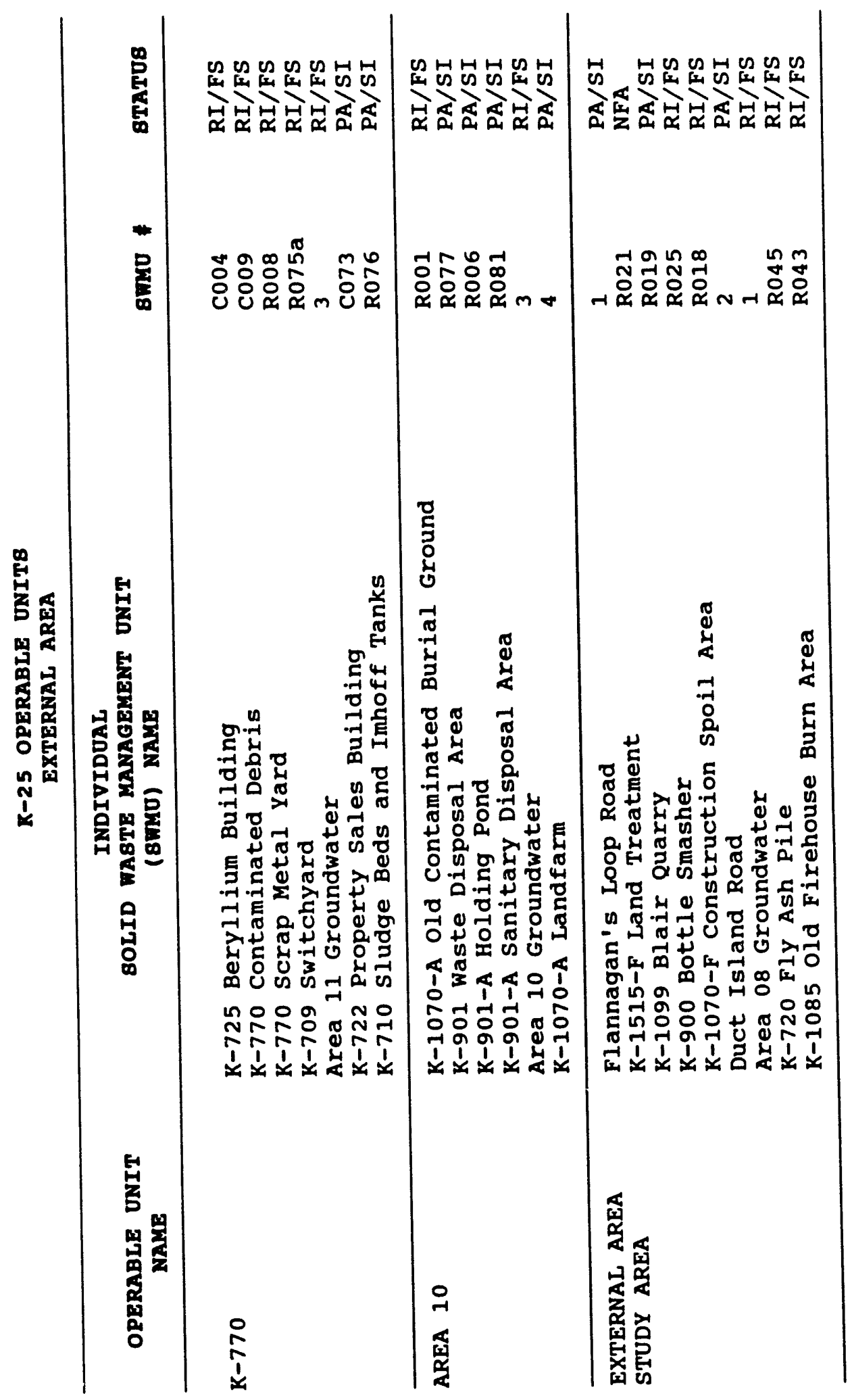




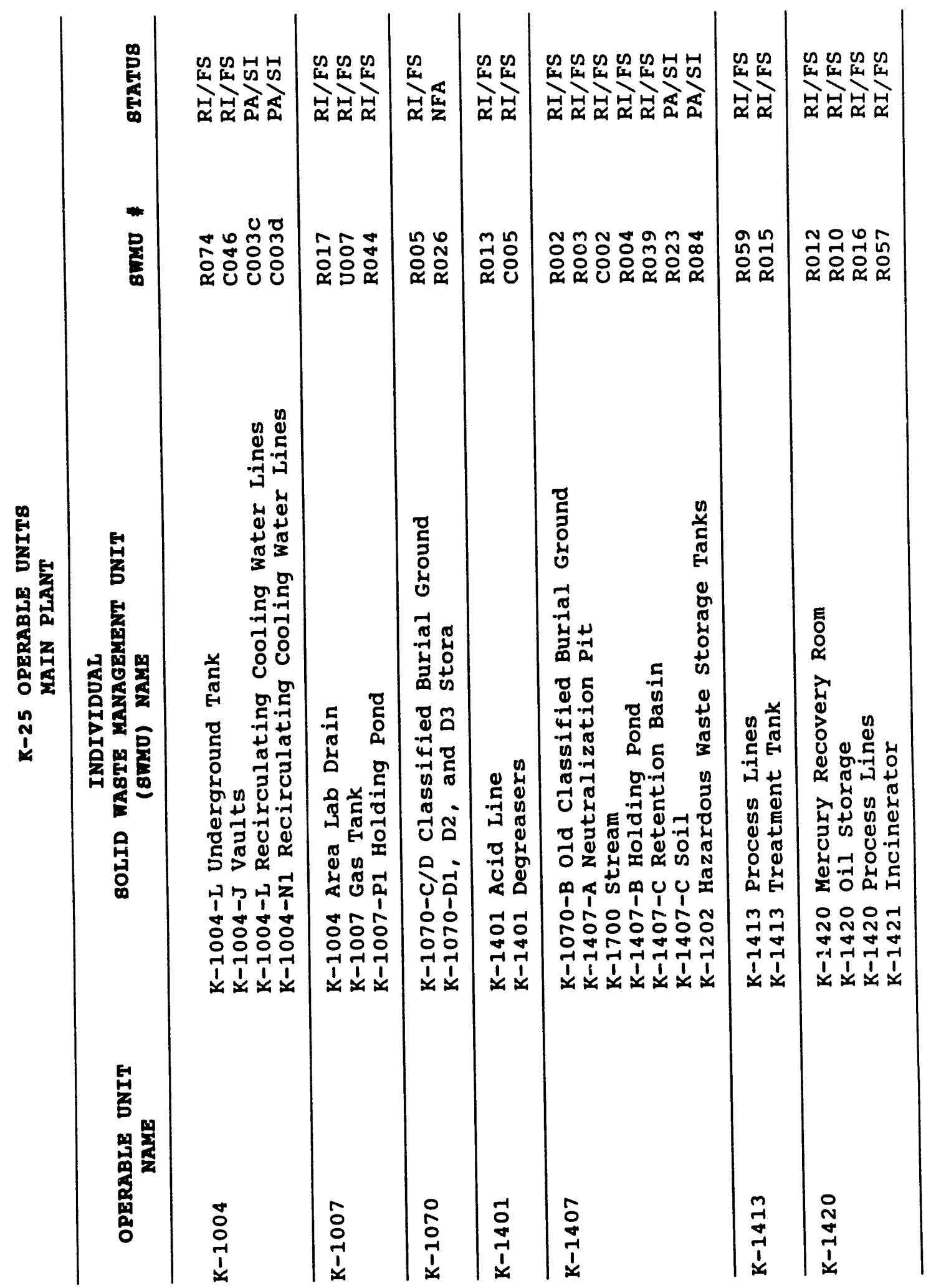


E-14

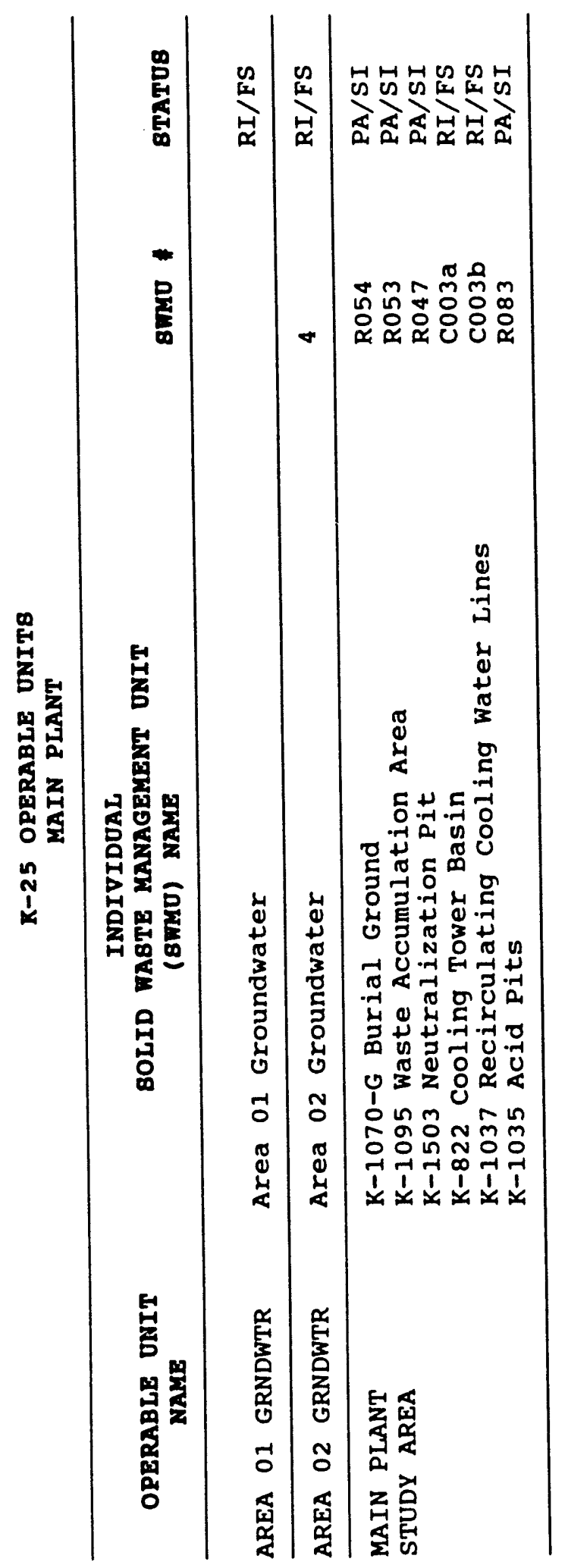


E-15

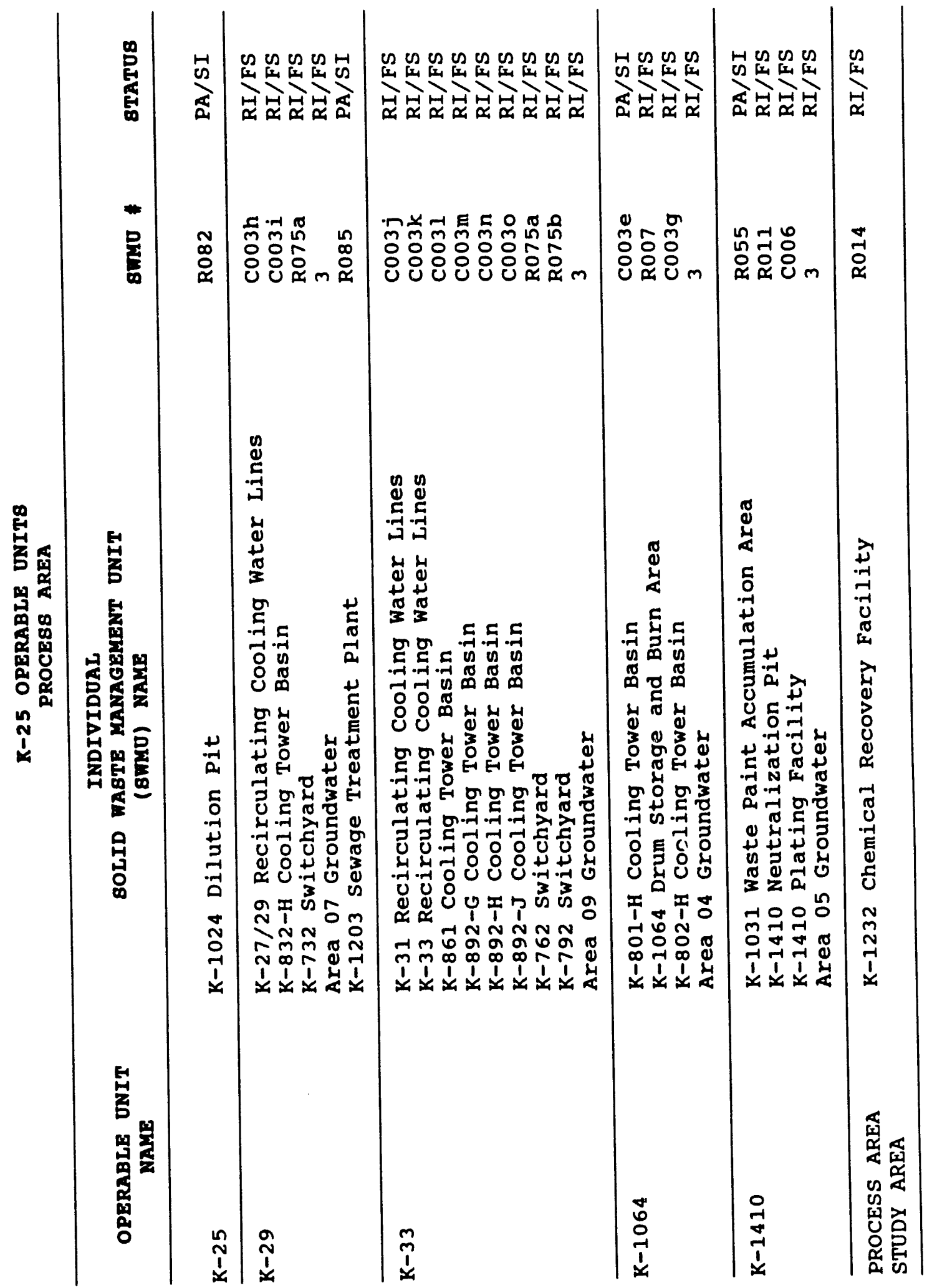




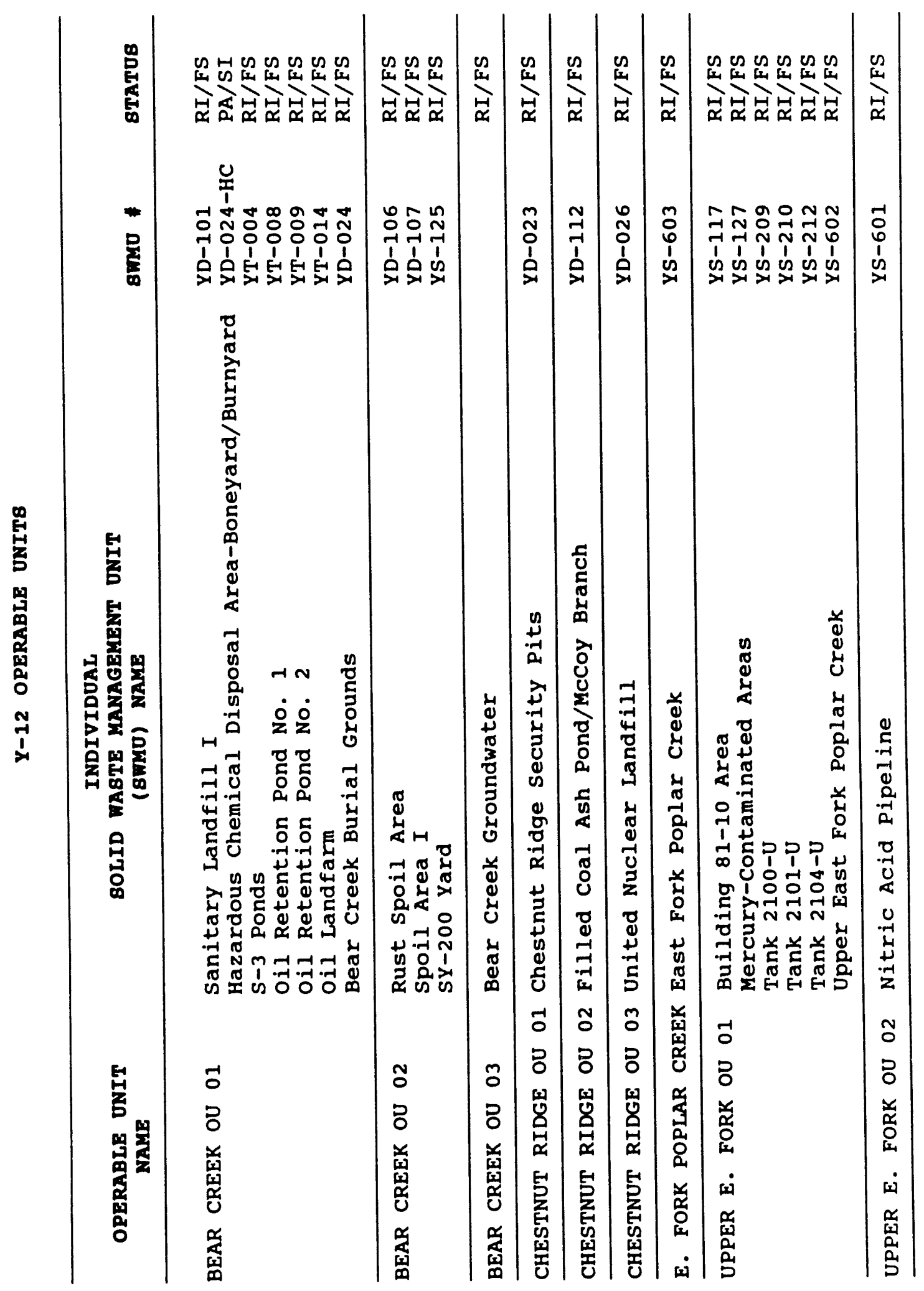


E-17

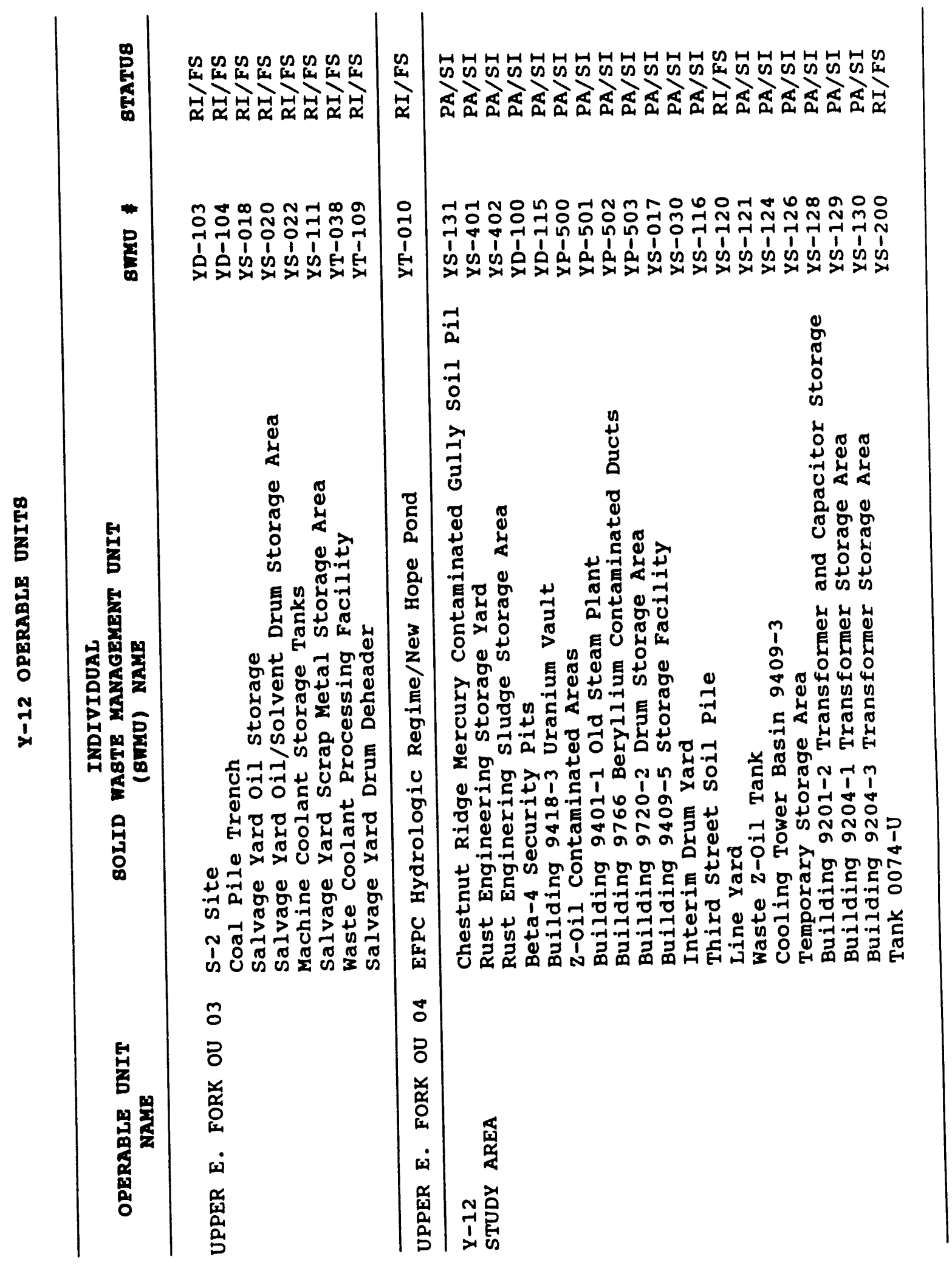




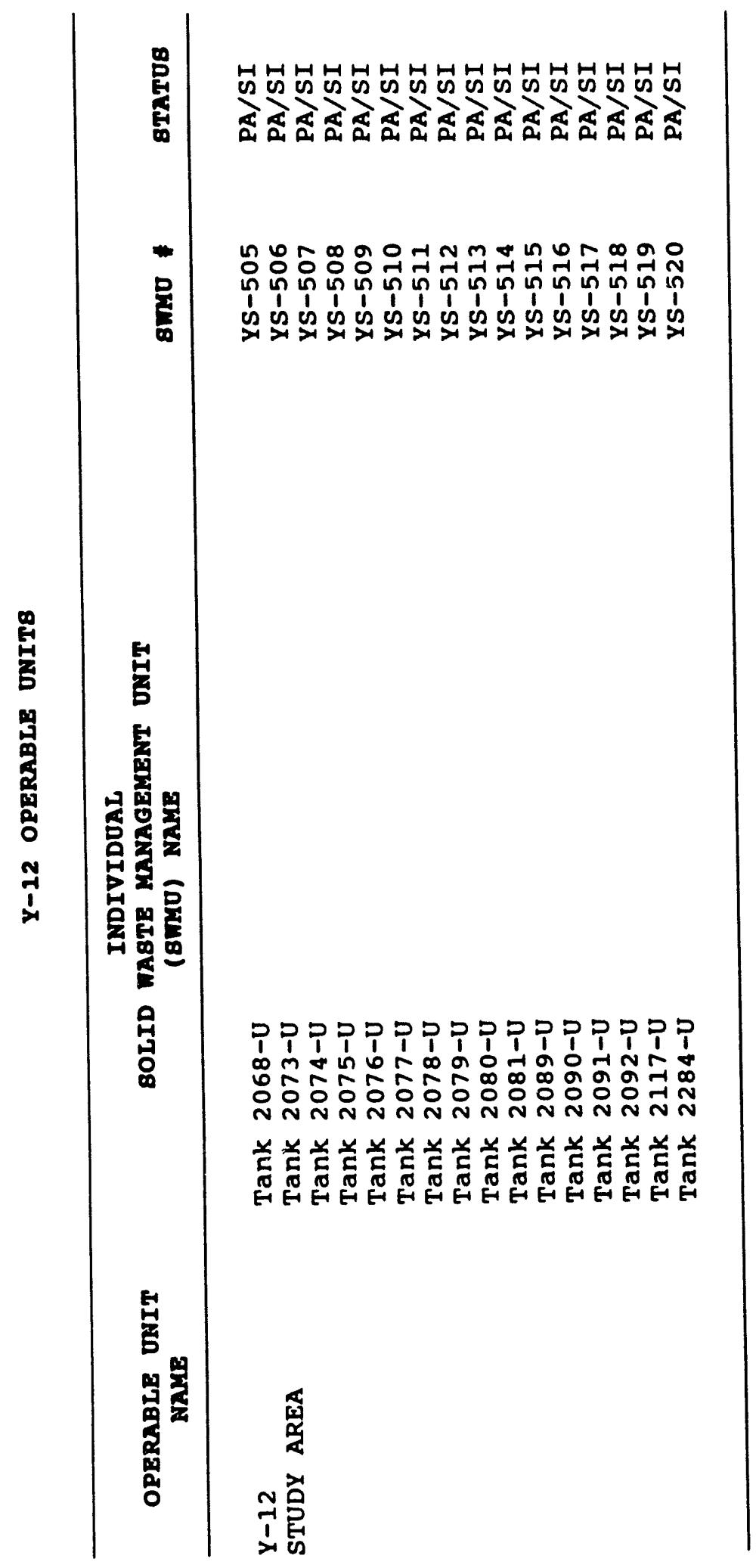



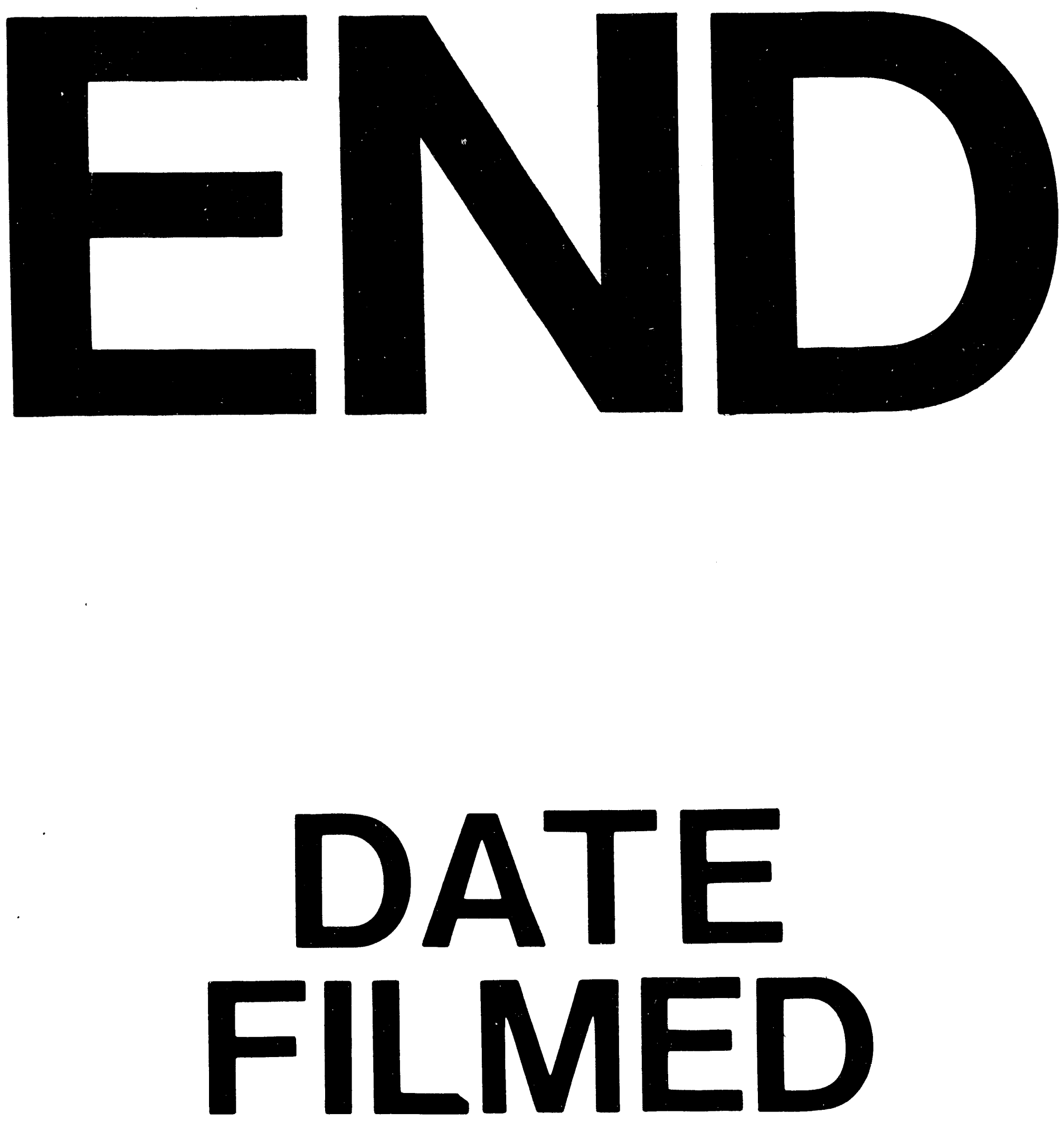

1

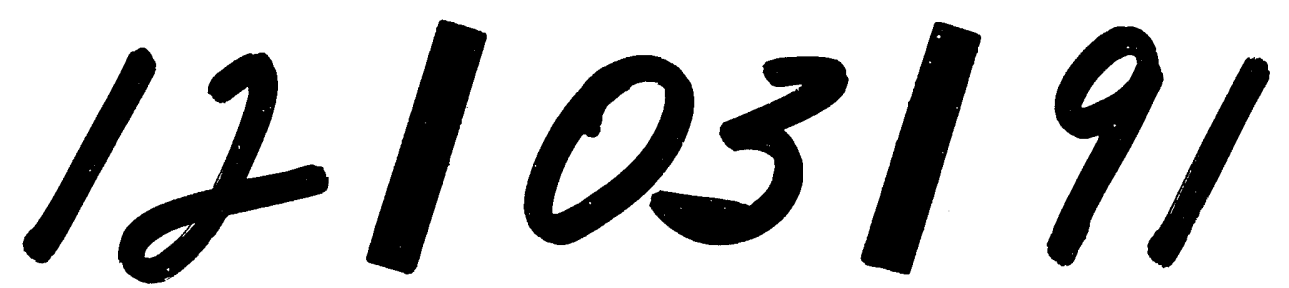


